\title{
PALADYN v1.0, a comprehensive land surface-vegetation-carbon cycle model of intermediate complexity
}

\author{
Matteo Willeit and Andrey Ganopolski \\ Potsdam Institute for Climate Impact Research (PIK), Potsdam, Germany \\ Correspondence to: Matteo Willeit (willeit@pik-potsdam.de)
}

Received: 15 April 2016 - Published in Geosci. Model Dev. Discuss.: 26 April 2016

Revised: 14 September 2016 - Accepted: 3 October 2016 - Published: 28 October 2016

\begin{abstract}
PALADYN is presented; it is a new comprehensive and computationally efficient land surface-vegetationcarbon cycle model designed to be used in Earth system models of intermediate complexity for long-term simulations and paleoclimate studies.

The model treats in a consistent manner the interaction between atmosphere, terrestrial vegetation and soil through the fluxes of energy, water and carbon. Energy, water and carbon are conserved. PALADYN explicitly treats permafrost, both in physical processes and as an important carbon pool. It distinguishes nine surface types: five different vegetation types, bare soil, land ice, lake and ocean shelf. Including the ocean shelf allows the treatment of continuous changes in sea level and shelf area associated with glacial cycles. Over each surface type, the model solves the surface energy balance and computes the fluxes of sensible, latent and ground heat and upward shortwave and longwave radiation. The model includes a single snow layer.

Vegetation and bare soil share a single soil column. The soil is vertically discretized into five layers where prognostic equations for temperature, water and carbon are consistently solved. Phase changes of water in the soil are explicitly considered. A surface hydrology module computes precipitation interception by vegetation, surface runoff and soil infiltration. The soil water equation is based on Darcy's law. Given soil water content, the wetland fraction is computed based on a topographic index. The temperature profile is also computed in the upper part of ice sheets and in the ocean shelf soil.
\end{abstract}

Photosynthesis is computed using a light use efficiency model. Carbon assimilation by vegetation is coupled to the transpiration of water through stomatal conductance. PALADYN includes a dynamic vegetation module with five plant functional types competing for the grid cell share with their respective net primary productivity.

PALADYN distinguishes between mineral soil carbon, peat carbon, buried carbon and shelf carbon. Each soil carbon type has its own soil carbon pools generally represented by a litter, a fast and a slow carbon pool in each soil layer. Carbon can be redistributed between the layers by vertical diffusion and advection. For the vegetated macro surface type, decomposition is a function of soil temperature and soil moisture. Carbon in permanently frozen layers is assigned a long turnover time which effectively locks carbon in permafrost. Carbon buried below ice sheets and on flooded ocean shelves is treated differently. The model also includes a dynamic peat module.

PALADYN includes carbon isotopes ${ }^{13} \mathrm{C}$ and ${ }^{14} \mathrm{C}$, which are tracked through all carbon pools. Isotopic discrimination is modelled only during photosynthesis.

A simple methane module is implemented to represent methane emissions from anaerobic carbon decomposition in wetlands (including peatlands) and flooded ocean shelf.

The model description is accompanied by a thorough model evaluation in offline mode for the present day and the historical period.

\section{Introduction}

Land surface models (LSMs) represent an essential component of Earth system models (ESMs) of different complexity. Currently, LSMs simulate the interaction between atmosphere, vegetation, land surface and upper soil through the fluxes of energy, water and carbon. Modern LSMs are the result of a gradual convergence of initially separate modelling 
approaches: climate, carbon cycle and vegetation dynamics models (e.g. Pitman, 2003; Sellers et al., 1997).

In the earlier climate models, very simple land surface schemes with bucket hydrology and without explicit vegetation representation were used (Manabe, 1969). The secondgeneration LSMs (Sellers et al., 1997) simulated soil temperature and moisture in several layers and the water and energy exchange between the land surface and the atmosphere were mediated by vegetation represented as a big leaf (e.g. Deardorff, 1978; BATS, Dickinson et al., 1986; and SiB, Sellers et al., 1986). This step was required because biological processes play a major role in controlling evapotranspiration. In second-generation LSMs, the behaviour of leaf stomata, which controls the rate of transpiration of water from plants, was represented based on empirical relations with climate (e.g. Jarvis, 1976). The third generation of LSMs included additionally a mechanistic representation of photosynthesis (Farquhar et al., 1980; Collatz et al., 1991) which could then directly be related to stomatal conductance used to compute transpiration (Ball et al., 1987; Leuning, 1995).

Terrestrial biogeochemical models followed a separate line of development. These models were designed to simulate the exchanges of carbon between the atmosphere and terrestrial ecosystems for a given climate and geographic vegetation distribution (e.g. Raich et al., 1991; Melillo et al., 1993; Running and Coughlan, 1988; Running and Gower, 1991; Foley, 1994).

Equilibrium biogeography models were developed alongside terrestrial carbon cycle models to simulate the global vegetation distribution for given climatic conditions (Woodward, 1987; Prentice et al., 1992; Haxeltine and Prentice, 1996b; Neilson, 1995). However, equilibrium models do not simulate the processes of plant growth, competition and mortality that govern the dynamics of vegetation changes. Global dynamic vegetation models have been developed for this purpose (Haxeltine and Prentice, 1996b; Sitch et al., 2003; Cox, 2001; Friend et al., 1997; Foley et al., 1996; Woodward et al., 1998; Brovkin et al., 1997).

Since it was shown that climate-vegetation feedbacks may be important, the first attempts to incorporate interactive vegetation into climate models were made (Henderson-Sellers, 1993; Claussen, 1994). While during the 1990s and 2000s climate models and then Earth system models based on coupled general circulation models (GCMs) remained too expensive to perform long-term simulations, a new class of models - Earth system models of intermediate complexity (EMICs, Claussen et al., 2002) - emerged. The EMIC CLIMBER-2 (Petoukhov et al., 2000; Ganopolski et al., 2001) was one of the first Earth system models which included both terrestrial carbon cycle and vegetation dynamics based on VECODE (Brovkin et al., 1997, 2002) and has been also used to estimate the strength of the climate-vegetation feedback (Willeit et al., 2014b) and the carbon cycle feedback (Willeit et al., 2014a). Later, similar and more comprehensive vegetation models were incorporated in both com- plex and intermediate complexity ESMs (e.g. Cox, 2001; Brovkin et al., 2009; Arora and Boer, 2006; Krinner et al., 2005; Sato et al., 2007).

A limitation of previous land surface modelling approaches is that different model components are not necessarily consistent because initially they were developed as stand-alone models. Additionally, initially LSMs have been developed with the intention to capture the processes which are important for climate change projections on the timescales of centuries, thus missing processes which might play an important role on longer timescales. This was fully justified by the fact that complex ESMs were and are still too computationally expensive to be used on much longer timescales, such as for simulations of glacial cycles. Only recently some existing models have been adapted to include slower processes, for example, peat carbon dynamics (Wania et al., 2009; Kleinen et al., 2012; Spahni et al., 2013; Stocker et al., 2014). However, the simulation of processes with long timescales, such as peat carbon accumulation or inert permafrost carbon dynamics, require necessarily a transient modelling approach, which is made feasible only by a fast model.

Here, we present a new land model primarily designed for paleoclimate applications, and therefore named PAleo LAnd DYNamics model (PALADYN), although also applicable to many other types of studies, including multi-ensemble future projections. The model has been designed to represent the land processes which are thought to be important both on short and very long timescales. The physical and biochemical processes are consistently coupled with each other. The model is intended to be used in the next generation of the CLIMBER EMIC and to substitute VECODE. CLIMBER employs a statistical dynamical atmosphere model. This type of model does not explicitly simulate weather, and therefore PALADYN is designed to simulate climatological mean seasonal cycle. Typical applications of such model are simulations of Earth system dynamics on astronomical and geological timescales. This is why particular attention is given to the selection of the proper complexity of the different processes which are represented in order to capture the main feedbacks in the system but at the same time maintain the model computationally efficient. We expect that PALADYN can also be used in other EMICs since most of them still employ rather simplistic LSMs.

\section{Model overview}

PALADYN is designed to operate on coarse resolution required for long-term simulations. Here, we test the model on a $5 \times 5^{\circ}$ horizontal resolution.

In each grid cell, the model distinguishes nine surface types (five vegetation types, bare soil, ice sheets, lakes and ocean shelf) (Fig. 1a). All surface type fractions can change over time. The fraction of vegetation types and bare soil is 
(a)

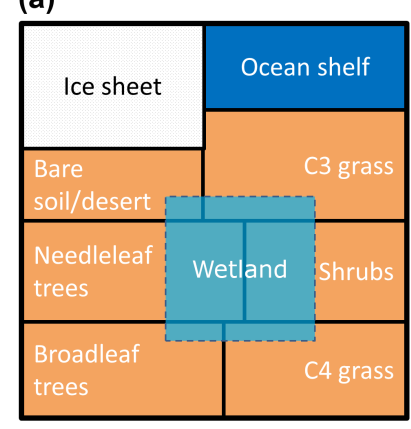

(b) (c)

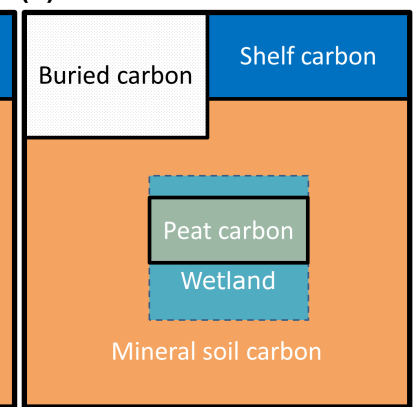

Figure 1. PALADYN surface types (a), soil columns (b) and soil carbon types (c).

computed by the dynamic vegetation module. The model is also able to handle changes in the fraction of ice sheet and ocean shelf, when given as input. This is necessary to simulate glacial cycles. So far, lakes are implemented in the model only as a placeholder.

Over each surface type, except ocean shelf, the model solves the surface energy balance and computes the fluxes of sensible, latent and ground heat and upward shortwave and longwave radiation.

Vegetation and bare soil share a single soil column (Fig. 1b) where temperature, moisture and carbon are discretized in five vertical layers reaching down to a depth of $3.9 \mathrm{~m}$. The top soil layer is $20 \mathrm{~cm}$ thick. A single snow layer with prognostic temperature and density is included in the model on top of the soil column. A 1-D heat diffusion equation is solved to compute snow and soil temperature with the ground heat flux as top boundary condition. Snowmelt and phase changes of water in the soil are explicitly considered. A surface hydrology module computes rainfall intercepted by vegetation, surface runoff and infiltration. Infiltration provides the top boundary condition for the solution of soil water equation based on Darcy's law. Given soil water content, the wetland fraction is computed following a simplified TOPMODEL approach (Niu et al., 2005).

For the ice sheet fraction, the temperature of the snow layer and of the top $3.9 \mathrm{~m}$ of ice below is computed in the same way as for the soil, but phase changes in the ice are inhibited. The temperature of the soil below the shelf water is needed to calculate the decomposition rate of shelf carbon. It is computed from a 1-D diffusion equation with the shelf water temperature prescribed as top boundary condition and assuming that the soil is saturated with liquid and/or frozen water. Phase changes are accounted for.

Photosynthesis is computed following Sitch et al. (2003) and Haxeltine and Prentice (1996a, b). Carbon assimilation by vegetation is coupled to the transpiration of water vapour through stomatal conductance. PALADYN includes a dynamic vegetation module based on TRIFFID (Cox, 2001) with five plant functional types competing for the grid cell share with their respective net primary production.
PALADYN includes a representation of soil carbon processes, including slow processes that are thought to be relevant over multimillennial timescales associated with glacialinterglacial transitions, when the appearance and disappearance of continental ice sheets, changes in sea level and land area can potentially strongly affect the land carbon cycle. PALADYN therefore includes processes with a long timescale, such as accumulation of carbon in peatlands, inert carbon locked in perennially frozen ground and carbon buried below ice sheets. It also accounts for changes in land area due to sea level variations and isostatic adjustment of the lithosphere to the ice sheet loading. During periods of low sea level, the model allows vegetation to grow on exposed ocean shelves. When sea level is rising, the exposed shelf becomes flooded and the vegetation dies.

The soil of the vegetated grid cell part, the soil below the ice sheet and soil below the shelf water have their own carbon pools (Fig. 1c) represented in general by a litter, a fast and a slow carbon pool in each soil layer. Carbon can be redistributed between the layers by vertical diffusion and advection. For the vegetated part, decomposition of organic matter is a function of soil temperature and soil moisture. Carbon in permanently frozen layers is assigned a long turnover time which effectively locks carbon in permafrost. Carbon buried below ice sheets and carbon on the flooded ocean shelf is treated separately, but is not discussed in detail in this paper.

A representation of peatland dynamics is also included in PALADYN. In inundated areas, peat is formed by accumulating carbon at the surface in the seasonally anoxically decomposing acrotelm. When the acrotelm carbon exceeds a critical value, carbon is transferred to the catotelm below the water table.

PALADYN also includes carbon isotopes ${ }^{13} \mathrm{C}$ and ${ }^{14} \mathrm{C}$, which are tracked trough all carbon pools. Isotopic discrimination is modelled only during photosynthesis.

A simple methane module is implemented to represent methane emissions from anaerobic carbon decomposition in wetlands (including peatlands) and flooded ocean shelf.

The processes represented in PALADYN are illustrated in Figs. 2 and 3. 


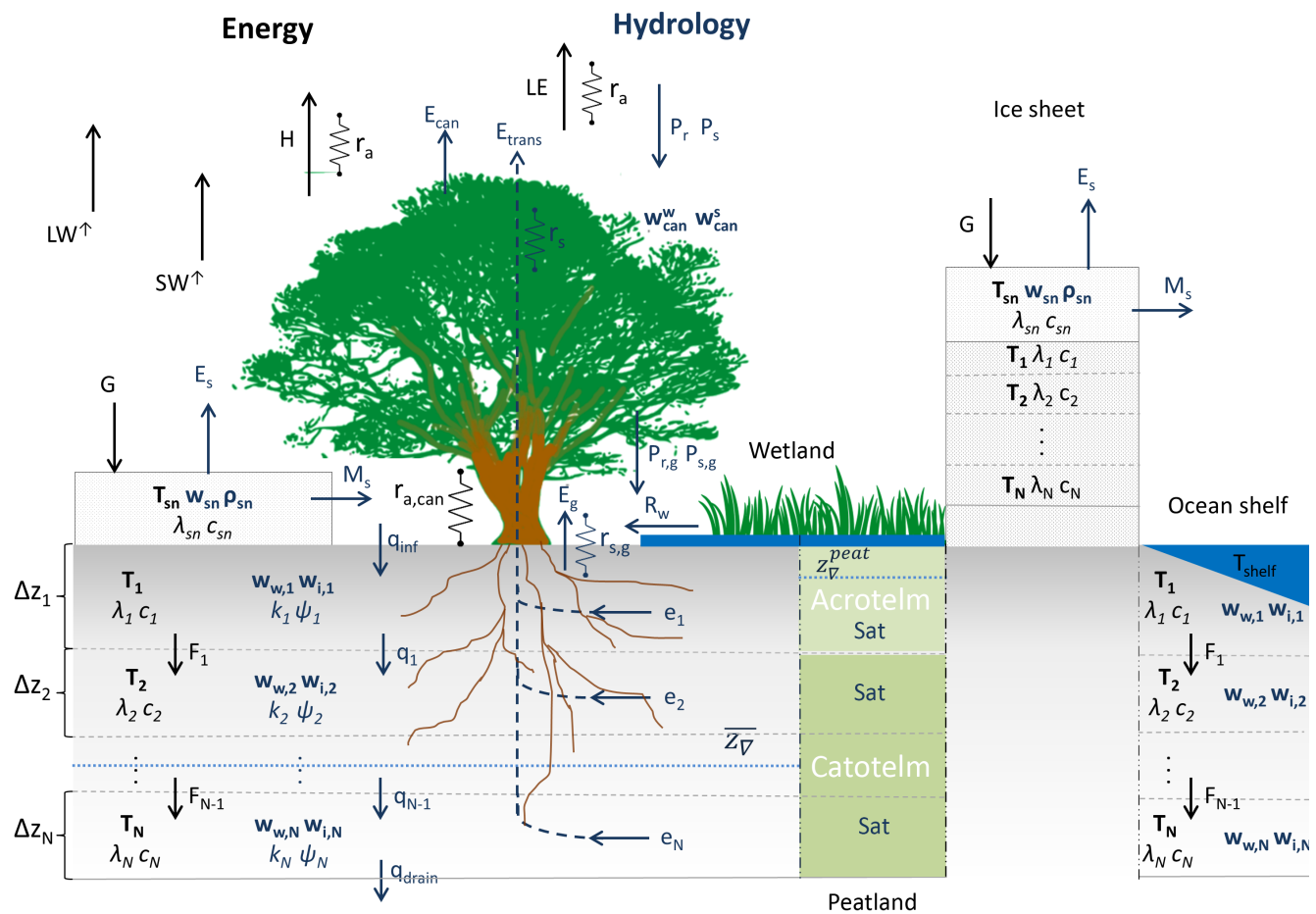

Figure 2. Illustration of the physical processes included in PALADYN. Energy fluxes and variables are indicated in black while water fluxes and hydrological variables are indicated in blue. Prognostic variables are in bold and fluxes are accompanied by arrows.

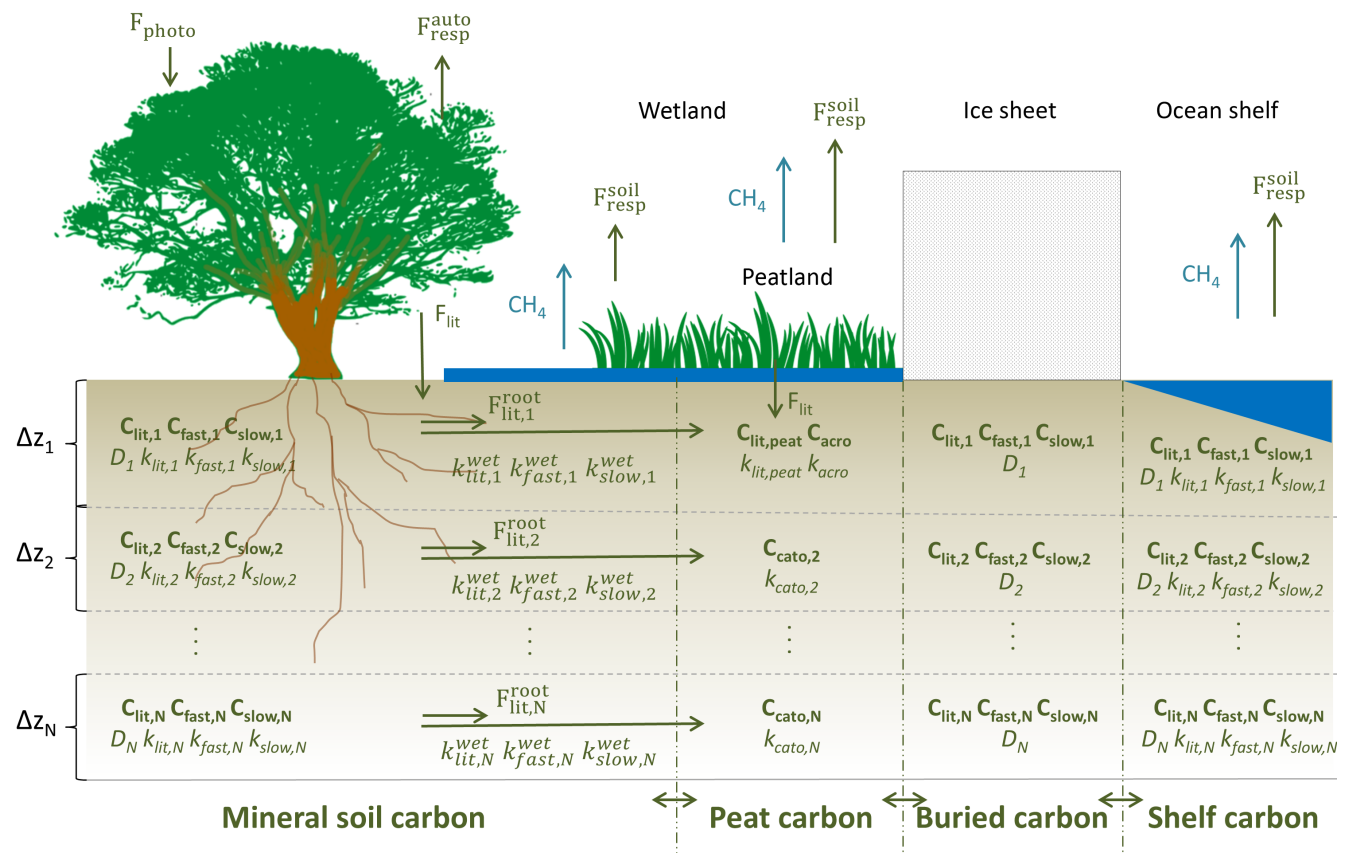

Figure 3. Illustration of the carbon cycle processes represented in PALADYN. Prognostic variables are in bold and fluxes are accompanied by arrows. 
All physical model components and photosynthesis are integrated with an implicit time-stepping scheme with a time step of 1 day. Dynamic vegetation and soil carbon processes are integrated with an implicit time-stepping scheme with a time step of 1 month.

The model is written in FORTRAN and uses the NCIO package (Robinson and Perrette, 2015) to handle input and output of data.

This paper describes the model representation of processes over ice free land. Processes related to changes in land-iceocean mask, buried and ocean shelf carbon will be described in a forthcoming paper.

\section{Surface energy balance and fluxes}

The surface energy balance equation at the land surface is written as

$(1-\alpha) \mathrm{SW}^{\downarrow}+\epsilon \mathrm{LW}^{\downarrow}-\mathrm{LW}^{\uparrow}-H-\mathrm{LE}-G=0$,

where $\alpha$ is surface albedo, $\mathrm{SW}^{\downarrow}$ is the incoming shortwave radiation, $\epsilon$ is the surface emissivity for longwave radiation, $\mathrm{LW}^{\downarrow}$ and $\mathrm{LW}^{\uparrow}$ are the incoming and outgoing longwave radiation at the surface, $H$ is the sensible heat flux, LE is the latent heat flux and $G$ the ground heat flux. Equation (1) is then solved for the skin temperature, $T_{*}$, using the formulations for the energy fluxes described next. All symbols are defined in Table 1.

The surface emitted longwave radiation is given by the Stefan-Boltzmann law with a surface-type-dependent emissivity $\epsilon$ (Sect. 3.2) to account for the fact that the surface is not a perfect black body:

$\mathrm{LW}^{\uparrow}=\epsilon \sigma T_{*}^{4}$.

$\sigma$ is the Stefan-Boltzmann constant. The sensible heat flux is computed from the temperature gradient between the surface and a reference height above the surface and an aerodynamic resistance, $r_{\mathrm{a}}$ (Sect. 3.3), using the bulk aerodynamic formula:

$H=\frac{\rho_{\mathrm{a}} C_{\mathrm{p}}}{r_{\mathrm{a}}}\left(T_{*}-T_{\mathrm{a}}\right)$,

where $\rho_{\mathrm{a}}$ is air density, $C_{\mathrm{p}}$ is the specific heat of air, $r_{\mathrm{a}}$ is the aerodynamic resistance and $T_{\mathrm{a}}$ is the temperature of the air at a reference level $z_{\text {ref. }}$.

Similarly, the latent heat flux over unvegetated surfaces is expressed in terms of the specific humidity gradient between the surface and a reference atmospheric level with the addition of a factor $\beta_{\mathrm{s}}$ (Sect. 3.4) representing a possible limitation in the moisture supply:

$\mathrm{LE}=L \frac{\rho_{\mathrm{a}}}{r_{\mathrm{a}}} \beta_{\mathrm{s}}\left(q_{\mathrm{sat}}\left(T_{*}\right)-q_{\mathrm{a}}\right)$.

$L$ is the latent heat of vaporization, $q_{\text {sat }}$ is the specific humidity at saturation and $q_{\mathrm{a}}$ is the specific humidity of air.
Table 1. Symbol definitions.

\begin{tabular}{|c|c|c|}
\hline Symbol & Units & Definition \\
\hline$\Delta$ & $\% o$ & isotopic discrimination \\
\hline$\Delta z_{l}$ & $\mathrm{~m}$ & thickness of soil layer $l$ \\
\hline$\Lambda$ & $\mathrm{kgCm}^{-2} \mathrm{~s}^{-1}$ & litterfall rate \\
\hline$\Lambda_{\text {bur }}$ & $\mathrm{kgCm}^{-2} \mathrm{~s}^{-1}$ & $\begin{array}{l}\text { vegetation carbon burial rate } \\
\text { under ice sheets }\end{array}$ \\
\hline$\Lambda_{1}$ & $\mathrm{kgCm}^{-2} \mathrm{~s}^{-1}$ & leaf litterfall rate \\
\hline$\Lambda_{\text {loc }}$ & $\mathrm{kgCm}^{-2} \mathrm{~s}^{-1}$ & local litterfall rate \\
\hline$\Lambda_{\text {peat }}$ & $\mathrm{kgCm}^{-2} \mathrm{~s}^{-1}$ & litterfall rate over peatland \\
\hline$\Lambda_{\text {shelf }}$ & $\mathrm{kgCm}^{-2} \mathrm{~s}^{-1}$ & litterfall rate over ocean shelf \\
\hline$\Lambda_{\text {veg }}$ & $\mathrm{kgCm}^{-2} \mathrm{~s}^{-1}$ & $\begin{array}{l}\text { litterfall rate over vegetated } \\
\text { grid cell area }\end{array}$ \\
\hline$\alpha$ & & surface albedo \\
\hline$\alpha_{\mathrm{a}}$ & & factor for APAR \\
\hline$\alpha^{\operatorname{dir}}$ & & albedo for direct radiation \\
\hline$\alpha^{\operatorname{dif}}$ & & albedo for diffuse radiation \\
\hline$\alpha^{\text {vis }}$ & & visible broadband albedo \\
\hline$\alpha^{\text {nir }}$ & & $\begin{array}{l}\text { near-infrared broadband } \\
\text { albedo }\end{array}$ \\
\hline$\alpha_{\text {can }}$ & & canopy albedo \\
\hline$\alpha_{\mathrm{g}}$ & & ground albedo \\
\hline$\alpha_{\text {int }}^{s}$ & & snowfall interception factor \\
\hline$\alpha_{\text {int }}^{w}$ & & rainfall interception factor \\
\hline$\alpha_{\text {leaf }}$ & & leaf albedo \\
\hline$\alpha_{\mathrm{sn}}$ & & snow albedo \\
\hline$\alpha_{\mathrm{sn}}^{\mathrm{can}}$ & & $\begin{array}{l}\text { albedo of snow-covered } \\
\text { canopy }\end{array}$ \\
\hline$\alpha_{\mathrm{sn}, \mathrm{fresh}}$ & & fresh snow albedo \\
\hline $\begin{array}{l}\alpha_{\text {snfree }} \\
\alpha_{\text {snfree }}^{\text {can }}\end{array}$ & & $\begin{array}{l}\text { snow-free surface albedo } \\
\text { albedo of snow-free canopy }\end{array}$ \\
\hline$\alpha_{\text {soil }}$ & & snow-free soil albedo \\
\hline$\beta_{\theta}$ & & $\begin{array}{l}\text { soil moisture limitation factor } \\
\text { for photosynthesis }\end{array}$ \\
\hline$\beta_{\mathrm{S}}$ & & surface evaporation factor \\
\hline$\gamma_{\nu}$ & $\mathrm{s}^{-1}$ & PFT disturbance rate \\
\hline$\gamma_{\nu, \min }$ & $\mathrm{s}^{-1}$ & $\begin{array}{l}\text { minimum PFT disturbance } \\
\text { rate }\end{array}$ \\
\hline$\gamma_{1}$ & $\mathrm{~s}^{-1}$ & leaf turnover rate \\
\hline$\gamma_{\mathrm{r}}$ & $\mathrm{s}^{-1}$ & root turnover rate \\
\hline$\gamma_{\mathrm{s}}$ & $\mathrm{s}^{-1}$ & stem turnover rate \\
\hline$\epsilon$ & & longwave emissivity \\
\hline$\eta$ & Pas & snow viscosity \\
\hline$\eta_{0}$ & Pas & reference snow viscosity \\
\hline$\theta$ & $\mathrm{m}^{3} \mathrm{~m}^{-3}$ & volumetric total soil moisture \\
\hline$\theta_{1}$ & $\mathrm{~m}^{3} \mathrm{~m}^{-3}$ & $\begin{array}{l}\text { top-layer volumetric soil } \\
\text { moisture }\end{array}$ \\
\hline$\theta_{\text {crit }}$ & $\mathrm{m}^{3} \mathrm{~m}^{-3}$ & critical soil moisture for fire \\
\hline$\theta_{\mathrm{fc}}$ & $\mathrm{m}^{3} \mathrm{~m}^{-3}$ & $\begin{array}{l}\text { volumetric soil moisture at } \\
\text { field capacity }\end{array}$ \\
\hline$\theta_{\mathrm{i}}$ & $\mathrm{m}^{3} \mathrm{~m}^{-3}$ & $\begin{array}{l}\text { volumetric frozen soil mois- } \\
\text { ture }\end{array}$ \\
\hline$\theta_{\mathrm{r}}$ & & $\begin{array}{l}\text { shape parameter for photosyn- } \\
\text { thesis }\end{array}$ \\
\hline$\theta_{\text {sat }}$ & $\mathrm{m}^{3} \mathrm{~m}^{-3}$ & soil porosity \\
\hline
\end{tabular}


Table 1. Continued.

\begin{tabular}{|c|c|c|}
\hline$\theta_{\mathrm{W}}$ & $\mathrm{m}^{3} \mathrm{~m}^{-3}$ & $\begin{array}{l}\text { volumetric liquid soil mois- } \\
\text { ture }\end{array}$ \\
\hline$\theta_{\mathrm{wp}}$ & $\mathrm{m}^{3} \mathrm{~m}^{-3}$ & $\begin{array}{l}\text { volumetric soil moisture at } \\
\text { wilting point }\end{array}$ \\
\hline$\kappa$ & & von Karman constant \\
\hline$\lambda$ & $\mathrm{W} \mathrm{m}^{-1} \mathrm{~K}^{-1}$ & heat conductivity \\
\hline$\lambda_{\mathrm{NPP}}$ & & NPP partitioning factor \\
\hline$\lambda_{\mathrm{a}}$ & $\mathrm{W} \mathrm{m}{ }^{-1} \mathrm{~K}^{-1}$ & heat conductivity of air \\
\hline$\lambda_{\mathrm{c}}$ & & $\begin{array}{l}\text { ratio of intercellular to atmo- } \\
\text { spheric } \mathrm{CO}_{2}\end{array}$ \\
\hline$\lambda_{\mathrm{dry}}$ & $\mathrm{W} \mathrm{m}^{-1} \mathrm{~K}^{-1}$ & heat conductivity of dry soil \\
\hline$\lambda_{\mathrm{i}}$ & $\mathrm{W} \mathrm{m} \mathrm{m}^{-1} \mathrm{~K}^{-1}$ & heat conductivity of ice \\
\hline$\lambda_{\mathrm{s}}$ & $\mathrm{W} \mathrm{m}^{-1} \mathrm{~K}^{-1}$ & heat conductivity of soil \\
\hline$\lambda_{\mathrm{s}, 1}$ & $\mathrm{~W} \mathrm{~m}^{-1} \mathrm{~K}^{-1}$ & $\begin{array}{l}\text { heat conductivity of top soil or } \\
\text { snow layer }\end{array}$ \\
\hline$\lambda_{\text {sat }}$ & $\mathrm{W} \mathrm{m}^{-1} \mathrm{~K}^{-1}$ & $\begin{array}{l}\text { heat conductivity of saturated } \\
\text { soil }\end{array}$ \\
\hline$\lambda_{\mathrm{sn}}$ & $\mathrm{W} \mathrm{m}^{-1} \mathrm{~K}^{-1}$ & heat conductivity of snow \\
\hline$\lambda_{\mathrm{W}}$ & $\mathrm{W} \mathrm{m}^{-1} \mathrm{~K}^{-1}$ & heat conductivity of water \\
\hline$\mu$ & radians & solar zenith angle \\
\hline$v$ & & PFT fractional area coverage \\
\hline$v_{\text {seed }}$ & & PFT seed fraction \\
\hline$\rho_{\mathrm{a}}$ & $\mathrm{kg} \mathrm{m}^{-3}$ & air density \\
\hline$\rho_{\text {acro }}$ & $\mathrm{kgCm}^{-3}$ & acrotelm carbon density \\
\hline$\rho_{\text {cato }}$ & $\mathrm{kgCm}^{-3}$ & catotelm carbon density \\
\hline$\rho_{\mathrm{i}}$ & $\mathrm{kg} \mathrm{m}^{-3}$ & density of ice \\
\hline$\rho_{\mathrm{sn}}$ & $\mathrm{kg} \mathrm{m}^{-3}$ & density of snow \\
\hline$\rho_{\text {sn }, \text { fresh }}$ & $\mathrm{kg} \mathrm{m}^{-3}$ & density of fresh snow \\
\hline$\rho_{\mathrm{sn}, \min }$ & $\mathrm{kg} \mathrm{m}^{-3}$ & minimum density of snow \\
\hline$\rho_{\mathrm{W}}$ & $\mathrm{kg} \mathrm{m}^{-3}$ & density of liquid water \\
\hline$\sigma$ & $\mathrm{W} \mathrm{m} \mathrm{m}^{-2} \mathrm{~K}^{-4}$ & Stefan-Boltzmann constant \\
\hline$\tau_{\text {fire }}$ & $\mathrm{s}$ & fire return timescale \\
\hline$\tau_{\mathrm{S}}$ & s & $\begin{array}{l}\text { canopy snow removal } \\
\text { timescale }\end{array}$ \\
\hline$\tau_{\mathrm{W}}$ & s & $\begin{array}{l}\text { canopy water removal } \\
\text { timescale }\end{array}$ \\
\hline$\phi$ & & phenology factor \\
\hline$\psi$ & $\mathrm{m}$ & soil matric potential \\
\hline$\psi_{\text {sat }}$ & $\mathrm{m}$ & saturated soil matric potential \\
\hline$A$ & $\mathrm{~ms}^{-1}$ & $\begin{array}{l}\text { vertical advection velocity for } \\
\text { soil carbon }\end{array}$ \\
\hline APAR & $\operatorname{molm}^{-2}$ day $^{-1}$ & $\begin{array}{l}\text { absorbed photosynthetically } \\
\text { active radiation }\end{array}$ \\
\hline$A_{\mathrm{g}}$ & $\mathrm{gCm}^{-2} \mathrm{day}^{-1}$ & daily gross assimilation \\
\hline$A_{\mathrm{n}}$ & $\mathrm{gCm}^{-2} \mathrm{day}^{-1}$ & daily net assimilation \\
\hline$A_{\text {nd }}$ & $\mathrm{gC} \mathrm{m}^{-2} \mathrm{day}^{-1}$ & daytime net assimilation \\
\hline$C_{\mathrm{DN}}^{\mathrm{m}}$ & & $\begin{array}{l}\text { neutral drag coefficient } \\
\text { for momentum }\end{array}$ \\
\hline$C_{\mathrm{DN}}^{\mathrm{h}}$ & & $\begin{array}{l}\text { neutral drag coefficient } \\
\text { for heat and water }\end{array}$ \\
\hline$C_{\mathrm{D}}^{\mathrm{m}}$ & & $\begin{array}{l}\text { drag coefficient for momen- } \\
\text { tum }\end{array}$ \\
\hline$C_{\mathrm{D}}^{\mathrm{h}}$ & & $\begin{array}{l}\text { drag coefficient for heat and } \\
\text { water }\end{array}$ \\
\hline$C_{\text {acro }}$ & $\mathrm{kgCm}^{-2}$ & acrotelm carbon \\
\hline
\end{tabular}

Table 1. Continued.

\begin{tabular}{|c|c|c|}
\hline$C_{\text {acro, crit }}$ & $\mathrm{kgCm}^{-2}$ & $\begin{array}{l}\text { critical acrotelm carbon for } \\
\text { catotelm formation }\end{array}$ \\
\hline$C_{\text {can }}$ & & below canopy drag coefficient \\
\hline$C_{\text {cato }}$ & $\mathrm{kgCm}^{-3}$ & catotelm carbon density \\
\hline$C_{\text {fast }}$ & $\mathrm{kgCm}^{-3}$ & fast soil carbon density \\
\hline$C_{\mathrm{i}}$ & $\mathrm{J} \mathrm{kg}^{-1} \mathrm{~K}^{-1}$ & specific heat capacity of ice \\
\hline$C_{\text {lit }}$ & $\mathrm{kgCm}^{-3}$ & litter carbon density \\
\hline$C_{\text {lit,peat }}$ & $\mathrm{kgCm}^{-2}$ & peat litter carbon \\
\hline$C_{\mathrm{p}}$ & $\mathrm{Jkg}^{-1} \mathrm{~K}^{-1}$ & $\begin{array}{l}\text { specific heat capacity of air at } \\
\text { constant pressure }\end{array}$ \\
\hline$C_{\text {peat }}$ & $\mathrm{kgCm}^{-2}$ & peat carbon \\
\hline$C_{\text {peat }}^{\text {crit }}$ & $\mathrm{kgCm}^{-2}$ & $\begin{array}{l}\text { minimum peat carbon content } \\
\text { for peat survival }\end{array}$ \\
\hline$C_{\text {slow }}$ & $\mathrm{kgCm}^{-3}$ & slow soil carbon density \\
\hline$C_{\mathrm{v}}$ & $\mathrm{kgCm}^{-2}$ & vegetation carbon \\
\hline$C_{\mathrm{v}, \mathrm{ag}}$ & $\mathrm{kgCm}^{-2}$ & $\begin{array}{l}\text { aboveground vegetation car- } \\
\text { bon }\end{array}$ \\
\hline$C_{\mathrm{v}, \text { high }}$ & $\mathrm{kgCm}^{-2}$ & $\begin{array}{l}\text { aboveground vegetation car- } \\
\text { bon parameter for fire }\end{array}$ \\
\hline$C_{\mathrm{v}, 1}$ & $\mathrm{kgCm}^{-2}$ & leaf carbon \\
\hline$C_{\mathrm{v}, \text { low }}$ & $\mathrm{kgCm}^{-2}$ & $\begin{array}{l}\text { aboveground vegetation car- } \\
\text { bon parameter for fire }\end{array}$ \\
\hline$C_{\mathrm{V}, \mathrm{r}}$ & $\mathrm{kgCm}^{-2}$ & root carbon \\
\hline$C_{\mathrm{v}, \mathrm{s}}$ & $\mathrm{kgCm}^{-2}$ & stem carbon \\
\hline$C_{\mathrm{W}}$ & $\mathrm{J} \mathrm{kg}^{-1} \mathrm{~K}^{-1}$ & specific heat capacity of water \\
\hline$D$ & $\mathrm{~m}^{2} \mathrm{~s}^{-1}$ & vertical soil carbon diffusivity \\
\hline$D_{\text {bio }}$ & $\mathrm{m}^{2} \mathrm{~s}^{-1}$ & $\begin{array}{l}\text { bioturbation carbon diffusiv- } \\
\text { ity }\end{array}$ \\
\hline$D_{\text {cryo }}$ & $\mathrm{m}^{2} \mathrm{~s}^{-1}$ & $\begin{array}{l}\text { cryoturbation carbon diffusiv- } \\
\text { ity }\end{array}$ \\
\hline E & $\mathrm{kg} \mathrm{m}^{-2} \mathrm{~s}^{-1}$ & evapotranspiration \\
\hline$E_{\text {can }}$ & $\mathrm{kg} \mathrm{m}^{-2} \mathrm{~s}^{-1}$ & $\begin{array}{l}\text { canopy evaporation and subli- } \\
\text { mation }\end{array}$ \\
\hline$E_{\text {can }}^{\mathrm{s}}$ & $\mathrm{kg} \mathrm{m}^{-2} \mathrm{~s}^{-1}$ & canopy sublimation \\
\hline$E_{\mathrm{can}}^{\mathrm{W}}$ & $\mathrm{kg} \mathrm{m}^{-2} \mathrm{~s}^{-1}$ & canopy evaporation \\
\hline$E_{\mathrm{S}}$ & $\mathrm{kg} \mathrm{m}^{-2} \mathrm{~s}^{-1}$ & snow sublimation \\
\hline$G$ & $\mathrm{~W} \mathrm{~m}^{-2}$ & ground heat flux \\
\hline$H$ & $\mathrm{~W} \mathrm{~m}^{-2}$ & sensible heat flux \\
\hline$I_{\mathrm{can}}^{\mathrm{s}}$ & $\mathrm{kg} \mathrm{m}^{-2} \mathrm{~s}^{-1}$ & canopy snow interception \\
\hline$I_{\text {can }}^{\mathrm{W}}$ & $\mathrm{kg} \mathrm{m}^{-2} \mathrm{~s}^{-1}$ & canopy rain interception \\
\hline$J_{\mathrm{C}}$ & $\mathrm{gCm}^{-2}$ day $^{-1}$ & $\begin{array}{l}\text { RuBisCO-limited photosyn- } \\
\text { thesis rate }\end{array}$ \\
\hline$J_{\mathrm{E}}$ & $\mathrm{gCm}^{-2} \mathrm{day}^{-1}$ & $\begin{array}{l}\text { light-limited photosynthesis } \\
\text { rate }\end{array}$ \\
\hline$K$ & & Kersten number \\
\hline$L$ & $\mathrm{~J} \mathrm{~kg}^{-1}$ & latent heat of vaporization \\
\hline$L_{\mathrm{ai}}$ & $\mathrm{m}^{2} \mathrm{~m}^{-2}$ & leaf area index \\
\hline$L_{\mathrm{ai}, \mathrm{b}}$ & $\mathrm{m}^{2} \mathrm{~m}^{-2}$ & balanced leaf area index \\
\hline$L_{\mathrm{f}}$ & $\mathrm{J} \mathrm{kg}^{-1}$ & latent heat of fusion of water \\
\hline $\mathrm{LW}^{\downarrow}$ & $\mathrm{W} \mathrm{m}^{-2}$ & $\begin{array}{l}\text { downward longwave radiation } \\
\text { at the surface }\end{array}$ \\
\hline $\mathrm{LW}^{\uparrow}$ & $\mathrm{W} \mathrm{m}^{-2}$ & $\begin{array}{l}\text { upward longwave radiation at } \\
\text { the surface }\end{array}$ \\
\hline$M_{\mathrm{S}}$ & $\mathrm{kg} \mathrm{m}^{-2} \mathrm{~s}^{-1}$ & snowmelt \\
\hline NPP & $\mathrm{kgCm}^{-2} \mathrm{~s}^{-1}$ & net primary production \\
\hline
\end{tabular}


Table 1. Continued.

\begin{tabular}{|c|c|c|c|c|c|}
\hline$P_{\mathrm{S}}$ & $\mathrm{kg} \mathrm{m}^{-2} \mathrm{~s}^{-1}$ & snowfall rate & $d_{\mathrm{h}}$ & hours & day length \\
\hline$P_{\mathrm{S}, \mathrm{g}}$ & $\mathrm{kg} \mathrm{m}^{-2} \mathrm{~s}^{-1}$ & $\begin{array}{l}\text { snowfall rate reaching the } \\
\text { ground }\end{array}$ & $\begin{array}{l}d_{\mathrm{r}, 1} \\
d_{\mathrm{r}, 2}\end{array}$ & $\begin{array}{l}\mathrm{m} \\
\mathrm{m}\end{array}$ & $\begin{array}{l}\text { root distribution parameter } \\
\text { root distribution parameter }\end{array}$ \\
\hline$P_{\mathrm{r}}$ & $\mathrm{kg} \mathrm{m}^{-2} \mathrm{~s}^{-1}$ & rainfall rate & $e^{1,2}$ & $\mathrm{~kg} \mathrm{~m}^{-2} \mathrm{~s}^{-1}$ & soil moisture removal by \\
\hline$P_{\mathrm{r}, \mathrm{g}}$ & $\mathrm{kg} \mathrm{m}^{-2} \mathrm{~s}^{-1}$ & $\begin{array}{l}\text { rainfall rate reaching the } \\
\text { ground }\end{array}$ & $f_{\nabla}$ & & $\begin{array}{l}\text { evapotranspiration } \\
\text { parameter for computation of }\end{array}$ \\
\hline$R_{\mathrm{d}}$ & $\mathrm{gCm}^{-2}$ day $^{-1}$ & leaf respiration & & & water table depth \\
\hline$R_{\mathrm{i}}$ & & bulk Richardson number & $f_{\theta}$ & & soil moisture factor for soil \\
\hline$R_{\mathrm{W}}$ & $\mathrm{kg} \mathrm{m}^{-2} \mathrm{~s}^{-1}$ & surface water runoff & & & carbon decomposition rate \\
\hline SLA & $\mathrm{m}^{2} \mathrm{kgC}^{-1}$ & specific leaf area & $f_{\theta}$,peat & & soil moisture factor for peat \\
\hline$S_{\mathrm{ai}}$ & $\mathrm{m}^{2} \mathrm{~m}^{-2}$ & stem area index & & & carbon decomposition rate \\
\hline $\mathrm{SW}^{\downarrow}$ & $\mathrm{W} \mathrm{m}^{-2}$ & $\begin{array}{l}\text { downward shortwave radia- } \\
\text { tion at the surface }\end{array}$ & $f_{\theta}$, sat & & $\begin{array}{l}\text { so1l moisture factor for so1l } \\
\text { carbon decomposition rate at } \\
\text { saturation }\end{array}$ \\
\hline$T_{0}$ & $\mathrm{~K}$ & freezing temperature of water & $f_{\mathrm{T}}$ & & temperature factor for soil car- \\
\hline$T_{*}$ & $\mathrm{~K}$ & skin temperature & 11 & & bon decomposition rate \\
\hline $\begin{array}{l}T_{\mathrm{a}} \\
T_{\mathrm{cmon}}^{\max }\end{array}$ & $\begin{array}{l}\mathrm{K} \\
\mathrm{K}\end{array}$ & $\begin{array}{l}\text { air temperature at height } z_{\text {ref }} \\
\text { maximum coldest month tem- }\end{array}$ & $f_{\mu}$ & & $\begin{array}{l}\text { solar zenith angle factor for } \\
\text { snow albedo }\end{array}$ \\
\hline$T_{\mathrm{cmon}}^{\min }$ & $\mathrm{K}$ & $\begin{array}{l}\text { minimum coldest month tem- } \\
\text { perature for establishment }\end{array}$ & $\begin{array}{l}f_{\text {age }} \\
f_{\text {can }}^{\mathrm{s}} \\
f^{\mathrm{W}}\end{array}$ & & $\begin{array}{l}\text { snow age factor } \\
\text { snow-covered canopy fraction }\end{array}$ \\
\hline$T_{\mathrm{cmon}}^{\mathrm{phen}}$ & $\mathrm{K}$ & coldest month temperature for & $J_{\text {can }}$ & & $\begin{array}{l}\text { water-covered canopy rrac- } \\
\text { tion }\end{array}$ \\
\hline$T_{\text {gdd }}^{\text {base }}$ & $\mathrm{K}$ & $\begin{array}{l}\text { phenology } \\
\text { base temperature for phenol- }\end{array}$ & $f_{\text {frz }, \text { crit }}$ & & $\begin{array}{l}\text { critical fraction of frozen soil } \\
\text { water for permafrost carbon }\end{array}$ \\
\hline$T_{\mathrm{s}, 1}$ & $\mathrm{~K}$ & $\begin{array}{l}\text { ogy } \\
\text { top soil layer or snow temper- }\end{array}$ & $f_{\text {ice }}$ & & $\begin{array}{l}\text { fraction of grid cell covered } \\
\text { by ice sheets }\end{array}$ \\
\hline$T_{\mathrm{S}}$ & K & $\begin{array}{l}\text { ature } \\
\text { soil-snow temperature }\end{array}$ & $f_{\text {inert }}$ & & $\begin{array}{l}\text { frozen soil factor for soil car- } \\
\text { bon decomposition }\end{array}$ \\
\hline$T_{\mathrm{sn}}$ & $\mathrm{K}$ & snow temperature & $f_{\text {inun }}$ & & inundated grid cell fraction \\
\hline VPD & $\mathrm{kPa}$ & vapour pressure deficit & $f_{\text {lit }}^{\text {resp }}$ & & fraction of decomposed litter \\
\hline$V_{\mathrm{a}}$ & $\mathrm{ms}^{-1}$ & wind speed at height $z_{\text {ref }}$ & & & carbon going to atmosphere \\
\hline$V_{\mathrm{m}}$ & $\mathrm{gC} \mathrm{m}^{-2} \mathrm{day}^{-1}$ & $\begin{array}{l}\text { maximum daily rate of net } \\
\text { photosynthesis }\end{array}$ & $f_{\text {lit } \rightarrow \text { fast }}$ & & $\begin{array}{l}\text { fraction of decomposed litter } \\
\text { transferred to fast carbon pool }\end{array}$ \\
\hline$a_{\mathrm{C}}$ & & factor for leaf respiration & $f_{\text {lit } \rightarrow \text { slow }}$ & & fraction of decomposed lit- \\
\hline$a_{\mathrm{wh}}$ & $\mathrm{m}$ & $\begin{array}{l}\text { allometric coefficient for plant } \\
\text { height }\end{array}$ & & & $\begin{array}{l}\text { ter transferred to slow carbon } \\
\text { pool }\end{array}$ \\
\hline$a_{\mathrm{wl}}$ & $\mathrm{kgCm}^{-2}$ & allometric coefficient & $f_{\text {oxic }}$ & & fraction of litter and acrotelm \\
\hline$b$ & & $\begin{array}{l}\text { Clapp and Hornberger param- } \\
\text { eter }\end{array}$ & $f_{\text {peat }}$ & & $\begin{array}{l}\text { respiring in oxic conditions } \\
\text { peatland fraction }\end{array}$ \\
\hline$b_{\mathrm{wl}}$ & & allometric coefficient & $f_{\text {peat }}^{\min }$ & & minimum peatland fraction \\
\hline$c$ & $\mathrm{Jm}^{-3} \mathrm{~K}^{-1}$ & volumetric heat capacity & $f_{\text {peat, pot }}$ & & potential peatland fraction \\
\hline$c_{1}$ & $\mathrm{~g} \mathrm{~mol}^{-1}$ & $\begin{array}{l}\text { factor for light-limited assim- } \\
\text { ilation }\end{array}$ & $\begin{array}{l}f_{\text {sat }} \\
f_{\text {sat }}^{\max }\end{array}$ & & $\begin{array}{l}\text { saturated grid cell fraction } \\
\text { maximum saturated grid cell }\end{array}$ \\
\hline$c_{2}$ & & factor for RuBisCO-limited & & & fraction \\
\hline & & assimilation & $f_{\text {shelf }}$ & & fraction of grid cell below sea \\
\hline$c_{\mathrm{a}}$ & $\mathrm{mol} \mathrm{mol}^{-1}$ & $\begin{array}{l}\text { atmospheric } \mathrm{CO}_{2} \text { mole frac- } \\
\text { tion }\end{array}$ & $f_{\mathrm{sn}}$ & & $\begin{array}{l}\text { level } \\
\text { snow fraction }\end{array}$ \\
\hline$c_{\mathrm{i}}$ & $\mathrm{mol} \mathrm{mol}^{-1}$ & $\begin{array}{l}\text { intercellular } \mathrm{CO}_{2} \text { mole frac- } \\
\text { tion }\end{array}$ & $\begin{array}{l}f_{\mathrm{sv}} \\
f_{\mathrm{sv}}^{\mathrm{dir}}\end{array}$ & & $\begin{array}{l}\text { sky view factor } \\
\text { direct beam sky view factor }\end{array}$ \\
\hline $\begin{array}{l}c_{i j} \\
c_{\mathrm{q}}\end{array}$ & $\mathrm{molJ}^{-1}$ & $\begin{array}{l}\text { PFT competition coefficients } \\
\text { conversion factor for solar ra- }\end{array}$ & $f_{\mathrm{sv}}^{\mathrm{dif}}$ & & $\begin{array}{l}\text { diffuse radiation sky view fac- } \\
\text { tor }\end{array}$ \\
\hline & & diation & $f_{\text {veg } \rightarrow \text { bur }}$ & & fraction of vegetation carbon \\
\hline$c_{\mathrm{S}}$ & $\mathrm{Jm}^{-3} \mathrm{~K}^{-1}$ & $\begin{array}{l}\text { volumetric heat capacity of } \\
\text { dry soil }\end{array}$ & $f_{\text {wet }}$ & & $\begin{array}{l}\text { buried below ice sheets } \\
\text { wetland fraction }\end{array}$ \\
\hline$c_{\mathrm{sn}}$ & $\mathrm{Jm}^{-3} \mathrm{~K}^{-1}$ & $\begin{array}{l}\text { volumetric heat capacity of } \\
\text { snow }\end{array}$ & $\begin{array}{l}g \\
\text { gdd }\end{array}$ & $\begin{array}{l}\mathrm{ms}^{-2} \\
\mathrm{~K}\end{array}$ & $\begin{array}{l}\text { gravitational acceleration } \\
\text { growing degree days above }\end{array}$ \\
\hline$d$ & $\mathrm{~m}$ & zero plane displacement & & & $T_{\text {gdd }}^{\text {base }}$ \\
\hline
\end{tabular}

Table 1. Continued. 
Table 1. Continued.

\begin{tabular}{|c|c|c|}
\hline $\operatorname{gdd}_{\text {crit }}$ & $\mathrm{K}$ & $\begin{array}{l}\text { critical growing degree days } \\
\text { for phenology }\end{array}$ \\
\hline $\operatorname{gdd}_{\min }$ & $\mathrm{K}$ & $\begin{array}{l}\text { minimum growing degree } \\
\text { days for establishment }\end{array}$ \\
\hline$g_{0}$ & $\mathrm{~ms}^{-1}$ & cuticular canopy conductance \\
\hline$g_{1}$ & & $\begin{array}{l}\text { parameter in optimal stomatal } \\
\text { conductance model }\end{array}$ \\
\hline$g_{\text {can }}$ & $\mathrm{ms}^{-1}$ & canopy conductance \\
\hline$g_{\min }$ & $\mathrm{ms}^{-1}$ & $\begin{array}{l}\text { minimum canopy conduc- } \\
\text { tance }\end{array}$ \\
\hline$h_{\mathrm{sn}}$ & $\mathrm{m}$ & snow thickness \\
\hline$h_{\text {soil }}$ & $\mathrm{m}$ & depth of the soil column \\
\hline$h_{\mathrm{V}}$ & $\mathrm{m}$ & vegetation height \\
\hline$k$ & $\mathrm{~kg} \mathrm{~m}^{-2} \mathrm{~s}^{-1}$ & hydraulic soil conductivity \\
\hline$k_{\text {acro }}$ & $s^{-1}$ & acrotelm carbon turnover rate \\
\hline$k_{\text {acro } \rightarrow \text { cato }}$ & $s^{-1}$ & catotelm formation rate \\
\hline$k_{\text {cato }}$ & $s^{-1}$ & catotelm carbon turnover rate \\
\hline$k_{\text {ext }}$ & & $\begin{array}{l}\text { extinction coefficient for radi- } \\
\text { ation }\end{array}$ \\
\hline$k_{\text {fast }}$ & $\mathrm{s}^{-1}$ & fast carbon turnover rate \\
\hline$k_{\text {fast }, 10}$ & $\mathrm{~s}^{-1}$ & $\begin{array}{l}\text { fast soil carbon turnover rate } \\
\text { at } 10^{\circ} \mathrm{C}\end{array}$ \\
\hline$k_{\text {inert }}$ & $\mathrm{s}^{-1}$ & inert soil carbon turnover rate \\
\hline$k_{\text {lit }}$ & $s^{-1}$ & litter carbon turnover rate \\
\hline$k_{\text {lit }, 10}$ & $\mathrm{~s}^{-1}$ & $\begin{array}{l}\text { litter carbon turnover rate at } \\
10^{\circ} \mathrm{C}\end{array}$ \\
\hline$k_{\text {lit,peat }}$ & $s^{-1}$ & peat litter carbon turnover rate \\
\hline$k_{\text {sat }}$ & $\mathrm{kg} \mathrm{m}^{-2} \mathrm{~s}^{-1}$ & $\begin{array}{l}\text { hydraulic soil conductivity at } \\
\text { saturation }\end{array}$ \\
\hline$k_{\text {slow }}$ & $s^{-1}$ & slow soil carbon turnover rate \\
\hline$k_{\text {slow, } 10}$ & $\mathrm{~s}^{-1}$ & $\begin{array}{l}\text { slow soil carbon turnover rate } \\
\text { at } 10^{\circ} \mathrm{C}\end{array}$ \\
\hline$k_{\rho}$ & $\mathrm{m}^{3} \mathrm{~kg}^{-1}$ & $\begin{array}{l}\text { factor for density dependence } \\
\text { of snow viscosity }\end{array}$ \\
\hline$k_{\mathrm{T}}$ & $\mathrm{K}^{-1}$ & $\begin{array}{l}\text { factor for temperature depen- } \\
\text { dence of snow viscosity }\end{array}$ \\
\hline$n_{\mathrm{al}}$ & & $\begin{array}{l}\text { multiple of active layer thick- } \\
\text { ness for cryoturbation }\end{array}$ \\
\hline$p_{\mathrm{a}}$ & $\mathrm{Pa}$ & $\begin{array}{l}\text { partial pressure of atmo- } \\
\text { spheric } \mathrm{CO}_{2}\end{array}$ \\
\hline$p_{\mathrm{i}}$ & $\mathrm{Pa}$ & $\begin{array}{l}\text { partial pressure of intercellu- } \\
\text { lar } \mathrm{CO}_{2}\end{array}$ \\
\hline$q$ & $\mathrm{~kg} \mathrm{~m}^{-2} \mathrm{~s}^{-1}$ & soil water flux \\
\hline$q_{\mathrm{a}}$ & $\mathrm{kg} \mathrm{kg}^{-1}$ & air-specific humidity at height \\
\hline$q_{\text {drain }}$ & $\mathrm{kg} \mathrm{m}^{-2} \mathrm{~s}^{-1}$ & $\begin{array}{l}z_{\text {ref }} \\
\text { soil water drainage }\end{array}$ \\
\hline$q_{\text {inf }}$ & $\mathrm{kg} \mathrm{m}^{-2} \mathrm{~s}^{-1}$ & soil water infiltration \\
\hline$q_{\text {inf }}^{\max }$ & $\mathrm{kg} \mathrm{m}^{-2} \mathrm{~s}^{-1}$ & $\begin{array}{l}\text { maximum soil water infiltra- } \\
\text { tion }\end{array}$ \\
\hline $\begin{array}{l}q_{\text {sat }} \\
r\end{array}$ & $\mathrm{~kg} \mathrm{~kg}^{-1}$ & $\begin{array}{l}\text { specific humidity at saturation } \\
\text { cumulative root fraction }\end{array}$ \\
\hline$r_{\mathrm{a}}$ & $\mathrm{sm}^{-1}$ & aerodynamic resistance \\
\hline$r_{\mathrm{a}, \mathrm{can}}$ & $\mathrm{sm}^{-1}$ & $\begin{array}{l}\text { below-canopy aerodynamic } \\
\text { resistance }\end{array}$ \\
\hline$r_{1}$ & & root fraction in layer $l$ \\
\hline
\end{tabular}

Table 1. Continued.

\begin{tabular}{|c|c|c|}
\hline$r_{\mathrm{s}}$ & $\mathrm{sm}^{-1}$ & $\begin{array}{l}\text { canopy resistance to water } \\
\text { vapour flux }\end{array}$ \\
\hline$w_{\text {can }}^{\mathrm{W}}$ & $\mathrm{kg} \mathrm{m}^{-2}$ & canopy liquid water \\
\hline$w_{\text {can }}^{\mathrm{s}}$ & $\mathrm{kg} \mathrm{m}^{-2}$ & canopy snow water equivalent \\
\hline$w_{\mathrm{i}}$ & $\mathrm{kg} \mathrm{m}^{-2}$ & soil frozen water content \\
\hline$w_{\mathrm{sn}}$ & $\mathrm{kg} \mathrm{m}^{-2}$ & snow water equivalent \\
\hline$w_{\mathrm{W}}$ & $\mathrm{kg} \mathrm{m}^{-2}$ & soil liquid water content \\
\hline$w_{\mathrm{w}}^{\max }$ & $\mathrm{kg} \mathrm{m}^{-2}$ & $\begin{array}{l}\text { maximum soil liquid water } \\
\text { content }\end{array}$ \\
\hline$z_{0}^{\mathrm{b}}$ & $\mathrm{m}$ & bare soil roughness length \\
\hline$z_{0}^{\mathrm{i}}$ & $\mathrm{m}$ & ice roughness length \\
\hline$z_{0}^{\mathrm{sn}}$ & $\mathrm{m}$ & snow roughness length \\
\hline$z_{0}^{\text {snfree }}$ & $\mathrm{m}$ & snow-free roughness length \\
\hline$z_{0}^{\mathrm{V}}$ & $\mathrm{m}$ & vegetation roughness length \\
\hline$z \nabla$ & $\mathrm{m}$ & $\begin{array}{l}\text { grid cell mean water table } \\
\text { depth }\end{array}$ \\
\hline$z_{\nabla}^{\min }$ & $\mathrm{m}$ & minimum water table depth \\
\hline$z_{\nabla}^{\text {peat }}$ & $\mathrm{m}$ & peatland water table depth \\
\hline$z_{\text {acro }}$ & $\mathrm{m}$ & acrotelm thickness \\
\hline$z_{\mathrm{al}}$ & $\mathrm{m}$ & active layer thickness \\
\hline$z_{\mathrm{h}}$ & $\mathrm{m}$ & roughness length for scalars \\
\hline$z_{\mathrm{m}}$ & $\mathrm{m}$ & $\begin{array}{l}\text { roughness length for momen- } \\
\text { tum }\end{array}$ \\
\hline$z_{\text {ref }}$ & $\mathrm{m}$ & reference height \\
\hline
\end{tabular}

Over vegetation, the latent heat flux consists of contributions from transpiration of water vapour through leaf stomata during photosynthesis, soil-snow evaporation and sublimation from below the canopy and evaporation and sublimation of precipitation intercepted by the canopy:

$$
\begin{aligned}
\mathrm{LE} & =L \frac{\rho_{\mathrm{a}}}{r_{\mathrm{a}}+r_{\mathrm{s}}}\left(q_{\mathrm{sat}}\left(T_{*}\right)-q_{\mathrm{a}}\right) \\
& +L \frac{\rho_{\mathrm{a}}}{r_{\mathrm{a}}+r_{\mathrm{a}, \mathrm{can}}} \beta_{\mathrm{s}}\left(q_{\mathrm{sat}}\left(T_{\mathrm{s}, 1}\right)-q_{\mathrm{a}}\right)+L \cdot E_{\mathrm{can}} .
\end{aligned}
$$

$r_{\mathrm{a}, \mathrm{can}}$ is the aerodynamic resistance between the soil surface and the vegetation canopy (Sect. 3.3) and $r_{\mathrm{s}}$ is the canopy resistance to water vapour flux through the leaf stomata as described in detail in Sect. 3.4). $T_{\mathrm{s}, 1}$ is the temperature of the top soil layer, or the snow layer temperature if snow is present. Canopy evaporation and sublimation, $E_{\mathrm{can}}$, is computed using the skin temperature from the previous time step as described in Sect. 5.1.

The ground heat flux is represented by conduction of heat between the skin and the centre of the snow layer or top soil layer:

$G=2 \lambda_{\mathrm{s}, 1} \frac{T_{*}-T_{\mathrm{s}, 1}}{\Delta z_{1}}$.

$\lambda_{\mathrm{s}, 1}$ is the heat conductivity and $\Delta z_{1}$ is the thickness of the snow layer or top soil layer.

The prognostic terms in $T_{*}$ in the formulation of the surface energy fluxes are then linearized using Taylor series ex- 
pansion assuming that the temperature at the new time step $T_{*, n+1}=T_{*, n}+\Delta T_{*}$ with $\Delta T_{*} \ll T_{*}$ :

$T_{*, n+1}^{4}=T_{*, n}^{4}+4 T_{*, n}^{3}\left(T_{*, n+1}-T_{*, n}\right)$,

$q_{\mathrm{sat}}\left(T_{*, n+1}\right)=q_{\mathrm{sat}}\left(T_{*}\right)+\left.\frac{d q_{\mathrm{sat}}}{d T_{*}}\right|_{T_{*}=T_{*, n}}\left(T_{*, n+1}-T_{*, n}\right)$.

Equation (1) can then be solved explicitly for the skin temperature at the new time step, $T_{*, n+1}$, separately for each surface type.

If snow is present and the skin temperature is above freezing, the surface energy fluxes are diagnosed first with the skin temperature greater then $0{ }^{\circ} \mathrm{C}$ and then with skin temperature set to $0^{\circ} \mathrm{C}$. The difference between the sum of the energy fluxes is then added to the energy available to melt the snow layer.

Given the new skin temperatures, the ground heat flux $G$ and its derivative with respect to top soil or snow temperature $\left(\partial G / \partial T_{\mathrm{s}, 1}\right)$ are diagnosed and used as input for the soil heat diffusion equation. After the top soil-snow temperature has been updated as described in Sect. 4 , it is used to compute the total ground heat flux $G_{\text {new }}=G+\partial G / \partial T_{\mathrm{s}, 1} \Delta T_{\mathrm{s}, 1}$. Skin temperature is then updated using $G_{\text {new }}$ and all remaining surface energy and water fluxes are diagnosed.

In the next sections, the surface parameters needed for the solution of the surface energy balance equation are described.

\subsection{Surface albedo}

PALADYN distinguishes between direct beam and diffuse albedo in the visible and infrared spectral bands. For ice sheets and bare soil the surface albedo is computed as a weighted mean of snow-free $\left(\alpha_{\text {snfree }}\right)$ and snow $\left(\alpha_{\text {sn }}\right)$ albedos:

$\alpha=f_{\mathrm{sn}} \alpha_{\mathrm{sn}}+\left(1-f_{\mathrm{sn}}\right) \alpha_{\mathrm{snfree}}$, bare soil, ice sheets.

The snow-free soil albedo in the visible and near-infrared band is prescribed from Dazlich and Los (2009). The fraction considered to be snow covered depends on snow height $\left(h_{\mathrm{sn}}\right)$ and snow-free roughness length $\left(z_{0}^{\text {snfree }}\right)$ of the surface (Sect. 3.3) following Oleson et al. (2004):

$f_{\mathrm{sn}}=\frac{h_{\mathrm{sn}}}{h_{\mathrm{sn}}+10 z_{0}^{\text {snfree }}}$.

The albedo of grass and shrubs is computed by additionally separating the snow-free albedo into bare soil and canopy albedo through a sky view factor $f_{\mathrm{sv}}$ :

$$
\begin{aligned}
\alpha & =f_{\mathrm{sn}} \alpha_{\mathrm{sn}}+\left(1-f_{\mathrm{sn}}\right)\left(1-f_{\mathrm{sv}}\right) \alpha_{\mathrm{snfree}}^{\mathrm{can}} \\
& +\left(1-f_{\mathrm{sn}}\right) f_{\mathrm{sv}} \alpha_{\text {soil }}, \text { grass, shrubs. }
\end{aligned}
$$

The sky view factor is a function of the leaf area index $\left(L_{\mathrm{ai}}\right)$, the stem area index $\left(S_{\mathrm{ai}}\right)$ and an extinction coefficient $k_{\mathrm{ext}}$
Table 2. Surface model parameters.

\begin{tabular}{ll}
\hline$k_{\text {ext }}=0.5$ & extinction coefficient for radiation \\
$\alpha_{\mathrm{sn}, \text { fresh }}^{\text {vis }}=0.95$ & diffuse visible fresh snow albedo \\
$\alpha_{\mathrm{sn}, \text { dif }}=0.65$ & diffuse near-infrared fresh snow albedo \\
$z_{0}^{\mathrm{b}}=0.005 \mathrm{~m}$ & bare soil roughness length \\
$z_{0}^{1}=0.01 \mathrm{~m}$ & ice roughness length \\
$z_{0}^{\mathrm{sn}}=0.0024 \mathrm{~m}$ & snow roughness length \\
$C_{\mathrm{can}}=0.006$ & drag coefficient for fluxes below the canopy \\
$\alpha_{\text {int }}^{\mathrm{W}}=0.2$ & canopy water interception parameter \\
$\alpha_{\mathrm{int}}^{\mathrm{s}}=0.5$ & canopy snow interception parameter \\
$\tau_{\mathrm{W}}=1$ day & canopy water removal timescale \\
$\tau_{\mathrm{s}}=10$ days & canopy snow removal timescale \\
$\rho_{\mathrm{sn}, \min }=50 \mathrm{~kg} \mathrm{~m}^{-3}$ & minimum snow density \\
$\eta_{0}=9 \times 10^{6} \mathrm{Pas}_{\mathrm{T}}$ & reference snow viscosity \\
$k_{\mathrm{T}}=0.06 \mathrm{~K}^{-1}$ & temperature parameter for snow viscosity \\
$k_{\rho}=0.02 \mathrm{~m}^{3} \mathrm{~kg}^{-1}$ & density parameter for snow viscosity \\
$f_{\nabla}=1.7$ & parameter for saturated grid cell fraction \\
\hline
\end{tabular}

(Table 2) (e.g. Otto et al., 2011):

$f_{\mathrm{sv}}=\exp \left[-k_{\mathrm{ext}}\left(L_{\mathrm{ai}}+S_{\mathrm{ai}}\right)\right]$.

The forest albedo is computed as a weighted mean of canopy albedo $\left(\alpha_{\mathrm{can}}\right)$ and albedo of the ground below the canopy $\left(\alpha_{\mathrm{g}}\right)$ :

$\alpha=f_{\mathrm{sv}} \alpha_{\mathrm{g}}+\left(1-f_{\mathrm{sv}}\right) \alpha_{\mathrm{can}}$, forest.

The direct beam sky view factor for forest includes a daily radiation-weighted solar zenith angle $(\mu)$ dependence following Campbell and Norman (1989):

$f_{\mathrm{sv}}^{\mathrm{dir}}=\exp \left[-k_{\mathrm{ext}} \frac{\left(L_{\mathrm{ai}}+S_{\mathrm{ai}}\right)}{\cos \mu}\right]$

The sky view factor for diffuse radiation is derived by fitting the relation given by Verseghy et al. (1993) and is taken to be

$f_{\mathrm{sv}}^{\mathrm{dif}}=\exp \left[-k_{\mathrm{ext}} \frac{\left(L_{\mathrm{ai}}+S_{\mathrm{ai}}\right)}{\cos 45^{\circ}}\right]$.

The albedo of the ground below the canopy, $\alpha_{\mathrm{g}}$, is computed as in Eq. (9). $\alpha_{\text {can }}$ varies between snow-free canopy albedo and snow-covered canopy albedo depending on the canopy fraction covered by snow:

$\alpha_{\text {can }}=f_{\text {can }}^{\mathrm{s}} \alpha_{\text {sn }}^{\mathrm{can}}+\left(1-f_{\text {can }}^{\mathrm{s}}\right) \alpha_{\text {snfree }}^{\mathrm{can}}$.

The canopy fraction covered by snow, $f_{\text {can }}^{\mathrm{s}}$, is described in Sect. 5.1. For $\alpha_{\mathrm{snfree}}^{\mathrm{can}}$ the PFT-specific values derived from MODIS data in Houldcroft et al. (2009) for the TRIFFID PFTs are used and $\alpha_{\mathrm{sn}}^{\mathrm{can}}$ values are taken from Moody et al. (2007) based on MODIS data (Table 5).

Snow albedo is parameterized as a function of the solar zenith angle and a snow ageing factor. The diffuse albedo of 
freshly fallen snow is set to 0.95 in the visible band and to 0.65 in the near-infrared band. The actual albedo of snow for diffuse radiation depends on a snow age factor $f_{\text {age }}$ :

$\alpha_{\mathrm{sn}}^{\mathrm{vis}, \mathrm{dif}}=\alpha_{\mathrm{sn}, \text { fresh }}^{\mathrm{vis,dif}}-0.05 f_{\text {age }}$,

$\alpha_{\mathrm{sn}}^{\mathrm{nir}, \mathrm{dif}}=\alpha_{\mathrm{sn}, \text { fresh }}^{\mathrm{nir,dif}}-0.25 f_{\text {age }}$.

The snow age factor is intended to represent the effect of snow grain size increase on albedo (Warren and Wiscombe, 1980). For simplicity and to account for the fact that a statistical dynamical atmosphere does not resolve single snowfall events but rather returns a smoothly varying daily snowfall rate, $f_{\text {age }}$ is parameterized as a function of skin temperature and snowfall rate as described in Appendix A. If the skin temperature is at melting point, the snow albedo is further reduced by 0.2 to account for the formation of melt ponds.

The direct beam snow albedo is then computed as in Dickinson et al. (1986):

$\alpha_{\mathrm{sn}}^{\mathrm{dir}}=\alpha_{\mathrm{sn}}^{\mathrm{dif}}+0.4 f_{\mu}\left(1-\alpha_{\mathrm{sn}}^{\mathrm{dif}}\right)$,

where the solar zenith angle factor is slightly modified from Dickinson et al. (1986) to correct for the bias highlighted by Gardner and Sharp (2010):

$f_{\mu}=0.5\left(\frac{3}{1+2 \cos \mu}-1\right)$.

\subsection{Surface emissivity}

The broadband emissivity $(\epsilon)$ used to compute the net longwave radiation at the surface is a surface-type-dependent parameter. It is taken to be equal to 0.96 for all vegetation types, 0.9 for bare soil, 0.99 for snow-covered ground and 0.99 for ice (Jin and Liang, 2006; Walters et al., 2014).

\subsection{Aerodynamic resistances}

The aerodynamic resistance, $r_{\mathrm{a}}$, is computed for each surface type accounting for atmospheric stability through a bulk Richardson number following BATS (Dickinson et al., 1986). The drag coefficients for neutral stratification are obtained from boundary layer theory:

$C_{\mathrm{DN}}^{\mathrm{m}}=\kappa^{2}\left[\ln \left(\frac{z_{\mathrm{ref}}-d}{z_{\mathrm{m}}}\right)\right]^{-2}$, drag coefficient for momentum

$C_{\mathrm{DN}}^{\mathrm{h}}=\kappa^{2}\left[\ln \left(\frac{z_{\text {ref }}-d}{z_{\mathrm{m}}}\right) \ln \left(\frac{z_{\mathrm{ref}}-d}{z_{\mathrm{h}}}\right)\right]^{-1}$, drag coefficient for heat and water.

$z_{\text {ref }}$ is a reference height above the surface and $d$ is the zeroplane displacement, the height above the ground at which zero wind speed is achieved, and depends on the surface type. $z_{\mathrm{m}}$ is the roughness length for momentum and is computed as the weighted mean of the roughness length of snow $\left(z_{0}^{\mathrm{sn}}\right)$ and the roughness length of the snow-free surface $\left(z_{0}^{\text {snfree }}\right)$ :

$z_{\mathrm{m}}=f_{\mathrm{sn}} z_{0}^{\mathrm{sn}}+\left(1-f_{\mathrm{sn}}\right) z_{0}^{\mathrm{snfree}}$.

A logarithmic averaging would be more appropriate here (Zeng and Wang, 2007), but for computational efficiency a simple linear weighting is preferred. This simplification does not significantly affect the model results. The snow-covered fraction is given by Eq. (10) for all surface types. For vegetated surfaces, $z_{0}^{\text {snfree }}$ is given by a weighted mean of vegetation $\left(z_{0}^{\mathrm{v}}\right)$ and bare soil $\left(z_{0}^{\mathrm{b}}\right)$ roughness:

$z_{0}^{\text {snfree }}=V z_{0}^{\mathrm{v}}+(1-V) z_{0}^{\mathrm{b}}$,

where the weight $V$ depends on the vegetation state

$V=\frac{L_{\mathrm{ai}}+S_{\mathrm{ai}}}{\left(L_{\mathrm{ai}}+S_{\mathrm{ai}}\right)_{\mathrm{crit}}}$,

and is limited to be lower than 1 . The critical value of $\left(L_{\mathrm{ai}}+S_{\mathrm{ai}}\right)_{\text {crit }}$ is set to 2 . Zeng and Wang (2007) showed that model results are not very sensitive to the formulation of $V$. $z_{0}^{\mathrm{v}}$ is taken as $1 / 10$ of the vegetation height $\left(h_{\mathrm{v}}\right)$ and the displacement $d=0.7 V h_{\mathrm{v}}$. Vegetation height varies over time for each PFT and differs between PFTs (see Eq. 81). For bare soil, snow and ice $d=0$ and the values of $z_{0}$ are given in Table 2 .

In general, the roughness length for heat and water vapour differs from the roughness length for momentum and is defined by Garratt (1994); Milly and Shmakin (2002)

$\ln \left(\frac{z_{\mathrm{m}}}{z_{\mathrm{h}}}\right)=2$.

$z_{\mathrm{h}}$ is therefore almost an order of magnitude smaller than $z_{\mathrm{m}}$.

Although the surface energy balance equation in PALADYN is solved with a daily time step, which implies that the diurnal cycle in atmospheric stability can not be resolved by the model, the inclusion of a simple Richardson number dependence based on daily mean temperatures in the computation of the drag coefficients significantly improves the simulated surface energy fluxes when the stratification is unstable. The bulk Richardson number is calculated as (Dickinson et al., 1986):

$R_{\mathrm{i}}=g z_{\text {ref }} \frac{\left(1-T_{*} / T_{\mathrm{a}}\right)}{V_{\mathrm{a}}^{2}+1}$,

where $g$ is the acceleration due to gravity and $V_{\mathrm{a}}$ is the wind speed at the reference level $z_{\text {ref. }}$. The drag coefficients for the unstable case $\left(R_{\mathrm{i}}<0\right)$ are then adjusted to account for atmospheric stability:

$C_{\mathrm{D}}^{\mathrm{m} / \mathrm{h}}=C_{\mathrm{DN}}^{\mathrm{m} / \mathrm{h}}\left(1+24.5 \sqrt{-C_{\mathrm{DN}}^{\mathrm{m} / \mathrm{h}} R_{\mathrm{i}}}\right) R_{\mathrm{i}}<0$. 
Finally, the aerodynamic resistance for sensible and latent heat flux is given by

$r_{\mathrm{a}}=\frac{1}{C_{\mathrm{D}}^{\mathrm{h}} V_{\mathrm{a}}}$.

The aerodynamic resistance for the transfer of heat and water between the ground and the canopy is parameterized as

$r_{\mathrm{a}, \mathrm{can}}=\frac{1-\exp \left[-\left(L_{\mathrm{ai}}+S_{\mathrm{ai}}\right)\right]}{C_{\mathrm{can}} V_{\mathrm{a}}}$.

The leaf and stem area index factor insures that $r_{\mathrm{a} \text {,can }}$ tends to zero when vegetation is vanishing. The values of the drag coefficient $C_{\text {can }}$ is given in Table 2 .

\subsection{Surface resistance to water vapour fluxes}

Additionally to the aerodynamic resistances, the flux of water vapour from the ground or canopy is subject to additional resistances. For evaporation from bare soil, this surface resistance is represented in terms of a $\beta_{\mathrm{s}}$ factor. Different parameterizations of $\beta_{\mathrm{s}}$ have been proposed to be used in global climate models (e.g. Mahfouf and Noilhan, 1991). The model results, in particular the geographic distribution and extent of modelled bare soil, are strongly dependent on the formulation of the $\beta_{\mathrm{s}}$ factor. Thus, various surface resistance formulations for bare soil evaporation are implemented in PALADYN with the default $\beta_{\mathrm{s}}$ depending on top soil moisture $\left(\theta_{1}\right)$ and field capacity $\left(\theta_{\mathrm{fc}}\right)$ following Lee and Pielke (1992):

$\beta_{\mathrm{s}}= \begin{cases}\frac{1}{4}\left[1-\cos \left(\pi \frac{\theta_{1}}{\theta_{\mathrm{fc}}}\right)\right]^{2} & \theta_{1}<\theta_{\mathrm{fc}} \\ 1 & \theta_{1} \geq \theta_{\mathrm{fc}} .\end{cases}$

The resistance for transpiration of water through the leaf stomata is coupled to the uptake of carbon during photosynthesis and is simply the inverse of the canopy conductance calculated by the photosynthesis module (Sect. 6.1) after conversion to units of $\mathrm{ms}^{-1}$ :

$r_{\mathrm{s}}=\frac{1}{g_{\text {can }}}$.

Evaporation and sublimation from the canopy and sublimation from snow and ice are assumed to occur without surface resistance $\left(r_{\mathrm{s}}=0\right.$ and $\left.\beta_{\mathrm{s}}=1\right)$.

\section{Snow and soil temperature}

The heat transfer in the snow-soil column is represented by a one-dimensional heat diffusion equation:

$c \frac{\partial T_{\mathrm{s}}}{\partial t}=\frac{\partial}{\partial z}\left[\lambda \frac{\partial T_{\mathrm{s}}}{\partial z}\right]$.

Equation (33) assumes that the lateral heat transport and vertical heat transport other than by conduction are small and can be neglected. Other models include, for example, the vertical heat advection by the water penetrating into the soil (e.g. Cox et al., 1999). Equation (33) also assumes that there are no heat sources inside the soil column. Heat generated by organic matter decomposition is an example of internally generated heat (e.g. Khvorostyanov et al., 2008). In Eq. (33), c is the volumetric heat capacity and $\lambda$ is the thermal conductivity of soil-snow. Equation (33) is solved with the ground heat flux as top boundary condition and zero heat flux at the bottom of the soil column. Eventually the deep permafrost model of Willeit and Ganopolski (2015) is going to be coupled to PALADYN with the geothermal heat flux as the bottom boundary condition. The numerical solution of Eq. (33) follows the fully implicit formulation in Oleson et al. (2013). The snow/soil temperature profile is calculated first without phase change and then readjusted for phase change following Oleson et al. (2013). If the new temperature of snow or of a soil layer containing frozen water is greater than $0^{\circ} \mathrm{C}$, the excess energy is used to melt snow or frozen soil water. If all snow is melting during one time step and excess energy is remaining, this energy is added to the top soil layer. If soil temperature drops below $0^{\circ} \mathrm{C}$, soil water starts to freeze. $\mathrm{Ob}$ servations show that liquid water exists in the soil at temperatures well below $0{ }^{\circ} \mathrm{C}$ because of adsorption forces, capillarity and ground heterogeneity (e.g. Williams and Smith, 1989) and the presence of solutes (e.g. Watanabe and Mizoguchi, 2002). To allow liquid water to coexist with ice below $0^{\circ} \mathrm{C}$, a freezing point depression is included in the model and the maximum liquid water content for soil temperatures $T_{\mathrm{S}}$ below $T_{0}=273.15 \mathrm{~K}$ is formulated as (e.g. Cox et al., 1999; Niu and Yang, 2006; Ekici et al., 2014):

$w_{\mathrm{w}}^{\max }=\Delta z \rho_{\mathrm{w}} \theta_{\mathrm{sat}}\left[\frac{L_{\mathrm{f}}\left(T_{\mathrm{s}}-T_{0}\right)}{g T_{\mathrm{s}} \psi_{\mathrm{sat}}}\right]^{-1 / b}$,

where $\Delta z$ is the layer thickness, $\rho_{\mathrm{w}}$ the density of water, $\theta_{\mathrm{sat}}$ the porosity of the soil, $L_{\mathrm{f}}$ the latent heat of fusion of water, $\psi_{\text {sat }}$ is the matric potential at saturation and $b$ the ClappHornberger parameter (Sect. 5.4).

\subsection{Snow and soil thermal properties}

In winter, snow plays a crucial role in insulating the ground below from the cold air temperatures. A realistic parameterization of snow thermal properties is therefore fundamental to simulate frozen soil dynamics. In particular, PALADYN is very sensitive to the parameterization of snow thermal conductivity. Hence, several snow thermal conductivity formulations that are all dependent on snow density are included in the model (Yen, 1981; Jordan, 1991; Riche and Schneebeli, 2013). The default snow thermal conductivity is from Riche and Schneebeli (2013):

$\lambda_{\mathrm{sn}}=\lambda_{\mathrm{a}}-1.06 \times 10^{-5} \rho_{\mathrm{sn}}+3 \times 10^{-6} \rho_{\mathrm{sn}}^{2}$.

$\lambda_{\mathrm{a}}$ is the air thermal conductivity and the snow density $\rho_{\mathrm{sn}}$ is described in detail in Sect. 5.2. 
Table 3. Soil model parameters.

$\begin{array}{ll}c_{\mathrm{S}}=2.3 \times 10^{6} \mathrm{~J} \mathrm{~m}^{-3} \mathrm{~K}^{-1} & \text { volumetric heat capacity of soil } \\ \lambda_{\mathrm{s}}=5.0 \mathrm{~W} \mathrm{~m}^{-1} \mathrm{~K}^{-1} & \text { soil heat conductivity at saturation } \\ \lambda_{\mathrm{dry}}=0.2 \mathrm{~W} \mathrm{~m}^{-1} \mathrm{~K}^{-1} & \text { dry soil heat conductivity } \\ \theta_{\mathrm{sat}}=0.43 \mathrm{~m}^{3} \mathrm{~m}^{-3} & \text { soil porosity } \\ \theta_{\mathrm{fc}}=0.25 \mathrm{~m}^{3} \mathrm{~m}^{-3} & \text { volumetric soil moisture at field capacity } \\ \theta_{\mathrm{wp}}=0.14 \mathrm{~m}^{3} \mathrm{~m}^{-3} & \text { volumetric soil moisture at wilting point } \\ \psi_{\mathrm{sat}}=-0.2 \mathrm{~m} \mathrm{~m}^{-2} & \text { soil matric potential at saturation } \\ k_{\mathrm{Sat}}=520 \mathrm{~kg} \mathrm{~m}^{-1} \mathrm{day}^{-1} & \text { soil hydraulic conductivity at saturation } \\ b=6 & \text { Clapp-Hornberger parameter }\end{array}$

The volumetric heat capacity of snow depends on snow density and specific heat capacity of ice $\left(C_{\mathrm{i}}\right)$ :

$c_{\mathrm{sn}}=C_{\mathrm{i}} \rho_{\mathrm{sn}}$.

Soil heat capacity is a volume-weighted mean of dry soil and liquid and frozen water:

$c=\left(1-\theta_{\mathrm{sat}}\right) c_{\mathrm{s}}+\theta_{\mathrm{w}} \rho_{\mathrm{w}} C_{\mathrm{w}}+\theta_{\mathrm{i}} \rho_{\mathrm{i}} C_{\mathrm{i}}$,

where $c_{\mathrm{s}}$ is the volumetric heat capacity of dry soil (Table 3 ), $\theta_{\mathrm{w}}$ and $\theta_{\mathrm{i}}$ are the volumetric soil liquid and frozen water contents, respectively, $C_{\mathrm{w}}$ is the specific heat capacity of water and $\rho_{\mathrm{i}}$ is the density of ice.

Soil heat conductivity is a combination of heat conductivity of water, ice and dry soil following Farouki (1981):

$\lambda=K \lambda_{\text {sat }}+(1-K) \lambda_{\text {dry }}$,

with

$\lambda_{\text {sat }}=\lambda_{\mathrm{s}}^{1-\theta_{\mathrm{sat}}} \lambda_{\mathrm{w}}^{\frac{\theta_{\mathrm{w}}}{\theta} \theta_{\mathrm{sat}}} \lambda_{\mathrm{i}}^{\frac{\theta_{\mathrm{i}}}{\theta} \theta_{\mathrm{sat}}}$,

where $\theta$ is the total (liquid plus frozen) volumetric soil water content. The original logarithmic formulation of the Kersten number $(K)$ is approximated by a linear function of relative soil moisture:

$K=\left\{\begin{array}{ll}\frac{1}{1-0.35}\left(\frac{\theta}{\theta_{\mathrm{sat}}}-0.35\right) & T_{\mathrm{s}} \geq 0{ }^{\circ} \mathrm{C} \\ \frac{\theta}{\theta_{\mathrm{sat}}} & T_{\mathrm{s}}<0^{\circ} \mathrm{C}\end{array}\right.$.

$K$ is limited to be between 0 and $1 . \lambda_{\mathrm{w}}$ and $\lambda_{\mathrm{i}}$ are the thermal conductivities of water and ice, respectively. $\lambda_{\mathrm{s}}$ and $\lambda_{\text {dry }}$ are globally uniform soil parameters (Table 3 ). Alternatively, the values can be chosen to be dependent on soil texture and soil organic carbon content as described in Appendix B. The inclusion of variable $\lambda_{\mathrm{s}}$ and $\lambda_{\text {dry }}$ does not fundamentally affect the main model results; hence, for computational efficiency the parameters are taken to be uniform in space and constant in time by default.

\section{Hydrology}

\subsection{Canopy water}

Re-evaporation of canopy-intercepted water contributes significantly to the total water flux from the surface to the atmo- sphere (e.g. Dirmeyer et al., 2006). Therefore, PALADYN includes a representation of rain and snow intercepted by vegetation. Rain is assumed to be intercepted only by trees while snow is intercepted by all PFTs. The prognostic equations for canopy liquid water $\left(w_{\mathrm{can}}^{\mathrm{W}}\right)$ and snow $\left(w_{\mathrm{can}}^{\mathrm{s}}\right)$ are similar and written in terms of canopy interception, canopy evaporation/sublimation and a canopy water removal term as

$\frac{d w_{\mathrm{can}}^{\mathrm{w} / \mathrm{s}}}{\mathrm{d} t}=I_{\mathrm{can}}^{\mathrm{W} / \mathrm{s}}-E_{\mathrm{can}}^{\mathrm{w} / \mathrm{s}}-\frac{w_{\mathrm{can}}^{\mathrm{w} / \mathrm{s}}}{\tau_{\mathrm{w} / \mathrm{s}}}$.

Canopy interception and evaporation are given by

$\begin{aligned} I_{\mathrm{can}}^{\mathrm{W} / \mathrm{s}} & =\alpha_{\mathrm{int}}^{\mathrm{w} / \mathrm{s}} P_{\mathrm{r} / \mathrm{s}}\left(1-\exp \left[-k_{\mathrm{ext}}\left(L_{\mathrm{ai}}+S_{\mathrm{ai}}\right)\right]\right), \\ E_{\mathrm{can}}^{\mathrm{w} / \mathrm{s}} & =\frac{\rho_{\mathrm{a}}}{r_{\mathrm{a}}}\left(q_{\mathrm{sat}}\left(T_{*}\right)-q_{\mathrm{a}}\right) f_{\mathrm{can}}^{\mathrm{w} / \mathrm{s}} .\end{aligned}$

$P_{\mathrm{r}}$ is the rain rate and $P_{\mathrm{s}}$ the snowfall rate. $\alpha_{\mathrm{int}}^{\mathrm{w}}$ and $\alpha_{\mathrm{int}}^{\mathrm{s}}$ are interception factors (Table 2). The wet canopy fraction $f_{\text {can }}^{\mathrm{w}}$ and the snow-covered canopy fraction $f_{\text {can }}^{\mathrm{s}}$ are assumed to increase linearly with $w_{\text {can }}^{\mathrm{w}}$ and $w_{\text {can }}^{\mathrm{s}}$, respectively, up to a maximum water and snow amount that the canopy can hold, $w_{\text {can }}^{\max }=0.2\left(L_{\mathrm{ai}}+S_{\mathrm{ai}}\right)\left(\right.$ e.g Verseghy et al., 1993). $\tau_{\mathrm{w}}$ and $\tau_{\mathrm{s}}$ are the water and snow canopy removal timescales, respectively (Table 2). Negative canopy evaporation, that is dew deposition, is inhibited. If skin temperature is greater than $0^{\circ} \mathrm{C}$, all snow is removed from the canopy and added to the snow layer on the ground. Finally $E_{\mathrm{can}}=E_{\mathrm{can}}^{\mathrm{w}}+E_{\mathrm{can}}^{\mathrm{s}}$ is diagnosed and used in the solution of the surface energy balance equation (Eq. 1). The rate of rain and snow reaching the ground is then derived as

$P_{\mathrm{r} / \mathrm{s}, \mathrm{g}}=P_{\mathrm{r} / \mathrm{s}}-E_{\mathrm{can}}^{\mathrm{W} / \mathrm{s}}-\frac{\mathrm{d} w_{\mathrm{can}}^{\mathrm{w} / \mathrm{s}}}{\mathrm{d} t}$.

The area-weighted $P_{\mathrm{r} / \mathrm{s}, \mathrm{g}}$ over the vegetated and bare soil surface tiles are then used as input to the surface hydrology module.

\subsection{Snow}

The snow water equivalent evolution of the single snow layer is determined by the snowfall rate $P_{\mathrm{s}, \mathrm{g}}$, the snowmelt rate $M_{\mathrm{s}}$ and sublimation $E_{\mathrm{s}}$ :

$\frac{\mathrm{d} w_{\mathrm{sn}}}{\mathrm{d} t}=P_{\mathrm{s}, \mathrm{g}}-M_{\mathrm{s}}-E_{\mathrm{s}}$.

To prevent an indefinite accumulation of snow, $w_{\mathrm{sn}}$ is limited to be below $w_{\text {sn,crit }}=1000 \mathrm{~kg} \mathrm{~m}^{-2}$ and the snow excess is added to frozen water runoff.

The density of snow is important because it determines the thickness of snow and hence influences surface albedo and surface roughness and because it controls the thermal properties of snow (Sect. 4.1). The parameterization of snow density is based partly on Anderson (1976) and Pitman et al. 
(1991). The density of freshly fallen snow is temperature dependent following Anderson (1976):

$$
\begin{gathered}
\rho_{\mathrm{sn}, \text { fresh }}=\rho_{\mathrm{sn}, \min }+1.7\left(T_{\mathrm{a}}-T_{0}+15\right)^{1.5} \\
\text { for } T_{0}-15<T_{\mathrm{a}}<T_{0}+2 .
\end{gathered}
$$

$\rho_{\text {sn,min }}$ is the minimum snow density (Table 2). The effect of self-loading on snow compaction is taken into account using the relation proposed by Kojima (1967) as implemented in Pitman et al. (1991) and the prognostic equation for snow density accounting also for the density of freshly fallen snow is written as (Pitman et al., 1991)

$\frac{\mathrm{d} \rho_{\mathrm{sn}}}{\mathrm{d} t}=\frac{0.5 g \rho_{\mathrm{sn}} w_{\mathrm{sn}}}{\eta}+P_{\mathrm{s}, \mathrm{g}} \frac{\rho_{\mathrm{sn}, \text { fresh }}-\rho_{\mathrm{sn}}}{w_{\mathrm{sn}}}$,

where $\eta$ is the viscosity depending both on the load and temperature:

$\eta=\eta_{0} \cdot \exp \left[k_{\mathrm{T}}\left(T_{0}-T_{\mathrm{sn}}\right)+k_{\rho} \rho_{\mathrm{sn}}\right]$.

The values of the parameters $\eta_{0}, k_{\mathrm{T}}$ and $k_{\rho}$ are given in Table 2. The effects of snow metamorphism and snow melting on snow density are neglected. Snow thickness is then computed as

$h_{\mathrm{sn}}=\frac{w_{\mathrm{sn}}}{\rho_{\mathrm{sn}}}$.

\subsection{Surface runoff and infiltration}

Subgrid-scale surface hydrology is represented using a TOPMODEL approach (Beven and Kirkby, 1979) as implemented in Niu et al. (2005). The fraction of a grid cell that is assumed to be at saturation, $f_{\text {sat }}$, is determined by the grid cell mean water table position $\left(z_{\nabla}\right)$ and the spatially varying maximum saturated fraction $f_{\text {sat }}^{\max }$ computed by Stocker et al. (2014) from the compound topographic index (CTI) derived from the high-resolution ETOPO1 topography as (Niu et al., 2005)

$f_{\mathrm{sat}}=f_{\mathrm{sat}}^{\max } e^{-f_{\nabla} z_{\nabla}}$.

$f_{\nabla}$ is a parameter whose value is given in Table 2 . If the surface is snow free, the wetland fraction is set equal to the saturated fraction $\left(f_{\text {wet }}=f_{\text {sat }}\right)$, while it is set to zero otherwise. The grid cell mean water table depth is estimated directly from the volumetric water content in the soil column, the peat fraction $\left(f_{\text {peat }}\right)$ and the water table in peat $\left(z_{\nabla}^{\text {peat }}\right)$ as

$z_{\nabla}=\left(1-f_{\text {peat }}\right)\left(h_{\text {soil }}-\sum_{l} \frac{\theta_{l}}{\theta_{\text {sat }, l}} \Delta z_{l}\right)+f_{\text {peat }} z_{\nabla}^{\text {peat }}$.

$h_{\text {soil }}$ is the soil column depth and the sum is over all soil layers. The peat water table is assumed to follow the grid cell mean seasonal water table variations but with an amplitude limited to the acrotelm thickness (Sect. 6.3.1). The maximum soil infiltration rate is then computed from the saturated hydraulic conductivity $\left(k_{\mathrm{sat}}\right)$ assuming that infiltration can occur only in the unsaturated part of the grid cell:

$q_{\text {inf }}^{\max }=k_{\text {sat }}\left(1-f_{\text {sat }}\right)$.

Surface runoff is then calculated assuming that all liquid water that reaches the surface is rooted directly to runoff over the saturated fraction of the grid cell and considering that the maximum infiltration rate can not be exceeded:

$$
\begin{gathered}
R_{\mathrm{W}}=f_{\mathrm{sat}}\left(P_{\mathrm{r}, \mathrm{g}}+M_{\mathrm{s}}\right)+\left(1-f_{\mathrm{sat}}\right) \\
\cdot \max \left(0, P_{\mathrm{r}, \mathrm{g}}+M_{\mathrm{s}}-q_{\mathrm{inf}}^{\max }\right) .
\end{gathered}
$$

The actual soil infiltration rate is then computed as

$q_{\text {inf }}=P_{\mathrm{r}, \mathrm{g}}+M_{\mathrm{s}}-R_{\mathrm{w}}$.

\subsection{Soil hydrology}

Water in the soil is assumed to be limited to flow in the vertical direction. Making use of the conservation of mass, the change in volumetric water content over time is then given by the vertical divergence of the water flux and a sink term from soil water extraction by evapotranspiration $(e)$ :

$\rho_{\mathrm{w}} \Delta z_{l} \frac{d \theta_{\mathrm{w}, l}}{\mathrm{~d} t}=q_{l-1}-q_{l}-e_{l}$,

where $l$ is the soil layer index. This equation is solved with infiltration $\left(q_{\text {inf }}\right)$ as top boundary condition and a free drainage bottom boundary condition, i.e. the water flux at the bottom of the soil column $\left(q_{\text {drain }}\right)$ is set equal to the bottom hydraulic conductivity. The soil water flux $q$ is expressed by Darcy's law:

$q=k \frac{\partial(\psi-z)}{\partial z}$,

where $k$ is the hydraulic conductivity and $\psi$ is the matric potential. $z$ is the vertical coordinate and is positive downwards from the surface. The numerical solution of Eq. (55) follows the formulation in Oleson et al. (2013).

The hydraulic conductivity and the matric potential are soil hydraulic properties dependent on soil texture and volumetric soil water following Clapp and Hornberger (1978):

$$
\begin{gathered}
\psi=\psi_{\text {sat }}\left(\frac{\theta_{\mathrm{w}}}{\theta_{\text {sat }}}\right)^{-b} \\
k=k_{\text {sat }}\left(\frac{\theta_{\mathrm{w}}}{\theta_{\text {sat }}}\right)^{2 b+3} .
\end{gathered}
$$

Similarly to the discussion on soil thermal parameters in Sect. 4.1, hydraulic conductivity and matric potential at saturation, $k_{\text {sat }}$ and $\psi_{\text {sat }}$, and the Clapp and Hornberger parameter $b$ are set to global uniform values by default (Table 3 ). However, a soil texture and soil organic matter content dependent formulation of $k_{\text {sat }}, \psi_{\text {sat }}$ and $b$ is also available (Appendix B). 


\section{Biogeochemistry and vegetation dynamics}

\subsection{Photosynthesis}

Daily photosynthesis is modelled following the general light use efficiency model described in Haxeltine and Prentice (1996a, b) as implemented in the LPJ dynamic vegetation model (Sitch et al., 2003), with some modifications. Compared to other models it has the advantage that it computes daily integrated photosynthesis without the need to explicitly resolve the diurnal cycle and therefore saves computing time. It also makes it convenient to be coupled to the physical PALADYN components, which are also integrated with a daily time step. Daily gross photosynthesis is computed from a light-limited $\left(J_{\mathrm{E}}\right)$ and a RuBisCO-limited rate $\left(J_{\mathrm{C}}\right)$ as

$A_{\mathrm{g}}=\frac{J_{\mathrm{E}}+J_{\mathrm{C}}-\sqrt{\left(J_{\mathrm{E}}+J_{\mathrm{C}}\right)^{2}-4 \theta_{\mathrm{r}} J_{\mathrm{E}} J_{\mathrm{C}}}}{2 \theta_{\mathrm{r}}} \beta_{\theta}$.

$J_{\mathrm{E}}=c_{1} \cdot \mathrm{APAR}$,

$J_{\mathrm{C}}=c_{2} \cdot V_{\mathrm{m}}$.

$\theta_{\mathrm{r}}$ is a shape parameter and APAR is the absorbed photosynthetically active radiation computed as

$\operatorname{APAR}=0.5 \mathrm{SW}^{\downarrow} \alpha_{\mathrm{a}}\left(1-e^{-k_{\mathrm{ext}} L_{\mathrm{ai}}}\right) \Delta t\left(1-\alpha_{\text {leaf }}\right) c_{\mathrm{q}}$.

Half of the downwelling shortwave radiation is assumed to be in the photosynthetically active wavelength range, $\alpha_{\mathrm{a}}$ accounts for reductions in PAR utilization efficiencies in natural ecosystems, the factor $1-e^{-k_{\mathrm{ext}} L_{\mathrm{ai}}}$ scales to the canopy, $\alpha_{\text {leaf }}$ is the leaf albedo in the PAR range, $\Delta t$ is the length of day in seconds and $c_{\mathrm{q}}$ is a conversion factor from $\mathrm{J} \mathrm{m}^{-2}$ to mol m${ }^{-2}$. Parameter values are given in Table 4 and more details on the formulation of $c_{1}$ and $c_{2}$ and the maximum daily rate of net photosynthesis $V_{\mathrm{m}}$ are given in Appendix C.

Leaf respiration, $R_{\mathrm{d}}$, is scaled to $V_{\mathrm{m}}$ as

$R_{\mathrm{d}}=a_{\mathrm{C} 3 / 4} V_{\mathrm{m}} \beta_{\theta}$,

and daily net assimilation is then calculated as

$A_{\mathrm{n}}=A_{\mathrm{g}}-R_{\mathrm{d}}$

Daytime net assimilation can then be computed by adding nighttime respiration:

$A_{\mathrm{nd}}=A_{\mathrm{n}}+\left(1-\frac{d_{\mathrm{h}}}{24}\right) R_{\mathrm{d}}$.

$\beta_{\theta}$ is a soil-moisture-limiting factor:

$\beta_{\theta}=\sum_{l} \frac{\theta_{\mathrm{w}, l}-\theta_{\mathrm{wp}}}{\theta_{\mathrm{fc}}-\theta_{\mathrm{wp}}} r_{l}$,

$\theta_{\mathrm{wp}}$ and $\theta_{\mathrm{fc}}$ are the soil moisture values at wilting point and field capacity, respectively. $r_{l}$ is the fraction of roots in layer $l$
(Sect. 6.2.2). If the soil temperature of layer $l$ is below $-2{ }^{\circ} \mathrm{C}$, the corresponding term in Eq. (66) is set to 0.

$c_{1}$ and $c_{2}$ depend on the intercellular partial pressure of $\mathrm{CO}_{2}\left(p_{\mathrm{i}}\right)$, which is proportional to the atmospheric $\mathrm{CO}_{2}$ concentration $\left(p_{\mathrm{a}}\right)$ :

$p_{\mathrm{i}}=\lambda_{\mathrm{c}} p_{\mathrm{a}}$.

In LPJ, $\lambda_{c}$ is computed iteratively from potential and actual evapotranspiration (Sitch et al., 2003). To reduce the computation cost and in light of recent developments, in PALADYN $\lambda_{\mathrm{c}}$ is derived from the optimal stomatal conductance model (Medlyn et al., 2011), which predicts that canopy conductance for water vapour $g_{\text {can }}$ is given by

$g_{\text {can }}=g_{0}+\left(1+\frac{g_{1}}{\sqrt{\mathrm{VPD}}}\right) \frac{A_{\mathrm{nd}}}{c_{\mathrm{a}}}$.

VPD is the vapour pressure deficit between leaf surface and ambient air. Since $\mathrm{CO}_{2}$ has to diffuse trough the stomata into the leaf interior before being fixed by photosynthesis and at the same time water vapour diffuses through the stomata from the leaf interior to the canopy air, $g_{\text {can }}$ and $A_{\text {nd }}$ are also related by

$g_{\text {can }}=g_{0}+1.6 \frac{A_{\text {nd }}}{c_{\mathrm{a}}-c_{\mathrm{i}}}$.

$c_{\mathrm{a}}$ and $c_{\mathrm{i}}$ are the atmospheric and intercellular $\mathrm{CO}_{2}$ mole fractions and $g_{0}$ is a minimum canopy conductance:

$g_{0}=g_{\min }\left(1-e^{-k_{\mathrm{ext}} L_{\mathrm{ai}}}\right) \beta_{\theta}$.

The values of $g_{\min }$ are given in Table 5. From Eqs. (68) and (69), $\lambda_{c}$ can simply be derived (e.g. Medlyn et al., 2011):

$\lambda_{\mathrm{c}}=1-\frac{1.6}{1+g_{1} / \sqrt{\mathrm{VPD}}}$.

To a first approximation, the values of $g_{1}$ are taken to be constant PFT-specific parameters (Table 5) based on the data reported in Lin et al. (2015). As will be shown in Sect. 6.5, based on a simple model, the ratio of $c_{\mathrm{i}}$ and $c_{\mathrm{a}}$ is also the main parameter determining the carbon isotopic discrimination during photosynthesis. Therefore, the PFT-specific discrimination is used as an additional constraint on $g_{1}$ values.

Finally, maintenance respiration and growth respiration are computed and net primary production (NPP) is derived as in Sitch et al. (2003).

\subsection{Vegetation dynamics}

There are a number of existing dynamic global vegetation models spanning a large range of different approaches of varying complexity. The appropriate model complexity for PALADYN, balancing low computational expenses and a realistic representation of continental-scale vegetation dynamics, is represented by the top-down modelling approach of 
Table 4. Photosynthesis model parameters (Sitch et al., 2003).

\begin{tabular}{lll}
\hline$\theta_{\mathrm{r}}$ & 0.7 & co-limitation parameter \\
$\alpha_{\text {leaf }}$ & 0.17 & leaf albedo in PAR range \\
$\alpha_{\mathrm{a}}$ & 0.5 & fraction of PAR assimilated at ecosystem level \\
$c_{\mathrm{q}}$ & $4.6 \times 10^{-6} \mathrm{~mol} \mathrm{~J}^{-1}$ & conversion factor for solar radiation at $550 \mathrm{~nm}$ \\
$a_{\mathrm{C} 3}$ & 0.015 & leaf respiration as a fraction of RuBisCO capacity in C3 plants \\
$a_{\mathrm{C} 4}$ & 0.02 & leaf respiration as a fraction of RuBisCO capacity in C4 plants \\
\hline
\end{tabular}

the TRIFFID dynamic global vegetation model (Cox, 2001; Clark et al., 2011). Another main advantage of this type of model is that it does not require interannual climate variability, which can not be provided by a statistical-dynamical atmosphere model like CLIMBER. The PALADYN dynamic vegetation scheme is therefore based on TRIFFID. The model distinguishes five plant functional types: broadleaved trees, needleleaved trees, C3 and C4 grass and shrubs. Vegetation carbon $C_{\mathrm{v}}$ and fractional area coverage $v$ of each PFT $i$ are described by a coupled system of first order differential equations based on the Lotka-Volterra approach for modelling competition between species:

$$
\begin{aligned}
& \frac{\mathrm{d} C_{\mathrm{v}, i}}{\mathrm{~d} t}=\left(1-\lambda_{\mathrm{NPP}, i}\right) \mathrm{NPP}_{i}-\Lambda_{\mathrm{loc}, i}, \\
& \frac{\mathrm{d} v_{i}}{\mathrm{~d} t}=\frac{\lambda_{\mathrm{NPP}, i} \mathrm{NPP}_{i}}{C_{\mathrm{v}, i}} v_{i, *}\left(1-\sum_{j} c_{i j} v_{j}\right)-\gamma_{\nu, i} v_{i, *} .
\end{aligned}
$$

$v_{i, *}=\max \left(v_{i}, v_{\text {seed }}\right)$, where $v_{\text {seed }}$ is a small seeding fraction used to ensure that a PFT is always seeded (Table 6). $\lambda_{\text {NPP }}$ is a factor determining the partitioning of NPP between increase of vegetation carbon of the existing vegetated area (Eq. 72) and spreading of the given PFT (Eq. 73) and is given by

$$
\lambda_{\mathrm{NPP}}= \begin{cases}0 & L_{\mathrm{ai}, \mathrm{b}}<L_{\mathrm{ai}}^{\min } \\ \frac{L_{\mathrm{a} i, \mathrm{~b}}-L_{\mathrm{ai}}^{\min }}{L_{\mathrm{ai}}^{\max }-L_{\mathrm{ai}}^{\min }} & L_{\mathrm{ai}}^{\min } \leq L_{\mathrm{ai}, \mathrm{b}} \leq L_{\mathrm{ai}}^{\max } \\ 1 & L_{\mathrm{ai}, \mathrm{b}}>L_{\mathrm{ai}}^{\max } .\end{cases}
$$

$L_{\mathrm{ai}, \mathrm{b}}$ is the balanced leaf area index that would be reached if the plant was in full leaf and $L_{\mathrm{ai}}^{\mathrm{min}}$ and $L_{\mathrm{ai}}^{\mathrm{max}}$ are PFT-specific parameters (Table 5). $\Lambda_{\text {loc }}$ is the local litterfall rate:

$\Lambda_{\mathrm{loc}}=\Lambda_{\mathrm{l}}+\gamma_{\mathrm{r}} C_{\mathrm{v}, \mathrm{r}}+\gamma_{\mathrm{s}} C_{\mathrm{v}, \mathrm{s}}$.

Litterfall from leaf turnover is given by $\Lambda_{1}=\gamma_{1} C_{\mathrm{v}, 1}$ for evergreen plants and is computed from the phenological status (Sect. 6.2.1) for deciduous plants. The $\gamma$ values are PFTdependent turnover rates of leaf, root and stem carbon (Table 5). Vegetation carbon $C_{\mathrm{v}}$ is directly related to the balanced leaf area index through the relations of leaf $\left(C_{\mathrm{v}, 1}\right)$, root $\left(C_{\mathrm{v}, \mathrm{r}}\right)$ and stem $\left(C_{\mathrm{v}, \mathrm{s}}\right)$ carbon to $L_{\mathrm{ai}, \mathrm{b}}$ :

$C_{\mathrm{v}, 1}=\frac{L_{\mathrm{ai}, \mathrm{b}}}{\mathrm{SLA}}$,
$C_{\mathrm{v}, \mathrm{r}}=C_{\mathrm{v}, 1}$,

$C_{\mathrm{v}, \mathrm{s}}=a_{\mathrm{wl}} L_{\mathrm{ai}, \mathrm{b}}^{b_{\mathrm{wl}}}$

$C_{\mathrm{v}}=C_{\mathrm{v}, 1}+C_{\mathrm{v}, \mathrm{r}}+C_{\mathrm{v}, \mathrm{s}}$.

SLA is the specific leaf area (one-sided leaf area per leaf carbon mass) and is PFT dependent following Kattge et al. (2011) (Table 5). $a_{\mathrm{wl}}$ is a PFT-specific allometric coefficient (Table 5). In TRIFFID, a value of $b_{\mathrm{wl}}=5 / 3$ is used (Cox, 2001), although Enquist et al. (1998) suggest $b_{\mathrm{wl}}=4 / 3$. In PALADYN, $b_{\mathrm{wl}}=1$ is assumed, which greatly simplifies the solution of Eq. (72), and the $a_{\mathrm{wl}}$ values are adjusted accordingly to compensate for the change in $b_{\mathrm{wl}}$. The competition coefficients, $c_{i j}$, represent the impact of vegetation type $j$ on the vegetation type of interest $i$. TRIFFID is based on a tree-shrub-grass dominance hierarchy with dominant types $i$ limiting the expansion of subdominant types $j\left(c_{j i}=1\right)$, but not vice versa $\left(c_{i j}=0\right)$. While in TRIFFID the tree types and grass types co-compete with competition coefficients dependent on their relative heights, in PALADYN they compete only based on their NPP $\left(c_{i j}=0.5\right.$ and $\left.c_{j i}=0.5\right)$. Additionally, in PALADYN we implemented a dependence of the competition coefficients on bioclimatic limits, i.e. the coldest month temperature $\left(T_{\mathrm{cmon}}^{\mathrm{min} / \mathrm{max}}\right)$ and growing degree days $\left(\operatorname{gdd}_{\min }\right)$ as given in Table 5 . In a given grid cell, PFTs outside of the bioclimatic limits are not competitive and will be dominated by other PFTs, regardless of the tree-shrub-grass dominance.

The last term in Eq. (73) represents vegetation disturbance. In TRIFFID, the disturbance rate $\gamma_{v}$ is taken to be a constant PFT-specific parameter. In reality, on a global scale, disturbance is mainly caused by fire, which shows a strong dependence on climatic conditions and fuel availability (e.g. Thonicke et al., 2010). We therefore introduce a simple parameterization for fire disturbance based on top soil moisture and aboveground biomass loosely following Reick et al. (2013) and Arora and Boer (2005):

$$
\begin{aligned}
& \gamma_{v}=\gamma_{v, \text { min }}+\frac{1}{\tau_{\text {fire }}} \max \left(0, \frac{\theta_{\text {crit }}-\theta_{1}}{\theta_{\text {crit }}}\right) \\
& \cdot \max \left(0, \min \left(1, \frac{C_{\mathrm{v}, \mathrm{ag}}-C_{\mathrm{v}, \text { low }}}{C_{\mathrm{v}, \text { high }}-C_{\mathrm{v}, \text { low }}}\right)\right) .
\end{aligned}
$$

$\gamma_{\nu, \text { min }}$ is a minimum constant disturbance rate intended to represent disturbances other than fire (e.g. windthrow, Reick et al., 2013, and insect outbreaks, among others, e.g. 
Table 5. PFT-specific model parameters.

\begin{tabular}{|c|c|c|c|c|c|c|}
\hline & & Broadleaf tree & Needleleaf tree & $\mathrm{C} 3$ grass & $\mathrm{C} 4$ grass & Shrub \\
\hline$d_{\mathrm{r}, 1}$ & $\begin{array}{l}\text { root distribution parameter (Oleson } \\
\text { et al., 2013) }\end{array}$ & 6.5 & 7.0 & 11.0 & 11.0 & 7.0 \\
\hline$d_{\mathrm{r}, 2}$ & $\begin{array}{l}\text { root distribution parameter (Oleson } \\
\text { et al., 2013) }\end{array}$ & 1.5 & 2.0 & 2.0 & 2.0 & 1.5 \\
\hline$\alpha_{\text {snfree }}^{\text {can,vis,dir }}$ & $\begin{array}{l}\text { snow-free visible canopy albedo for di- } \\
\text { rect radiation (Houldcroft et al., 2009) }\end{array}$ & 0.02 & 0.01 & 0.04 & 0.03 & 0.04 \\
\hline$\alpha_{\text {snfree }}^{\text {can, vis, dif }}$ & $\begin{array}{l}\text { snow-free visible canopy albedo for dif- } \\
\text { fuse radiation (Houldcroft et al., 2009) }\end{array}$ & 0.03 & 0.01 & 0.05 & 0.04 & 0.04 \\
\hline$\alpha_{\text {snfree }}^{\text {can, nir,dir }}$ & $\begin{array}{l}\text { snow-free near-infrared canopy albedo } \\
\text { for direct radiation (Houldcroft et al., } \\
2009 \text { ) }\end{array}$ & 0.22 & 0.18 & 0.27 & 0.24 & 0.20 \\
\hline$\alpha_{\text {snfree }}^{\text {can, nir,dif }}$ & $\begin{array}{l}\text { snow-free near-infrared canopy albedo } \\
\text { for diffuse radiation (Houldcroft et al., } \\
2009 \text { ) }\end{array}$ & 0.26 & 0.19 & 0.31 & 0.28 & 0.21 \\
\hline$\alpha_{\mathrm{sn}}^{\mathrm{can}, \mathrm{vis}, \mathrm{dir} / \mathrm{dif}}$ & $\begin{array}{l}\text { snow-free visible canopy albedo } \\
\text { (Moody et al., 2007) }\end{array}$ & 0.44 & 0.31 & 0.70 & 0.70 & 0.55 \\
\hline$\alpha_{\mathrm{sn}}^{\mathrm{can}, \mathrm{nir}, \mathrm{dir} / \mathrm{dif}}$ & $\begin{array}{l}\text { snow-free near-infrared canopy albedo } \\
\text { (Moody et al., 2007) }\end{array}$ & 0.33 & 0.24 & 0.48 & 0.48 & 0.37 \\
\hline$T_{\mathrm{cmon}}^{\min }\left({ }^{\circ} \mathrm{C}\right)$ & $\begin{array}{l}\text { minimum coldest month temperature } \\
\text { for establishment (Sitch et al., 2003) }\end{array}$ & -17.0 & - & - & 15.5 & - \\
\hline$T_{\mathrm{cmon}}^{\max }\left({ }^{\circ} \mathrm{C}\right)$ & $\begin{array}{l}\text { maximum coldest month temperature } \\
\text { for establishment (Sitch et al., 2003) }\end{array}$ & - & -5.0 & 15.5 & - & - \\
\hline $\operatorname{gdd}_{\min }\left({ }^{\circ} C\right)$ & $\begin{array}{l}\text { minimum gdd for establishment (Sitch } \\
\text { et al., 2003) }\end{array}$ & 1200 & 350 & 0 & 0 & 0 \\
\hline$T_{\mathrm{cmon}}^{\mathrm{phen}}\left({ }^{\circ} C\right)$ & $\begin{array}{l}\text { coldest month temperature for phenol- } \\
\text { ogy }\end{array}$ & 5.0 & - & 0.0 & 0.0 & - \\
\hline$T_{\text {base }}^{\mathrm{gdd}}\left({ }^{\circ} C\right)$ & $\begin{array}{l}\text { base temperature for gdd (Sitch et al., } \\
\text { 2003) }\end{array}$ & 5.0 & 2.0 & 2.0 & 5.0 & 2.0 \\
\hline $\operatorname{gdd}_{\text {crit }}\left({ }^{\circ} C\right)$ & $\begin{array}{l}\text { gdd for full phenology (Sitch et al., } \\
\text { 2003) }\end{array}$ & 300 & - & 100 & 100 & - \\
\hline$g_{\min }\left(\mathrm{mm} \mathrm{s}^{-1}\right)$ & $\begin{array}{l}\text { minimum canopy conductance (Sitch } \\
\text { et al., 2003) }\end{array}$ & 0.5 & 0.3 & 0.5 & 0.5 & 0.5 \\
\hline$g_{1}$ & $\begin{array}{l}\text { parameter in optimal stomatal conduc- } \\
\text { tance formulation (Lin et al., 2015) }\end{array}$ & 4.0 & 2.3 & 3 & 1.6 & 4.0 \\
\hline$L_{\mathrm{ai}}^{\mathrm{min}}\left(\mathrm{m}^{2} \mathrm{~m}^{-2}\right)$ & $\begin{array}{l}\text { minimum leaf area index modified from } \\
\text { Clark et al. (2011) }\end{array}$ & 1 & 1 & 1 & 1 & 1 \\
\hline$L_{\mathrm{ai}}^{\max }\left(\mathrm{m}^{2} \mathrm{~m}^{-2}\right)$ & $\begin{array}{l}\text { maximum leaf area index modified } \\
\text { from Clark et al. (2011) }\end{array}$ & 8 & 6 & 3 & 3 & 3 \\
\hline $\operatorname{SLA}\left(\mathrm{m}^{-2} \mathrm{kgC}^{-1}\right)$ & specific leaf area (Kattge et al., 2011) & 20 & 10 & 40 & 40 & 17 \\
\hline$\gamma_{1}\left(\mathrm{yr}^{-1}\right)$ & leaf turnover rate (Kattge et al., 2011) & 0.5 & 0.3 & 1.0 & 1.0 & 0.5 \\
\hline$\gamma_{\mathrm{r}}\left(\mathrm{yr}^{-1}\right)$ & root turnover rate & 0.5 & 0.3 & 0.5 & 0.5 & 0.5 \\
\hline$\gamma_{\mathrm{s}}\left(\mathrm{yr}^{-1}\right)$ & $\begin{array}{l}\text { stem turnover rate modified from Clark } \\
\text { et al. (2011) }\end{array}$ & 0.005 & 0.005 & 0.2 & 0.2 & 0.05 \\
\hline$a_{\mathrm{wl}}\left(\mathrm{kgCm}^{-2}\right)$ & allometric coefficient & 2.0 & 2.0 & 0.01 & 0.01 & 0.5 \\
\hline$a_{\mathrm{wh}}$ & allometric coefficient for plant height & 3.5 & 6 & 0.15 & 0.17 & 1 \\
\hline
\end{tabular}

Dale et al., 2001) (Table 6). $\tau_{\text {fire }}$ is a characteristic fire return timescale, $\theta_{\text {crit }}$ is the critical soil moisture below which fires can occur and $C_{\mathrm{v} \text {, low }}$ and $C_{\mathrm{v} \text {, high }}$ are values of aboveground biomass $\left(C_{\mathrm{v}, \text { ag }}\right)$ that define the fuel availability limitation function. All parameter values are listed in Table 6.
Vegetation height is assumed to vary linearly with the balanced leaf area index:

$h_{\mathrm{v}}=a_{\mathrm{wh}} L_{\mathrm{ai}, \mathrm{b}}$.

$a_{\mathrm{wh}}$ is a PFT-specific factor that relates vegetation height with the balanced leaf area index (Table 5). $a_{\mathrm{wh}}$ values are selected 
Table 6. Dynamic vegetation model parameters.

\begin{tabular}{ll}
\hline$\nu_{\text {seed }}=0.001$ & vegetation seed fraction \\
$\gamma_{v, \text { min }}=0.002 \mathrm{yr}^{-1}$ & minimum vegetation disturbance rate \\
$\tau_{\text {fire }}=10 \mathrm{yr}$ & fire return timescale \\
$\theta_{\text {crit }}=0.15 \mathrm{~m}^{3} \mathrm{~m}^{-3}$ & critical soil moisture for fire disturbance \\
$C_{\mathrm{v}, \text { low }}=0.2 \mathrm{kgC} \mathrm{m}^{-2}$ & $\begin{array}{l}\text { minimum aboveground vegetation carbon } \\
\text { for fire disturbance } \\
\text { maximum aboveground vegetation carbon } \\
C_{\mathrm{v}, \text { high }}=1.0 \mathrm{kgCm}^{-2}\end{array}$ \\
& for fire disturbance \\
\hline
\end{tabular}

to give plant heights in accordance with data in Kattge et al. (2011). The stem area index, $S_{\mathrm{ai}}$, is taken to be $1 / 10$ of $L_{\mathrm{ai}, \mathrm{b}}$. The dynamic vegetation model has a monthly time step.

\subsubsection{Phenology}

The phenology of the PFTs is controlled by the coldest month temperature following Sitch et al. (2003). If the coldest month temperature falls below a PFT-specific value $T_{\mathrm{cmon}}^{\text {phen }}$ (Table 5), then the PFT in the grid cell is assumed to be deciduous and $L_{\mathrm{ai}}$ is computed from

$L_{\mathrm{ai}}=\phi L_{\mathrm{ai}, \mathrm{b}}$.

$\phi$ increases linearly with the growing degree days (gdd) above a PFT-specific base temperature $T_{\text {base }}^{\text {gdd }}$, at a PFTspecific rate determined by $\operatorname{gdd}_{\text {crit }}$ :

$\phi=\frac{\operatorname{gdd}}{\operatorname{gdd}_{\text {crit }}}$.

After $\phi$ reaches its maximum value of 1 , it remains constant until the air temperature drops below $T_{\text {base }}^{\text {gdd }}$. Then leaf senescence starts when the temperature drops below $T_{\text {base }}^{\text {gdd }}$ and continues until all leaves are lost to litter at $5{ }^{\circ} \mathrm{C}$ below $T_{\text {base }}^{\text {gdd }}$. Raingreen phenology is not represented in the model. Needleleaf trees are assumed to always be evergreen, independently of the climatic conditions. Given the relatively low specific leaf area of needleleaf trees (Table 5), they would not be competitive in very cold regions if they were deciduous. In reality, deciduous needleleaf trees have a much higher specific leaf area (Kattge et al., 2011), which allows them to be competitive. However, since evergreen and deciduous needleleaf trees are represented by a single PFT in the model, the different traits of evergreen and deciduous trees cannot be distinguished.

\subsubsection{Root distribution}

The vertical distribution of roots in the soil plays an important role in land surface models. It determines the water that is accessible by the plants and hence controls the exchange of water between the surface and the atmosphere. Water availability affects also plant productivity and consequently plays an important role in the competition between plant functional types. It also controls the vertical distribution of root litter input to the soil which is an important factor determining vertical soil carbon distribution. In PALADYN, we adopt the root distribution scheme proposed by Zeng (2001). The root fraction in each soil layer $\left(r_{l}\right)$ is derived from the cumulative root fraction:

$r(z)=1-0.5\left(e^{-d_{\mathrm{r}, 1} z}+e^{-d_{\mathrm{r}, 2} z}\right)$.

$d_{\mathrm{r}, 1}$ and $d_{\mathrm{r}, 2}$ are PFT-specific parameters (Table 5).

\subsection{Soil carbon}

Traditionally, in terrestrial biosphere models, soil carbon has been represented in terms of vertically integrated pools. Only recently vertically discretized soil carbon has started to be included in these models (e.g. Koven et al., 2009; Schaphoff et al., 2013). Vertically integrated models are unable to represent soil carbon dynamics in permafrost areas, where only part of the carbon stored in the soil column is affected by the seasonal thawing of the upper soil. Large quantities of carbon are stored in the permanently frozen soils around the Arctic (Tarnocai et al., 2009; Hugelius et al., 2014; Schuur et al., 2015) and to model the dynamics of this carbon stock it is necessary to include carbon separately in different soil layers. A proper representation of the permafrost carbon pool is important especially for carbon cycle modelling over long timescales.

Therefore, PALADYN has carbon distributed over the different soil layers where temperature and soil water are also computed. Additionally, each grid cell distinguishes between soil carbon in four different soil columns: mineral soil carbon and peat carbon below the vegetated surface tile, buried carbon below ice sheets and shelf carbon below the water on the ocean shelf (Fig. 1c). Each layer generally contains three carbon pools with different decomposability (Fig. 3). For unfrozen mineral soil carbon, the three pools are organized into litter, fast and slow carbon following Sitch et al. (2003). This structure is modified for peatlands, perennially frozen soils and buried carbon.

The generic prognostic equations for litter, fast and slow soil carbon pools are written as

$$
\begin{aligned}
\frac{\partial C_{\text {lit }}(z)}{\partial t} & =\Lambda(z)-k_{\text {lit }}(z) C_{\text {lit }}(z)+\frac{\partial}{\partial z}\left(D(z) \frac{\partial C_{\text {lit }}}{\partial z}\right) \\
& +\frac{\partial}{\partial z}\left(A(z) C_{\text {lit }}\right) \\
\frac{\partial C_{\text {fast }}(z)}{\partial t} & =\left(1-f_{\text {lit }}^{\text {resp }}\right) f_{\text {lit } \rightarrow \text { fast }} k_{\text {lit }}(z) C_{\text {lit }}(z) \\
& -k_{\text {fast }}(z) C_{\text {fast }}(z)+\frac{\partial}{\partial z}\left(D(z) \frac{\partial C_{\text {fast }}}{\partial z}\right) \\
& +\frac{\partial}{\partial z}\left(A(z) C_{\text {fast }}\right)
\end{aligned}
$$




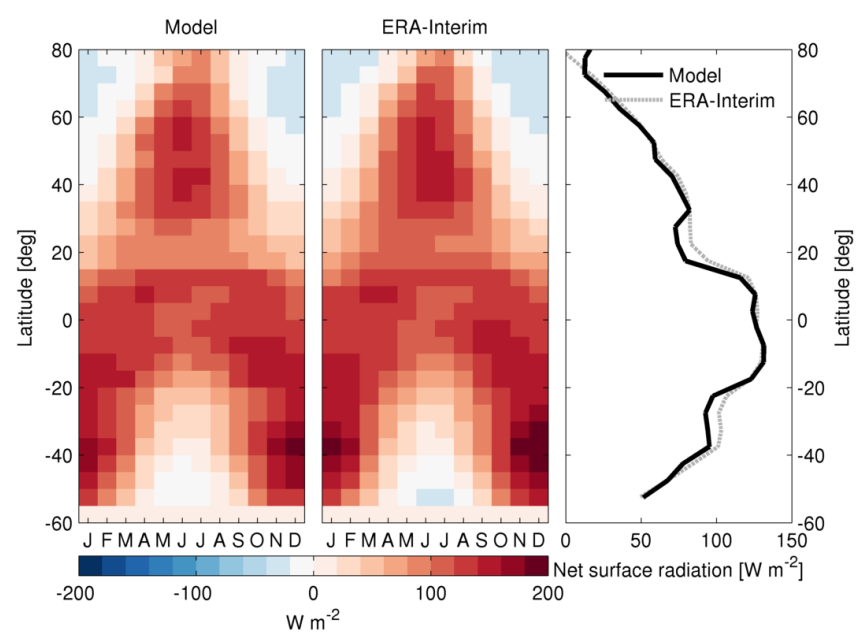

Figure 4. Seasonal variation of zonal mean net radiation at the surface modelled by PALADYN (left) and from ERA-Interim reanalysis (Dee et al., 2011) (middle). Right: modelled zonal annual mean net surface radiation compared to ERA-Interim reanalysis (Dee et al., 2011).

$$
\begin{aligned}
\frac{\partial C_{\text {slow }}(z)}{\partial t} & =\left(1-f_{\text {lit }}^{\text {resp }}\right) f_{\text {lit } \rightarrow \text { slow }} k_{\text {lit }}(z) C_{\text {lit }}(z) \\
& -k_{\text {slow }}(z) C_{\text {slow }}(z)+\frac{\partial}{\partial z}\left(D(z) \frac{\partial C_{\text {slow }}}{\partial z}\right) \\
& +\frac{\partial}{\partial z}\left(A(z) C_{\text {slow }}\right) .
\end{aligned}
$$

Litter carbon is increased by litterfall $\Lambda(z)$. A fraction $f_{\text {lit }}^{\text {resp }}$ of the decomposed litter carbon goes directly into the atmosphere, while the rest goes partly into the fast carbon pool $\left(f_{\text {lit } \rightarrow \text { fast }}\right)$ and partly into the slow carbon pool $\left(f_{\text {lit } \rightarrow \text { slow }}\right)$ (Table 7). Each carbon pool decomposes at a specific rate $k$, which depends on soil temperature and soil moisture. The vertical redistribution of soil carbon between soil layers is represented as an advective-diffusive process with diffusivity $D(z)$ and advection velocity $A(z)$.

Over the vegetated grid cell part, the local litter, the litter originating from competition between the PFTs and the litter from large-scale disturbances are aggregated to give an average litterfall $\left(\Lambda_{\mathrm{veg}}(z)\right)$ as in Cox (2001). Litter from the roots is added to the different soil layers depending on the root fraction in each layer, while litter from leaves and stem is added to the top soil layer.

When ice sheets are expanding into vegetated areas, a fraction $f_{\mathrm{veg} \rightarrow \text { bur }}$ of the vegetation carbon is assumed to be directly buried below the ice and the remaining is added to the litter pools of the vegetated part:

$$
\begin{aligned}
& \Lambda_{\text {bur }}(z)=f_{\text {veg } \rightarrow \text { bur }} \overline{C_{\mathrm{v}}}(z) \Delta f_{\text {ice }} \\
& \Lambda_{\text {veg }}(z)=\left(1-f_{\text {veg } \rightarrow \text { bur }}\right) \overline{C_{\mathrm{v}}}(z) \Delta f_{\text {ice }} .
\end{aligned}
$$

$\overline{C_{\mathrm{v}}}(z)$ is the mean vegetation carbon content of the vegetated grid cell part in the different soil layers. For the purpose of litter computation the aboveground vegetation carbon is considered to be part of the top soil layer. $\Delta f_{\text {ice }}$ is the increase of ice sheet fraction in the grid cell.

When sea level is rising and shelf areas become flooded, the flooded vegetation is assumed to die instantaneously and vegetation carbon is added directly to the shelf litter pool:

$\Lambda_{\text {shelf }}(z)=\overline{C_{\mathrm{v}}}(z) \Delta f_{\text {shelf }}$,

where $\Delta f_{\text {shelf }}$ is the increase in shelf fraction.

Vertical carbon diffusivity in unfrozen mineral soils is assumed to be determined by bioturbation and $D(z)=D_{\text {bio }}$ following Braakhekke et al. (2011) (Table 7). In permafrost areas, the diffusivity represents cryoturbation in the active layer. $D(z)$ is set to a constant value in the active layer and is assumed to linearly decrease below it to a value of zero at a multiple $\left(n_{\mathrm{al}}\right)$ of the active layer thickness $z_{\mathrm{al}}$ (Koven et al., 2009):

$D(z)= \begin{cases}D_{\text {cryo }} & z \leq z_{\mathrm{al}} \\ D_{\text {cryo }}\left(1-\frac{z-z_{\mathrm{al}}}{\left(n_{\mathrm{al}}-1\right) z_{\mathrm{al}}}\right) & z_{\mathrm{al}}<z \leq n_{\mathrm{al}} z_{\mathrm{al}} .\end{cases}$

The value of $D_{\text {cryo }}$ is given in Table 7 .

To represent the effects of sedimentation on vertical carbon movement in the soil an advection term is also included in Eqs. (85), (86) and (87), similar to what has been introduced by Koven et al. (2013) and Zhu et al. (2016). The advection velocity $(A)$ is set to zero for now.

The decomposition rates for mineral soil carbon depend on temperature, liquid water content in the soil layers and the inundated fraction of the grid cell:

$$
\begin{aligned}
k_{\mathrm{x}}^{\min }(z) & =\left(1-f_{\text {inun }}\right) k_{\mathrm{x}, 10} f_{\mathrm{T}}(z) f_{\theta}(z) \\
& +f_{\text {inun }} k_{\mathrm{x}, 10} f_{\mathrm{T}}(z) f_{\theta, \text { sat }}(z),
\end{aligned}
$$

for $x=$ lit, fast, slow. The inundated grid cell fraction is the wetland fraction with the peatland fraction removed, $f_{\text {inun }}=$ $f_{\text {wet }}-f_{\text {peat }} . k_{\text {lit, } 10}, k_{\text {fast }, 10}$ and $k_{\text {slow, } 10}$ are the litter, fast and slow carbon decomposition rates at $10^{\circ} \mathrm{C}$ and field capacity and are given in Table 7 . The temperature dependence follows a modified Arrhenius equation (Lloyd and Taylor, 1994):

$$
\begin{aligned}
& f_{\mathrm{T}}(z)= \\
& \quad \exp \left[308.56\left(\frac{1}{56.02}-\frac{1}{46.02+T_{\mathrm{S}}(z)-T_{0}}\right)\right] .
\end{aligned}
$$

The soil moisture dependence is taken from Porporato et al. (2003) and gives a linear increase of the decomposition rate up to field capacity and a hyperbolic decrease above field capacity:

$f_{\theta}(z)= \begin{cases}\frac{\theta_{\mathrm{w}}(z)}{\theta_{\mathrm{cc}}} & \theta_{\mathrm{w}}(z) \leq \theta_{\mathrm{fc}} \\ \frac{\theta_{\mathrm{fc}}}{\theta_{\mathrm{w}}(z)} & \theta_{\mathrm{w}}(z)>\theta_{\mathrm{fc}} .\end{cases}$

The soil moisture dependence factor for inundated land, $f_{\theta \text {, sat }}$, is simply the value of $f_{\theta}$ at saturation. 
Table 7. Soil carbon model parameters.

\begin{tabular}{|c|c|}
\hline$f_{\text {lit }}^{\text {resp }}=0.7$ & fraction of decomposed litter carbon going to atmosphere (Sitch et al., 2003) \\
\hline$f_{\text {lit } \rightarrow \text { fast }}=0.985$ & fraction of decomposed litter transferred to fast carbon pool (Sitch et al., 2003) \\
\hline$f_{\text {lit } \rightarrow \text { slow }}=0.015$ & caction of decomposed litter transferred to slow carbon pool (Sitch et al., 2003) \\
\hline$D_{\text {bio }}=1 \times 10^{-4} \mathrm{~m}^{2}$ year $^{-1}$ & bioturbation rate (Braakhekke et al., 2011) \\
\hline$D_{\text {cryo }}=5 \times 10^{-4} \mathrm{~m}^{2}$ year $^{-1}$ & cryoturbation rate (Koven et al., 2009, 2013) \\
\hline$k_{\text {lit, } 10}=2.86 \mathrm{yr}^{-1}$ & litter carbon turnover rate at $10^{\circ} \mathrm{C}$ (Sitch et al., 2003) \\
\hline$k_{\text {fast }, 10}=33.3 \mathrm{yr}^{-1}$ & fast soil carbon turnover rate at $10^{\circ} \mathrm{C}$ (Sitch et al., 2003) \\
\hline$k_{\text {slow }, 10}=1000 \mathrm{yr}^{-1}$ & slow soil carbon turnover rate at $10^{\circ} \mathrm{C}$ (Sitch et al., 2003) \\
\hline$k_{\mathrm{acro}, 10}=30 \mathrm{yr}^{-1}$ & acrotelm carbon turnover rate at $10^{\circ} \mathrm{C}$ \\
\hline$k_{\text {cato }, 10}=1000 \mathrm{yr}^{-1}$ & catotelm carbon turnover rate at $10^{\circ} \mathrm{C}($ Spahni et al., 2013) \\
\hline$k_{\mathrm{acro} \rightarrow \text { cato }}=15 \times 10^{-3} \mathrm{yr}^{-1}$ & catotelm formation rate (Wania et al., 2009; Kleinen et al., 2012) \\
\hline$f_{\theta, \text { peat }}=0.3$ & soil moisture factor for peat carbon decomposition rate at saturation (Wania et al., 2009) \\
\hline$\rho_{\text {acro }}=20 \mathrm{kgCm}^{-3}$ & acrotelm carbon density (Clymo, 1984; Clymo et al., 1998) \\
\hline$\rho_{\text {cato }}=50 \mathrm{kgC} \mathrm{m}^{-3}$ & catotelm carbon density (Turunen et al., 2002; Malmer and Wallén, 2004) \\
\hline$C_{\text {acro, crit }}=5 \mathrm{kgCm}^{-2}$ & minimum acrotelm carbon content for catotelm formation (Wania et al., 2009) \\
\hline$C_{\text {peat }}^{\text {crit }}=50 \mathrm{kgC} \mathrm{m}^{-2}$ & minimum peat carbon content for peat survival (Stocker et al., 2014) \\
\hline$f_{\text {peat }}^{\min }=0.001$ & minimum peatland fraction \\
\hline $\begin{array}{l}\left.\frac{\mathrm{d} C_{\text {peat }}}{\mathrm{d} t}\right|_{\text {crit }}=10^{-3} \mathrm{kgC} \mathrm{m}^{-2} \mathrm{yr}^{-1} \\
f_{\mathrm{CH}_{4}: \mathrm{C}}^{\mathrm{Wet}}=0.07\end{array}$ & $\begin{array}{l}\text { minimum peat carbon uptake for peat survival (Stocker et al., 2014) } \\
\text { fraction of carbon respired as methane from wetlands (Spahni et al., 2011; Riley et al., 2011) }\end{array}$ \\
\hline$f_{\mathrm{CH}_{4}: \mathrm{C}}^{\text {peat }}=0.2$ & fraction of carbon respired as methane from peatlands (Spahni et al., 2011) \\
\hline
\end{tabular}

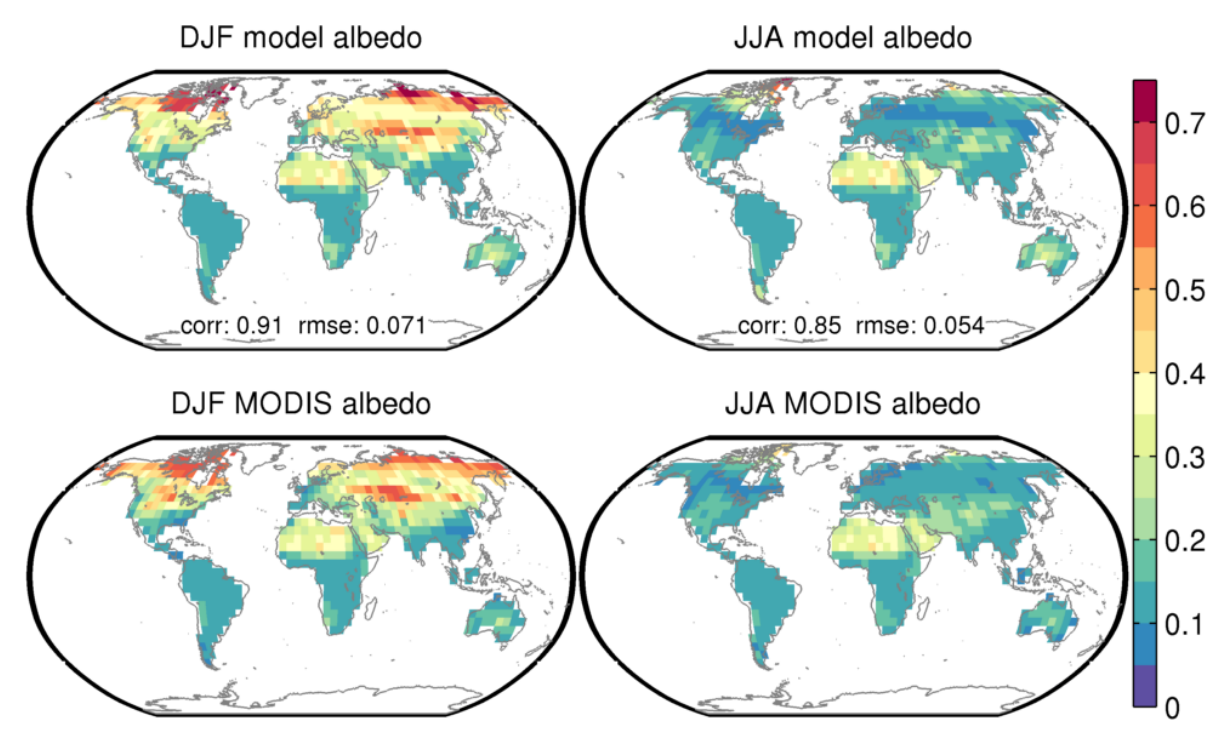

Figure 5. December-January-February (left) and June-July-August (right) surface albedo as modelled by PALADYN (top) and derived from MODIS data (Schaaf and Wang, 2015) (bottom). The displayed surface albedo is a weighted mean of visible and near-infrared broadband albedo for diffuse radiation. Spatial correlation between model and data (corr) and root mean square error (RMSE) are indicated in the top panels. 
PALADYN allows for the possibility to effectively treat the carbon in frozen soils as inert. If inert permafrost carbon is switched on, the decomposition rates in Eq. (92) are additionally weighted by a frozen soil factor, $f_{\text {inert }}$ :

$k_{\mathrm{x}}^{\min }(z)=\left(1-f_{\text {inert }}(z)\right) k_{\mathrm{x}}^{\min }(z)+f_{\text {inert }}(z) k_{\text {inert }}$,

for $x=$ lit, fast, slow. All carbon is assumed to be inert if the fraction of frozen water in a layer exceeds $f_{\text {frz,crit }}$ :

$f_{\text {inert }}(z)=\min \left(1, \frac{1}{f_{\text {frz, crit }}} \frac{\theta_{\mathrm{i}}}{\theta_{\mathrm{i}}+\theta_{\mathrm{w}}}\right)$.

Therefore, in soil layers where at least a fraction $f_{\text {frz,crit }}$ of water is frozen all year round, carbon is effectively decomposing at the very low rate $k_{\text {inert }}$.

More details on the parameterization of carbon dynamics below ice sheets and on the ocean shelf and of permafrost carbon will be given in a future paper dedicated to processes active on glacial-interglacial cycle timescales.

\subsubsection{Peatlands}

Peat carbon is treated slightly differently from the other carbon pools. We follow the approach of Kleinen et al. (2012) and distinguish between a surface litter layer and an acrotelm layer where carbon is decomposed partly under oxic and partly under anoxic conditions, depending on the position of the water table. Both litter and acrotelm are assumed to be contained in the top soil layer. In the layers below the catotelm, decomposition occurs without oxygen all year round. The prognostic equations for peat litter, acrotelm and catotelm carbon are

$$
\begin{aligned}
& \frac{\partial C_{\text {lit }}^{\text {peat }}}{\partial t}=\Lambda_{\text {peat }}-k_{\text {lit }}^{\text {peat }} C_{\text {lit }}^{\text {peat }} \\
& \begin{aligned}
& \frac{\partial C_{\text {acro }}}{\partial t}=\left(1-f_{\text {lit }}^{\text {resp }}\right) k_{\text {lit }}^{\text {peat }} C_{\text {lit }}^{\text {peat }}-k_{\text {acro } \rightarrow \text { cato }} C_{\text {acro }} \\
&-k_{\text {acro }} C_{\text {acro }} \\
& \frac{\partial C_{\text {cato }}(z)}{\partial t}=k_{\text {acro } \rightarrow \text { cato }} C_{\text {acro }}-k_{\text {cato }}(z) C_{\text {cato }}(z) .
\end{aligned}
\end{aligned}
$$

The transfer from acrotelm to catotelm carbon occurs only once a critical acrotelm carbon content $C_{\text {acro,crit }}=5 \mathrm{kgC} \mathrm{m}^{-2}$ is reached, as suggested by Wania et al. (2009). Typical acrotelm carbon densities are around $20 \mathrm{kgCm}^{-3}$, so this threshold roughly corresponds to assuming that transfer to the catotelm starts when the acrotelm reaches a thickness of $25 \mathrm{~cm}$, which is a typical value of observed acrotelm thickness. When this threshold is exceeded, acrotelm carbon is transferred to the catotelm in the second soil layer. Peat is assumed to grow thicker by accumulating carbon on top and therefore in the model the catotelm is shifted to lower soil layers once the catotelm carbon density $\rho_{\text {cato }}$ has been exceeded in a given layer. For the same reason, the vertical diffusivity of peat carbon is set to 0 . Litterfall over peatlands is assumed to be the same as over mineral soil, but to be added to the top soil layer only: $\Lambda_{\text {peat }}=\sum_{z} \Lambda_{\text {veg }}(z)$. The decomposition rates for litter, acrotelm and catotelm are given by

$k_{\text {lit }}^{\text {peat }}=k_{\text {lit }, 10} f_{\mathrm{T}}(1)\left(f_{\text {oxic }}+\left(1-f_{\text {oxic }}\right) f_{\theta, \text { peat }}\right)$

$k_{\text {acro }}=k_{\text {acro, } 10} f_{\mathrm{T}}(1)\left(f_{\text {oxic }}+\left(1-f_{\text {oxic }}\right) f_{\theta \text {,peat }}\right)$

$k_{\text {cato }}(z)=k_{\text {cato, } 10} f_{\mathrm{T}}(z) f_{\theta \text {, peat }}$.

Since peatland soil temperature is not separately computed by the model, the temperature factor is calculated using the grid cell mean temperature. $f_{\theta \text {,peat }}$ is taken to be equal to 0.3 as in Wania et al. (2009) and Koven et al. (2013). The values of the reference decomposition rates are given in Table 7 . The fraction of litter and acrotelm that is respiring in oxic conditions, $f_{\text {oxic }}$, is determined from the mean grid cell water table depth $z_{\nabla}$ and the minimum monthly water table position $z_{\nabla}^{\min }$ assuming that the seasonal water table variations in the peatland fraction follow the grid cell mean water table and that the amplitude of water table variations in peatland is reduced compared to the grid cell mean and limited to the acrotelm thickness:

$f_{\text {oxic }}=\frac{\min \left(z_{\text {acro }}, \max \left(0, z_{\nabla}-z_{\nabla}^{\min }\right)\right)}{z_{\text {acro }}}$.

Peatland expansion and contraction is modelled partly following Stocker et al. (2014). The grid cell fraction that is wetland for at least 3 months of the year is considered to be potential peatland area $f_{\text {peat }}^{\text {pot }}$. The actual peatland area $f_{\text {peat }}$ is simulated as

$$
f_{\text {peat }, n+1}=\left\{\begin{array}{l}
\min \left((1+r) f_{\text {peat }, n}, f_{\text {peat }}^{\text {pot }}\right) \\
\text { if } \frac{\mathrm{d} C_{\text {peat }}}{\mathrm{d} t} \geq\left.\frac{\mathrm{d} C_{\text {peat }}}{\mathrm{d} t}\right|_{\text {crit }} \text { or } C_{\text {peat }} \geq C_{\text {peat }}^{\text {crit }}, \\
\max \left((1-r) f_{\text {peat }, n} f_{\text {peat }}^{\text {min }}\right) \\
\text { if } \frac{\mathrm{d} C_{\text {peat }}}{\mathrm{d} t}<\left.\frac{\mathrm{d} C_{\text {peat }}}{\mathrm{d} t}\right|_{\text {crit }} \text { and } C_{\text {peat }}<C_{\text {peat }}^{\text {crit }} .
\end{array}\right.
$$

Peat is expanding if the annual mean rate of carbon uptake $\left(\mathrm{d} C_{\text {peat }} / \mathrm{d} t\right)$ is greater than a critical value $\mathrm{d} C_{\text {peat }} /\left.\mathrm{d} t\right|_{\text {crit }}$ or if peat carbon exceeds a value $C_{\text {peat }}^{\text {crit }}$; otherwise peatland area is shrinking. To account for inertia in lateral peatland expansion and contraction, the relative areal change rate is limited to $1 \% \mathrm{yr}^{-1}\left(r=0.01 \mathrm{yr}^{-1}\right)$. When the peat area is changing, carbon is simply redistributed between mineral soil and peat carbon pools, layer by layer, with the following rules: $C_{\text {lit }}^{\text {peat }} \leftrightarrow C_{\text {lit }}, C_{\text {acro }} \leftrightarrow C_{\text {fast }}$ and $C_{\text {cato }} \leftrightarrow C_{\text {slow }}$. A minimum peatland extent in every grid cell $\left(f_{\text {peat }}^{\text {min }}\right)$ insures that peatlands are always "seeded".

\subsection{Methane emissions}

Methane emissions are simulated as a constant fraction of heterotrophic respiration when respiration occurs under anaerobic conditions, as is the case in wetlands, peatlands and flooded ocean shelves. The fraction of carbon that is respired as methane, $f_{\mathrm{CH}_{4}: \mathrm{C}}$, is different for wetlands, peatlands and ocean shelves (Table 7). 


\subsection{Carbon isotopes: ${ }^{13} \mathrm{C}$ and ${ }^{14} \mathrm{C}$}

The stable carbon isotope ${ }^{13} \mathrm{C}$ and radiocarbon ${ }^{14} \mathrm{C}$ are tracked in PALADYN trough all carbon pools in vegetation and soil. Discrimination is simulated only during photosynthesis and follows the model outlined in Lloyd and Farquhar (1994). The discrimination factor $\Delta$ for $\mathrm{C} 3$ and C4 photosynthesis is given by

$\Delta= \begin{cases}4.4 \frac{c_{\mathrm{a}}-c_{\mathrm{i}}}{c_{\mathrm{a}}}+27 \frac{c_{\mathrm{i}}}{c_{\mathrm{a}}} & \mathrm{C} 3 \\ 4.4 \frac{c_{\mathrm{a}}-c_{\mathrm{i}}}{c_{\mathrm{a}}}+(-5.7+20 \cdot 0.35) \frac{c_{\mathrm{i}}}{c_{\mathrm{a}}} & \mathrm{C} 4 .\end{cases}$

Radiocarbon decay is ignored in the vegetation carbon pools because of their fast turnover time relative to the ${ }^{14} \mathrm{C}$ decay rate. In all soil carbon pools, radiocarbon has a half life of 5730 years.

\section{Model spinup}

Some of the processes related to vegetation and soil carbon dynamics have very long intrinsic timescales, and therefore long simulations of at least 10000 years would be required to get the system into an equilibrium state with prescribed boundary conditions. Even though this is, in principle, feasible with PALADYN, it is in fact impractical for test and tuning purposes. Therefore, the possibility to run the vegetation and carbon cycle modules with an artificially high internal integration time step of 1000 or more years is implemented in PALADYN. This is possible due to the fully implicit formulation of the model components. In this equilibrium spinup mode, the vegetation and carbon cycle modules are called only at the end of each simulation year but using annually cumulated NPP and litterfall and annual mean decomposition rates for soil carbon. Using the equilibrium spinup mode brings the model close to equilibrium already after around 100 years of simulation. A period of 100 years is also the spinup time required to bring the physical state of the land model, particularly permafrost related processes, into equilibrium with climate. The equilibrium spinup mode can however not be applied to processes which are intrinsically out of equilibrium such as peatlands and inert permafrost carbon. To get the present state of these pools a transient simulation over at least one glacial cycle is required.

\section{Evaluation}

In this section, the performance of PALADYN for the present day is presented and discussed. The model is designed for large-scale applications, and therefore the model evaluation is done at a global scale, although in principle it would be possible to run the model in a single column mode forced with site-level observations. For the model evaluation, an offline transient simulation from 1901 to 2010 is performed. In offline mode, PALADYN needs several monthly climate

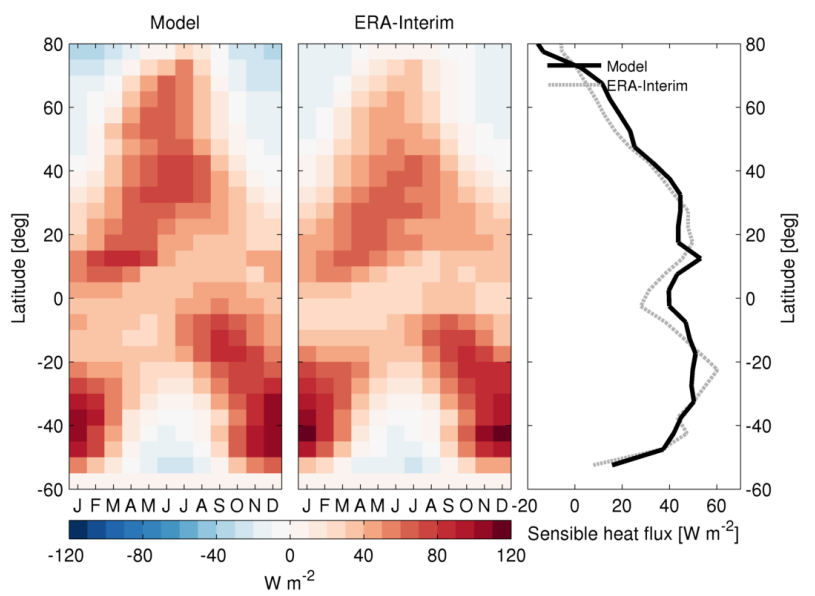

Figure 6. Seasonal variation of zonal mean sensible heat flux modelled by PALADYN (left) and from ERA-Interim reanalysis (Dee et al., 2011) (middle). Right: modelled zonal annual mean sensible heat flux compared to ERA-Interim reanalysis (Dee et al., 2011).

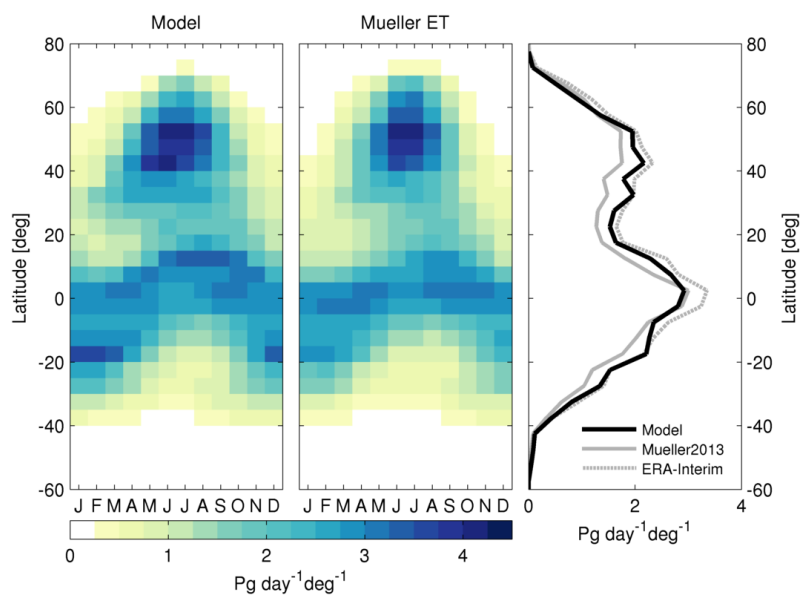

Figure 7. Seasonal variation of zonally integrated evapotranspiration modelled by PALADYN (left) and estimated by Mueller et al. (2013) (middle). Right: modelled zonal annual mean evapotranspiration compared to observation-based estimates from Mueller et al. (2013) and ERA-Interim reanalysis (Dee et al., 2011).

fields as input as listed in Table 9. In addition, the annual atmospheric $\mathrm{CO}_{2}$ concentration has to be provided. For the historical simulation of the past century the WATCH climate forcing (Weedon et al., 2011, 2014) based on ERA-40 (Uppala et al., 2005) and ERA-Interim reanalysis (Dee et al., 2011) combined with GPCC precipitation (Schneider et al., 2014) is used. $\mathrm{CO}_{2}$ is prescribed from Bereiter et al. (2015) combined with Mauna Loa data (Keeling et al., 1976).

Before running the transient experiment, the model is spun up for 30000 years with the mean 1901-1930 climate as forcing and the $1901 \mathrm{CO}_{2}$ concentration of $295 \mathrm{ppm}$. To get a rough estimate of peatland area and carbon, during the first 4000 years of this spinup phase, the peatland module 
Table 8. Global values of relevant model quantities over the time period 1981-2010 compared to observation-based estimates.

\begin{tabular}{|c|c|c|}
\hline & Model & Observation-based estimates \\
\hline Evapotranspiration $\left(\times 10^{15} \mathrm{~kg} \mathrm{yr}^{-1}\right)$ & 71 & 64-73 (Mueller et al., 2013; Trenberth et al., 2007) \\
\hline Runoff $\left(\times 10^{15} \mathrm{~kg} \mathrm{yr}^{-1}\right)$ & 37 & 38-40 (Fekete et al., 2002; Baumgartner and Reichel, 1975) \\
\hline Permafrost area $\left(\mathrm{mln} \mathrm{km}^{2}\right)$ & 16 & 13-18 (Gruber, 2012) \\
\hline $\mathrm{GPP}\left(\mathrm{PgC} \mathrm{yr}^{-1}\right)$ & 132 & $115-131$ (Beer et al., 2010) \\
\hline $\mathrm{NPP}\left(\mathrm{PgC} \mathrm{yr}^{-1}\right)$ & 70 & $42-70($ Ito, 2011) \\
\hline Vegetation carbon $(\mathrm{PgC})$ & 580 & 470-650 (Prentice et al., 2001) \\
\hline Top metre soil carbon $(\mathrm{PgC})$ & 1170 & 890-1660 (Todd-Brown et al., 2013) \\
\hline Soil carbon in permafrost area $(\mathrm{PgC})$ & 555 & 1100-1500 (Hugelius et al., 2014) \\
\hline Peat carbon $(\mathrm{PgC})$ & 510 & 530-694 (Yu et al., 2010) \\
\hline Maximum monthly wetland area $\left(\mathrm{mln} \mathrm{km}^{2}\right)$ & 5.1 & 5 (Prigent et al., 2007; Papa et al., 2010) \\
\hline Peatland area $\left(\mathrm{mln} \mathrm{km}{ }^{2}\right)$ & 3.8 & 4.4 (Yu et al., 2010) \\
\hline Total $\mathrm{CH}_{4}$ emissions $\left(\mathrm{TgCH}_{4} \mathrm{yr}^{-1}\right)$ & 160 & 115-215 (Bloom et al., 2010; Bousquet et al., 2006) \\
\hline Tropical $\mathrm{CH}_{4}$ emissions $\left(\mathrm{TgCH}_{4} \mathrm{yr}^{-1}\right.$ ) & 96 & 63-119 (Bloom et al., 2010; Bousquet et al., 2006) \\
\hline Extratropical $\mathrm{CH}_{4}$ emissions $\left(\mathrm{TgCH}_{4} \mathrm{yr}^{-1}\right)$ & 72 & 39-89 (Bloom et al., 2010; Bousquet et al., 2006) \\
\hline
\end{tabular}

Table 9. Climate forcing fields needed to run PALADYN in offline mode.

is enabled to allow peatlands to establish. For the rest of the spinup phase peat carbon is kept constant. Finally, the model is run in transient mode for the historical period forced with annually varying climate and $\mathrm{CO}_{2}$ concentrations. Peatland area is kept constant during this phase but peat carbon is interactive.

Depending on the time interval covered by the different observational data products, the model climatology over the given time period is computed and used to evaluate the different model components, as described next.

\subsection{Physical processes}

The modelled net radiation absorbed at the surface is in good agreement with reanalysis data both for the seasonal cycle and the annual mean (Fig. 4). With the downwelling shortwave and longwave radiation used as forcing, the net surface radiation is determined by the modelled surface emissivity and albedo. The surface albedo for winter and summer is well simulated in the model (Fig. 5).

A correct partitioning of the absorbed radiation between sensible, latent and ground heat flux is of fundamental importance for a land model. The modelled sensible heat flux com-

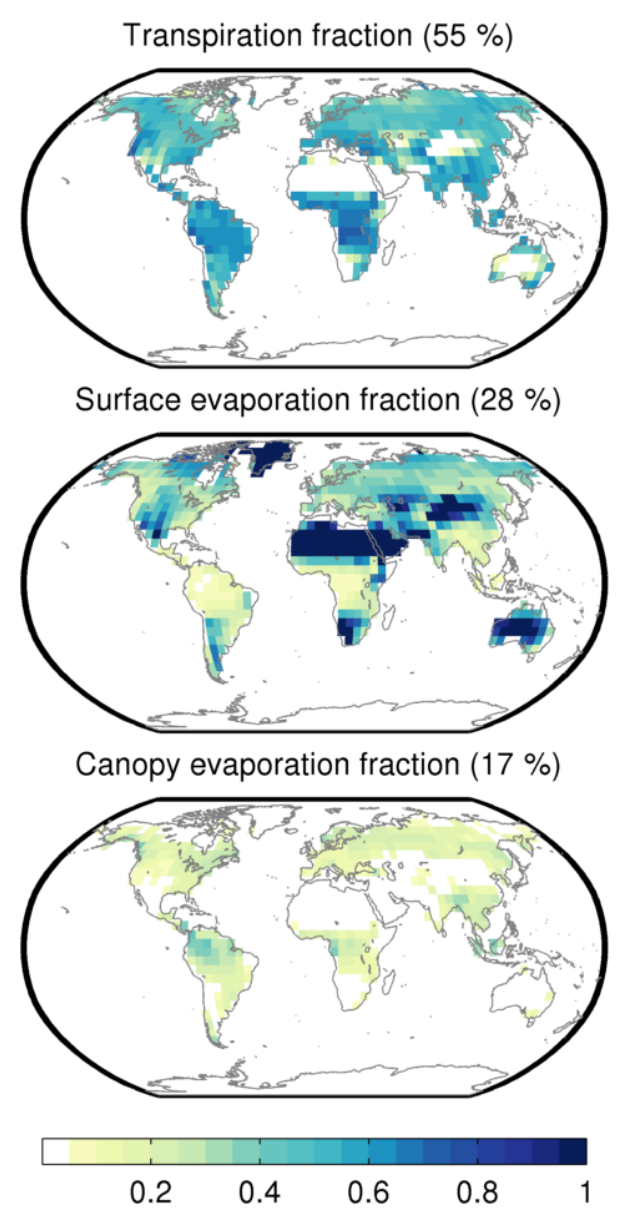

Figure 8. Partitioning of modelled total annual evapotranspiration between transpiration (top), surface evaporation (middle) and canopy evaporation (bottom). The global percentage of each component is shown above the corresponding plot. 


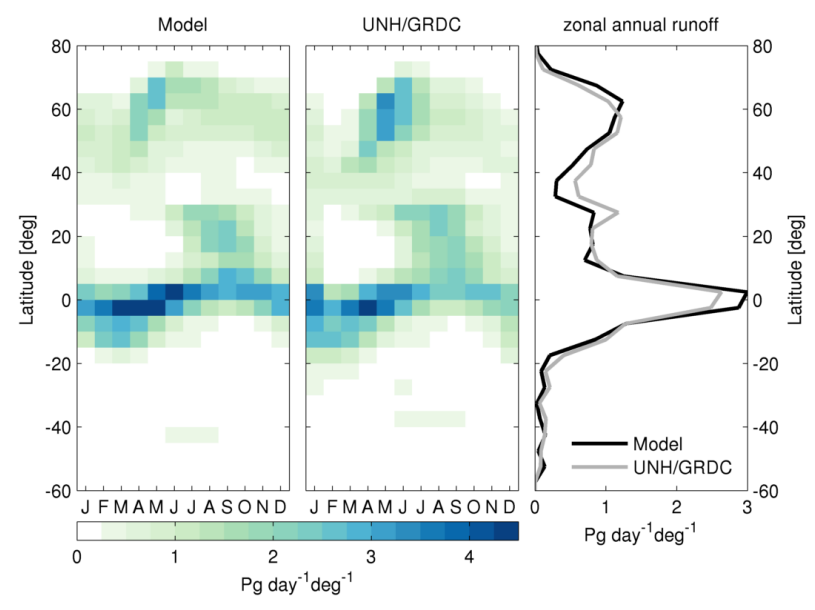

Figure 9. Seasonal variation of zonally integrated water runoff modelled by PALADYN (left) and observations from UNH/GRDC (Fekete et al., 2002) (middle). Right: modelled zonal annual mean runoff compared to observation-based estimates from Fekete et al. (2002). Modelled and observed runoff is averaged over the time period 1979-2010.

pares well with ERA-Interim reanalysis data except for the tropics, where it is systematically overestimated, and for the subtropics, where it is underestimated in the model (Fig. 6). Evapotranspiration, and therefore the latent heat flux, tends to be overestimated by the model everywhere except for the tropics when compared to estimates from Mueller et al. (2013) (Fig. 7). However, it is in good agreement with ERAInterim. This is to be expected because evapotranspiration strongly depends on surface air conditions which are used to force the model, which are based on ERA-Interim. The discrepancy between model and (model-based) estimates from Mueller et al. (2013) might therefore reflect a deficiency in the forcing rather than in the model. Modelled annual global land evapotranspiration is $71 \times 10^{15} \mathrm{~kg} \mathrm{yr}^{-1}$, in the range of observational estimates (Table 8 ).

Evapotranspiration is the sum of transpiration from vegetation, surface evaporation and canopy interception and reevaporation. The partitioning of total evapotranspiration between the different components is shown in Fig. 8. Transpiration is dominant in the tropics and generally in densely vegetated areas. A significant amount of precipitation is directly re-evaporated back to the atmosphere from plant canopies, particulary in the tropics and over the boreal forest. Surface evaporation is the only process acting in desert regions. Globally, transpiration, surface evaporation and canopy evaporation account for around 50,30 and 20\% of total evapotranspiration, respectively. This compares favourably with Dirmeyer et al. (2006), who estimated total global evapotranspiration to be partitioned in $48 \%$ from transpiration, $36 \%$ from soil evaporation and $16 \%$ from canopy interception and re-evaporation using an ensemble of land surface models.
As a consequence of the overestimation of evapotranspiration, simulated runoff is underestimated over Northern Hemisphere midlatitudes (Fig. 9). Compared to data from Fekete et al. (2002), the modelled NH runoff from melting snow in spring tends to be less concentrated to May and June and more gradually distributed over the whole summer season. Global annual runoff is $37 \times 10^{15} \mathrm{~kg} \mathrm{yr}^{-1}$ (Table 8).

Modelled December-January-February (DJF) and JuneJuly-August (JJA) soil moisture shows generally a good agreement with estimates from satellite data (Liu et al., 2012; Wagner et al., 2012) in the tropics, while the model tends to simulate a dryer top soil in high northern latitudes (Fig. 10). This is partly a consequence of using a globally uniform soil porosity. However, it has to be mentioned that the satellite data are representative for the soil moisture of the top few centimetres of soil, while the top model soil layer is $20 \mathrm{~cm}$ thick.

The mean annual simulated wetland area is $3 \mathrm{mln} \mathrm{km}^{2}$. Some features of the maximum monthly wetland extent are reasonably well captured by the model (Fig. 11). Compared to the multi-satellite product from GIEMS (Prigent et al., 2007; Papa et al., 2010) the model simulates larger wetland extent in tropical forest areas and northern peatland areas. However, if compared to other wetland products based on data other than from satellite, GIEMS is underestimating wetlands below dense forests (e.g. the Amazon forest) (Melack and Hess, 2010) and in peatland regions of northern Canada and eastern Siberia (Stocker et al., 2014). In southeast Asia, the GIEMS wetland extent also includes extensive rice cultivation areas, which are not represented in the model. The modelled seasonal variation in global wetland area is in very good agreement with GIEMS (Fig. 12).

The NH spring evolution of snow mass is compared to the GlobSnow dataset (Takala et al., 2011; Luojus et al., 2013) in Fig. 13. The spatial distribution of snow is well captured by the model. However, the model tends to melt snow slightly too late in spring, as highlighted also by the seasonal evolution of the total NH snow mass (Fig. 14). The overestimation of snow mass in spring is a feature common to many state-ofthe-art Earth system models (Shi and Wang, 2015). The interannual variability of spring snow over the $\mathrm{NH}$ is also largely in agreement with the GlobSnow data, suggesting that the model has a reasonably good sensitivity (Fig. 15).

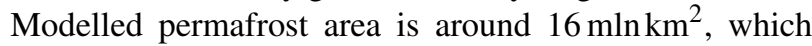
compares well with observations (Table 8). The permafrost extent over Siberia and northern Canada are generally well simulated by the model (Fig. 16). Also the active layer thickness over the Yakutia region is consistent with the data from Beer et al. (2013) (Fig. 16).

\subsection{Biogeochemistry}

The modelled annual mean gross primary productivity is compared to estimates from Jung et al. (2009), Beer et al. (2010) and Jung et al. (2011) in Fig. 17. Model and data are 


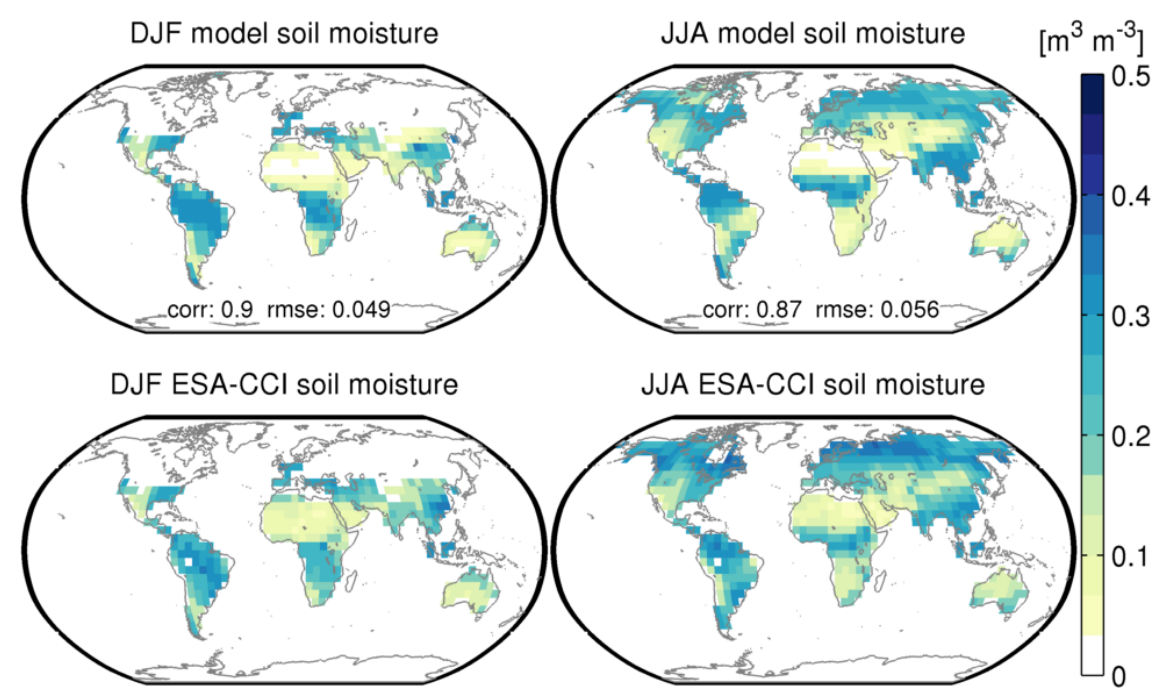

Figure 10. December-January-February (left) and June-July-August (right) soil moisture. The modelled soil moisture (top) is the volumetric soil moisture of the top soil layer (top $20 \mathrm{~cm}$ ). The observed soil moisture is from ESA-CCI (Liu et al., 2012; Wagner et al., 2012) and represents the moisture content of the top few centimetres of soil. Snow-covered regions are masked out. Spatial correlation between model and data (corr) and RMSE are indicated between the panels.

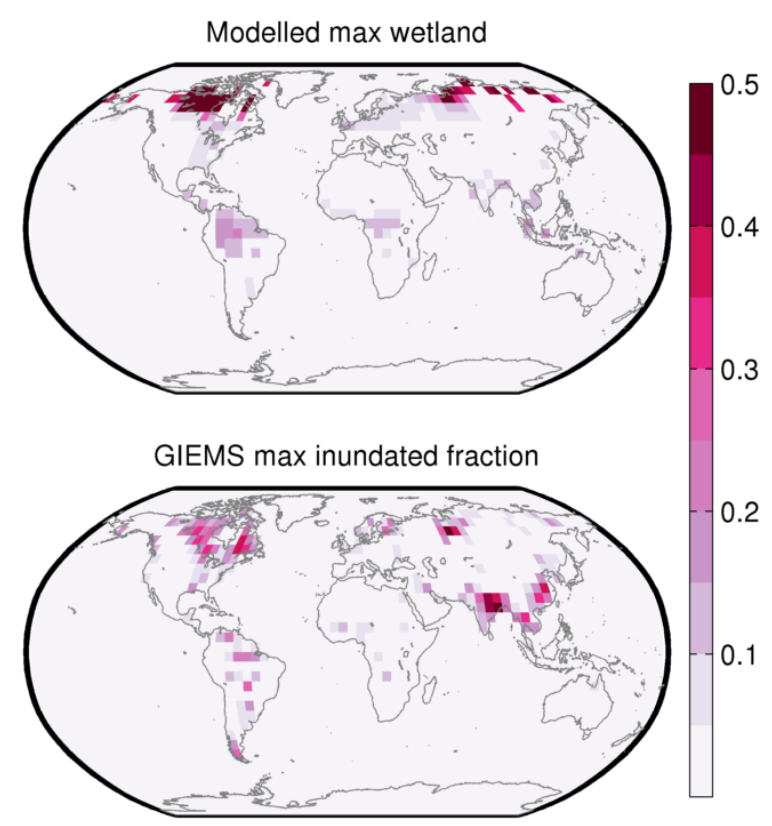

Figure 11. Monthly maximum wetland fraction over the time interval 1993-2007 as modelled by PALADYN (top) and inferred by GIEMS (Prigent et al., 2007; Papa et al., 2010) (bottom).

generally in good agreement, except over the Amazon where the model underestimates GPP. However, experiments using different climate forcings show a much better agreement between modelled and observed GPP over the Amazon basin, similarly to what shown by Lasslop et al. (2014) (not shown). The simulated global annual GPP of $133 \mathrm{PgCyr}^{-1}$ is in the upper range of current estimates (Table 8).

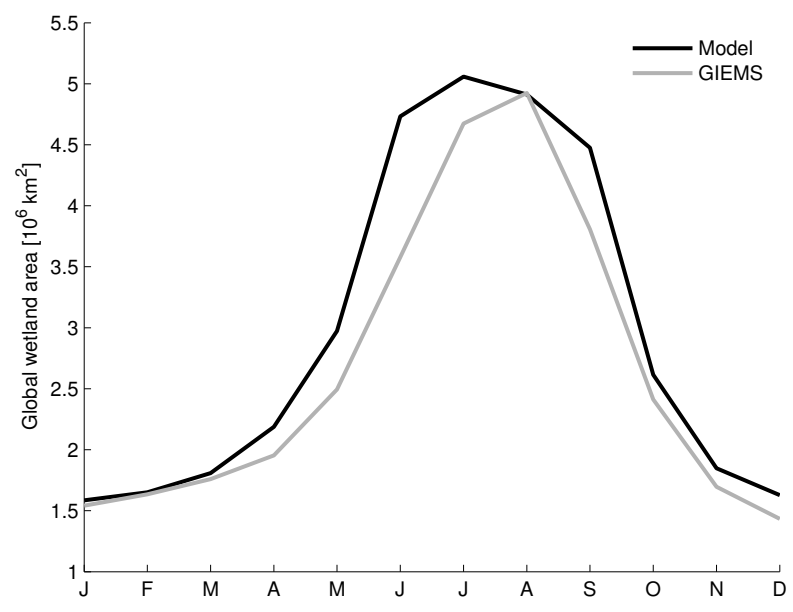

Figure 12. Mean seasonal global wetland extent over the time interval 1993-2007 as modelled by PALADYN and inferred by GIEMS (Prigent et al., 2007; Papa et al., 2010).

The net global land carbon flux over the time period 19592010 is shown in Fig. 18. The model is able to reproduce some of the interannual variability in the net land carbon uptake, indicating that the sensitivities of net primary production and soil respiration to interannual climate variations are reasonably well represented in the model.

The modelled potential vegetation distribution for the present day is shown in Fig. 19, where it is compared to potential vegetation estimates from Ramankutty and Foley (1999). In general, the model has the tendency to overestimate the areas covered by broadleaf trees in the tropics. The boreal needleleaf forest is well reproduced by the 


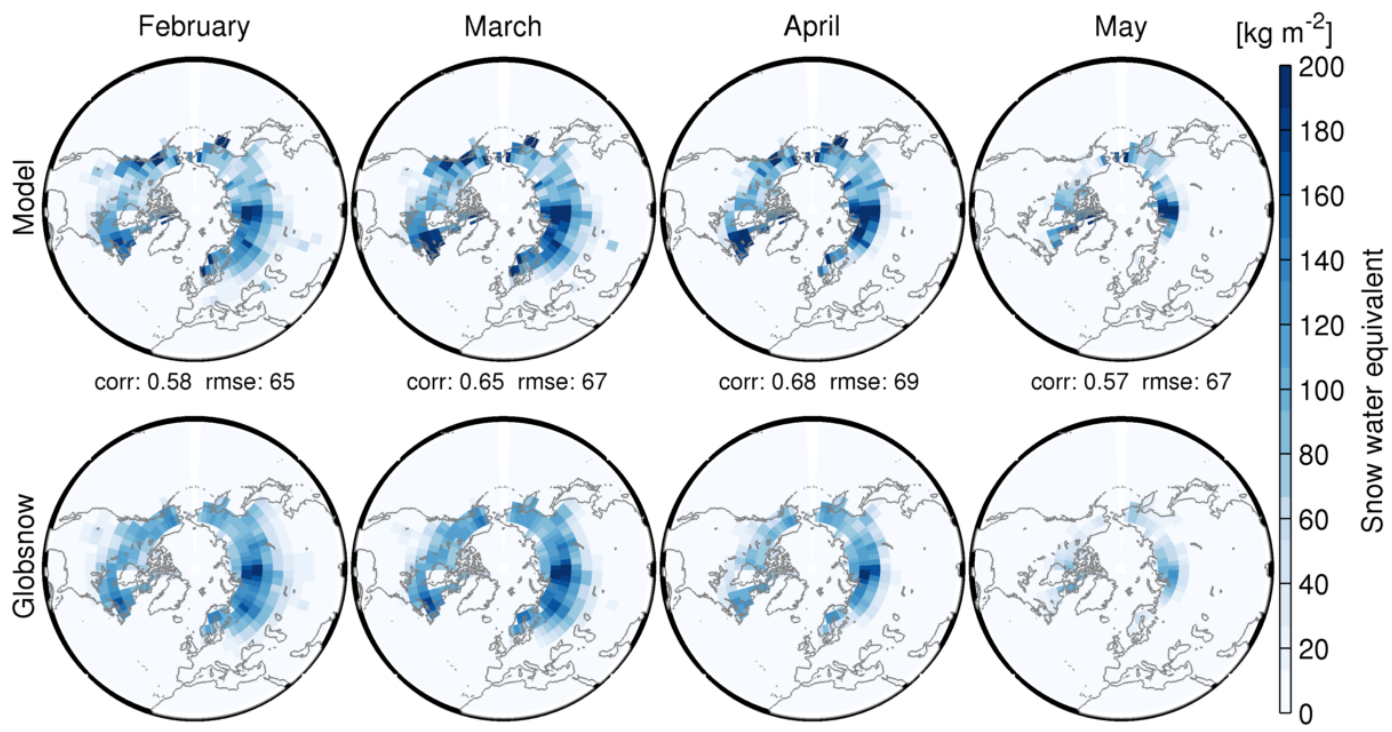

Figure 13. February to May snow water equivalent mean over the period 1980-2010 for PALADYN (top) compared to data from the GlobSnow project (Takala et al., 2011; Luojus et al., 2013) (bottom). Spatial correlation between model and data (corr) and RMSE are indicated in the top panels.

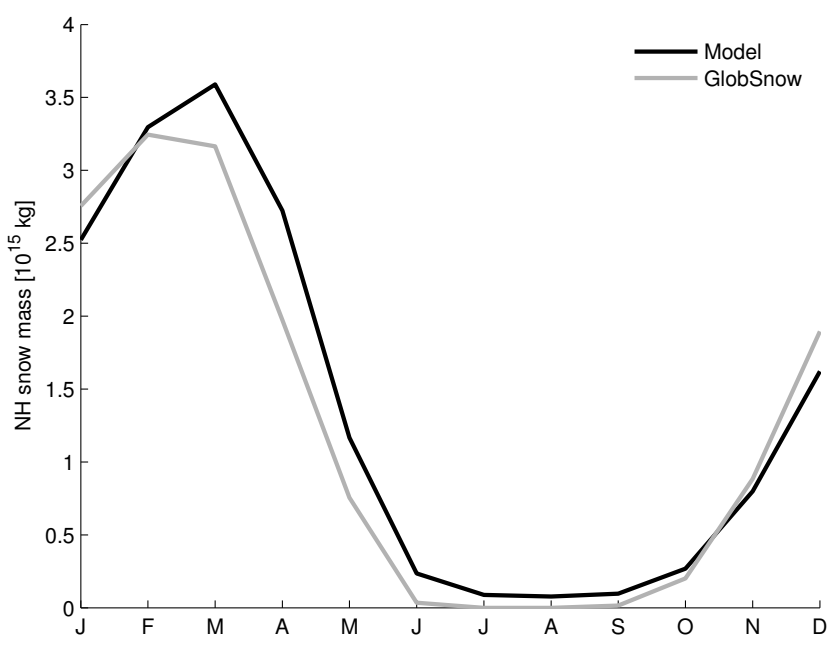

Figure 14. Mean 1980-2010 seasonal evolution of the total Northern Hemisphere snow mass compared to data from the GlobSnow project (Takala et al., 2011; Luojus et al., 2013).

model. PALADYN tends to overestimate the shrub coverage, particulary over the $\mathrm{NH}$, while the area covered by grasslands is lower than in Ramankutty and Foley (1999). Desert area is overestimated over Australia. Since vegetation cover strongly depends on the amount of precipitation, it is useful to evaluate the ability of the model to reproduce the observed PFT distribution as a function of precipitation (Zeng et al., 2008). The modelled bare soil fraction as a function of annual precipitation perfectly matches the observed distribution (Fig. 20). As opposed to observations, the model tends to simulate more grass than shrubs in arid regions. Where an-

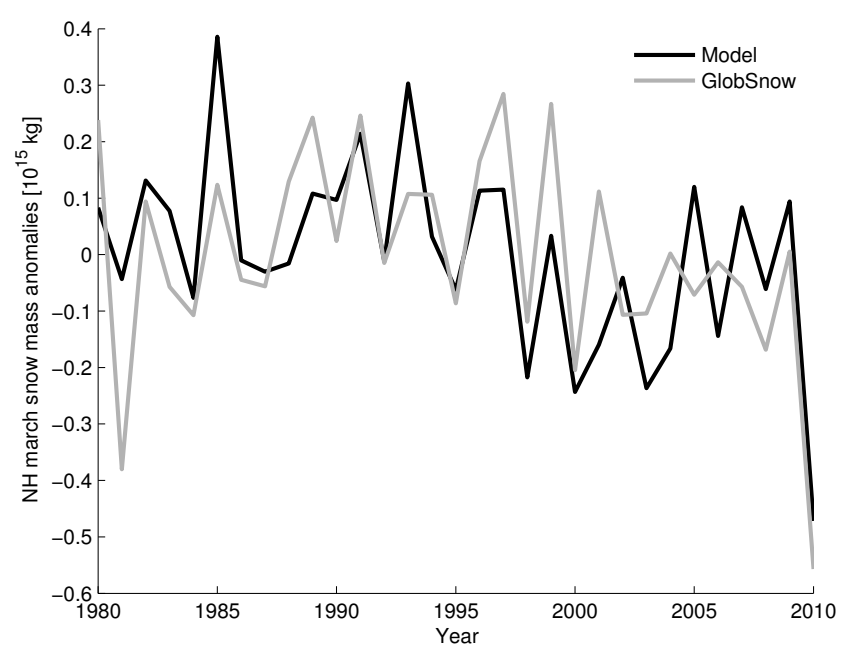

Figure 15. Northern Hemisphere March snow mass anomalies from 1980 to 2010 compared to data from the GlobSnow project (Takala et al., 2011; Luojus et al., 2013).

nual precipitation exceeds $\approx 500 \mathrm{~mm} \mathrm{yr}^{-1}$ trees start to become the dominant PFT, both in model and observations. In addition to the five PFTs represented in PALADYN, the land cover dataset from MODIS, which is used as a reference in Fig. 20, also includes savanna as a land cover type. In the model, the space covered by savanna is mostly occupied by forests, but partly also by shrubs and to a lesser extend by grasslands. Overall the sensitivity of the different PFTs to precipitation is well captured by the model. 


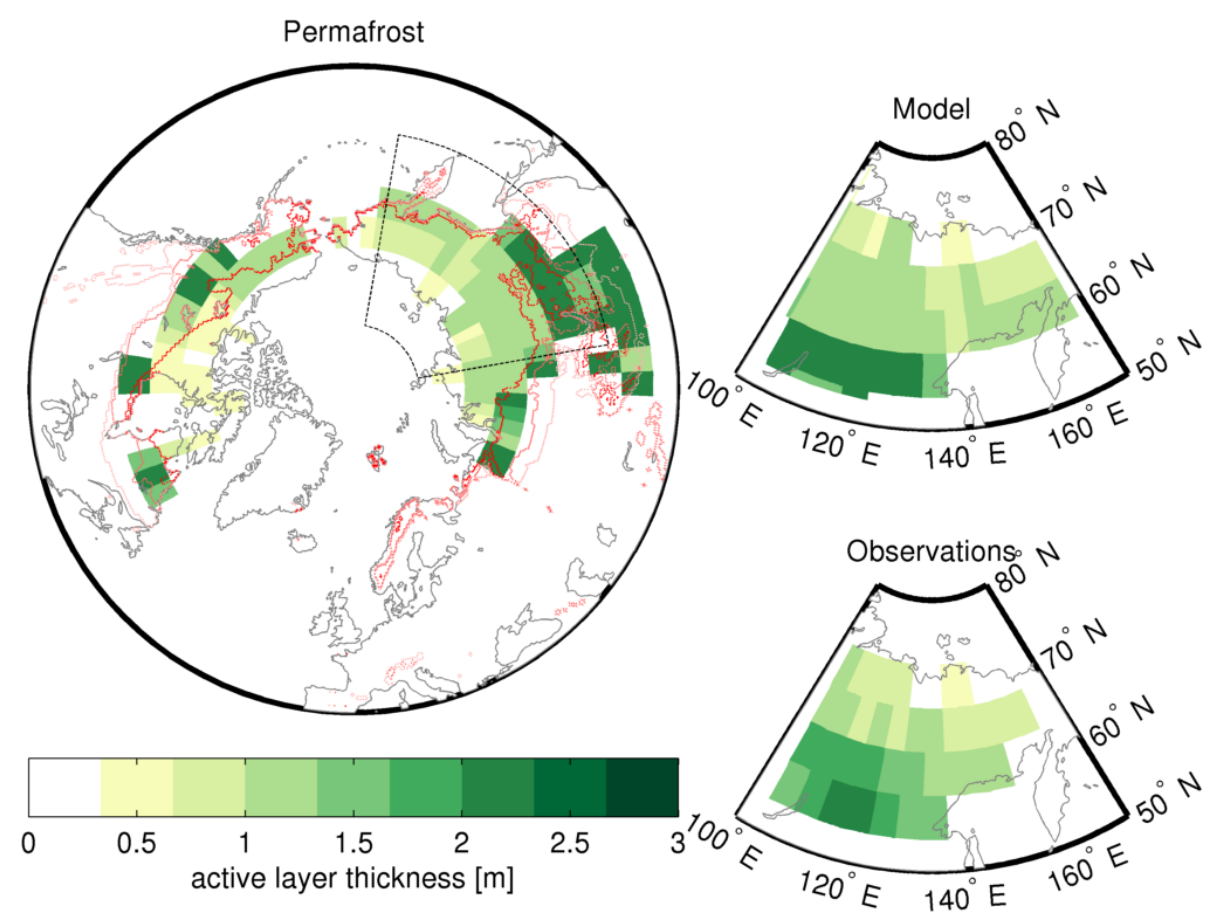

Figure 16. Left: modelled permafrost extent and active layer thickness compared to the observed extent of continuous, discontinuous and isolated permafrost (red lines, from dark red to light red) from Brown et al. (1998). Right: comparison of modelled (top) and observed (bottom) active layer thickness over Yakutia. Active layer thickness data are from Beer et al. (2013). The modelled active layer thickness is calculated as the mean over the period 1981-2010 in grid cells that are permafrost during the whole time period.

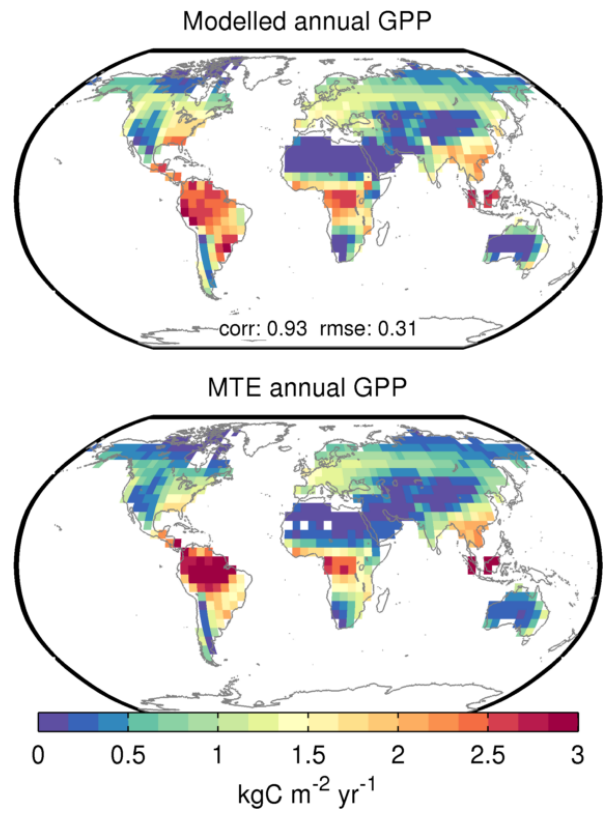

Figure 17. Mean annual gross primary production (GPP) over the time interval 1980-2010 as modelled by PALADYN (top) and estimated by the model tree ensemble approach (MTE) (Jung et al., 2009, 2011) (bottom). Spatial correlation between model and data (corr) and RMSE are indicated in the top panel.

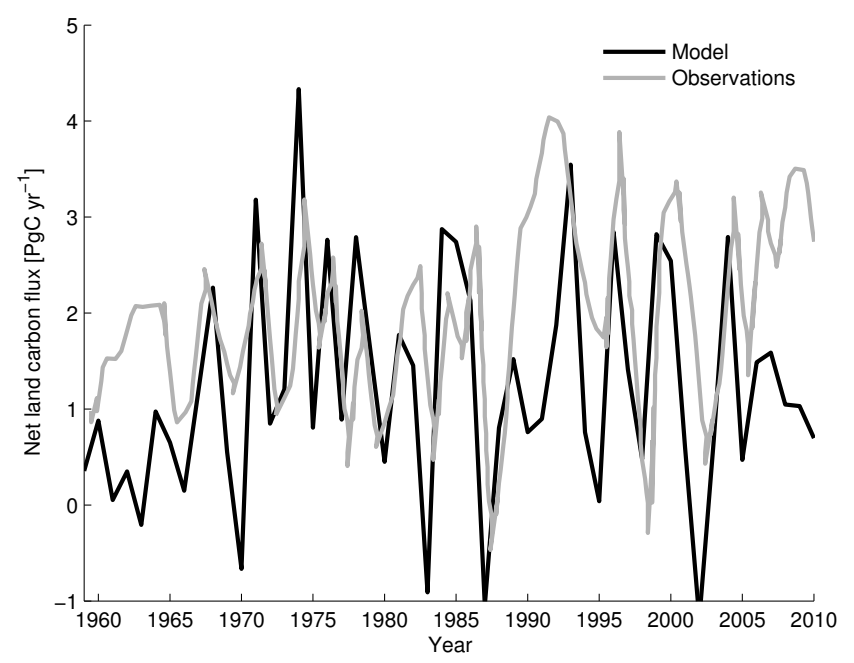

Figure 18. Net land carbon uptake for the historical simulation compared to observations from IPCC. 

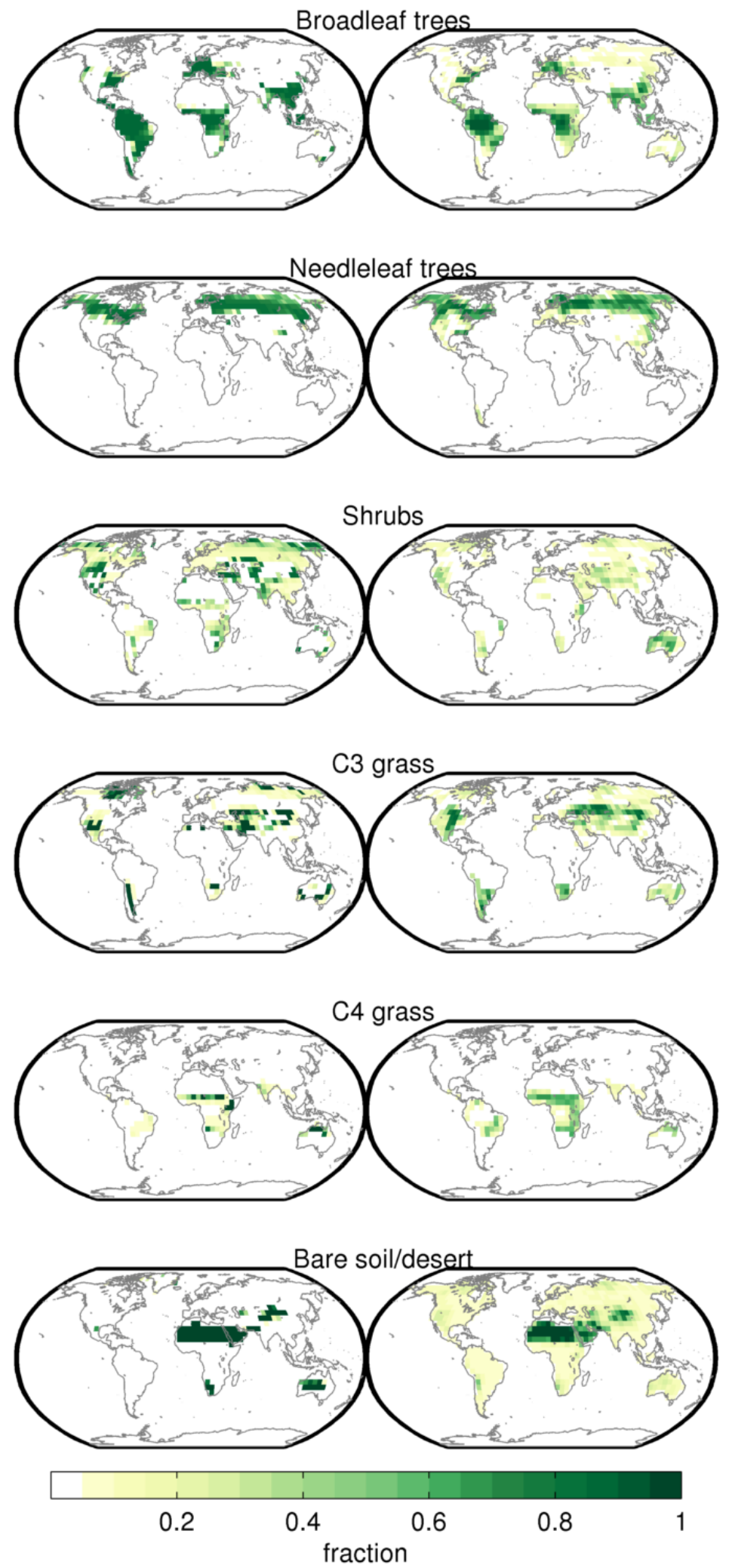

Figure 19. Comparison of modelled plant functional types fraction (left) with potential vegetation distribution adapted from Ramankutty and Foley (1999) as described in Appendix D (right). 

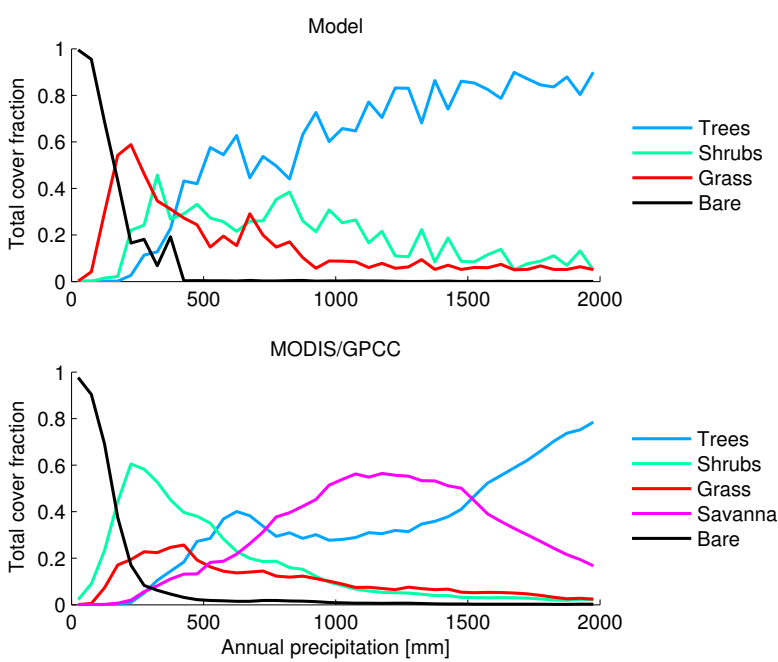

Figure 20. The dependence of the average percent coverages of PFTs on annual precipitation in the model (top) compared to land cover data from MODIS (Friedl et al., 2010; Channan et al., 2014) and precipitation from GPCC (Schneider et al., 2014) (bottom). MODIS data are at $1 \mathrm{~min}$ spatial resolution and GPCC data are interpolated to the MODIS data grid from the original $1^{\circ}$ resolution. MODIS data additionally include savanna as a land cover type, which is not included in the model.
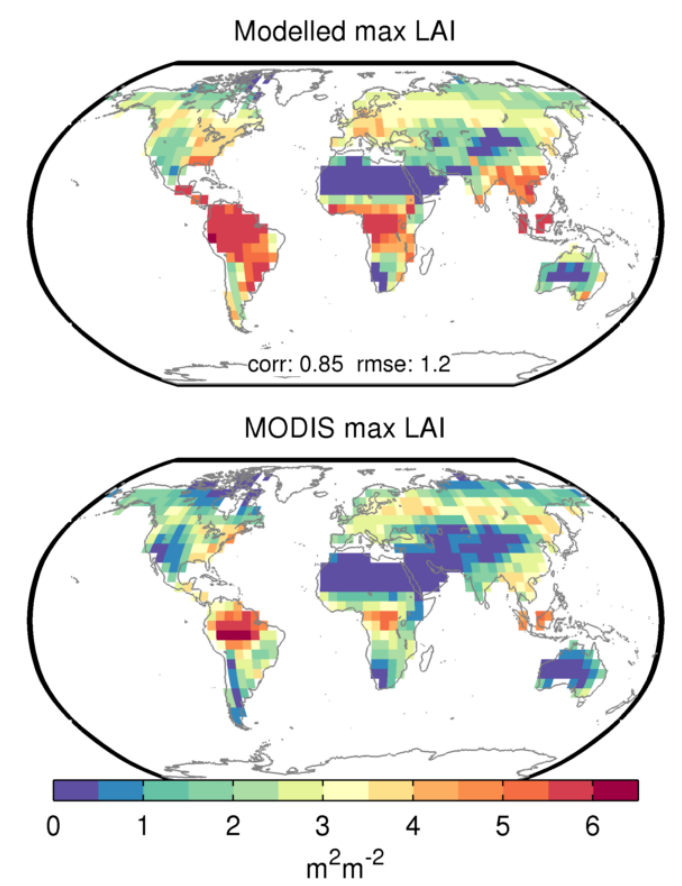

Figure 21. Comparison of modelled maximum annual leaf area index (top) with observational estimates from MODIS (Yuan et al., 2011) (bottom). Spatial correlation between model and data (corr) and RMSE are indicated in the top panel.

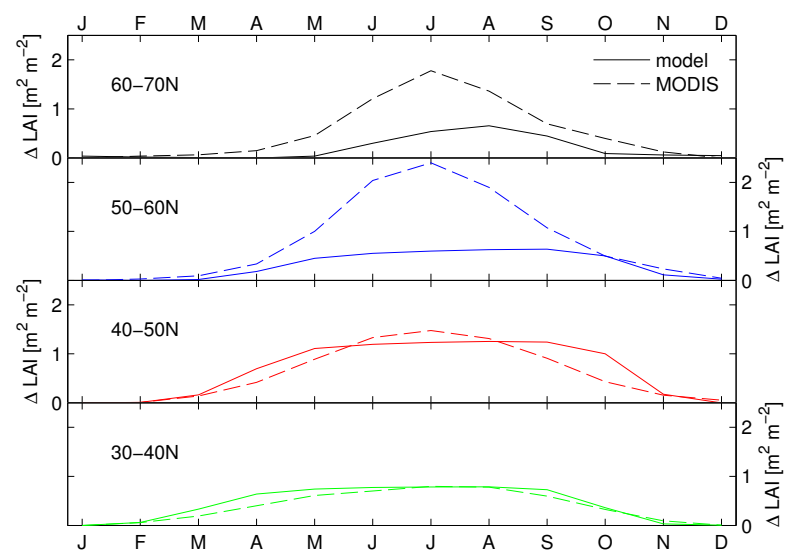

Figure 22. Seasonality of leaf area index for different latitudinal bands in the Northern Hemisphere as indicated in the individual panels. The modelled seasonality (continuous lines) is compared to MODIS data (dashed lines) (Yuan et al., 2011).

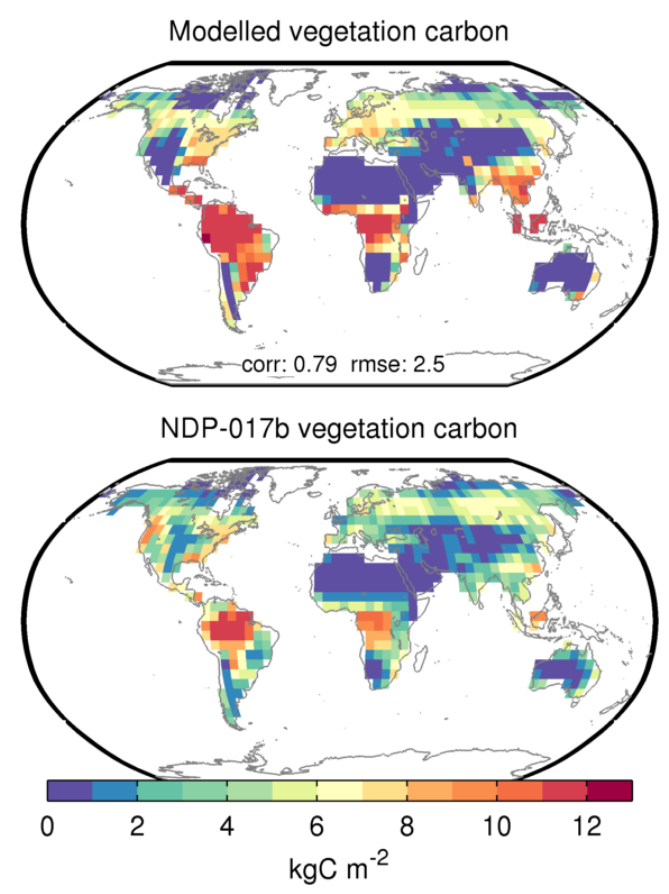

Figure 23. Comparison of modelled vegetation carbon content (top) with the observational estimates from the NDP-017b dataset (Gibbs, 2006) (bottom). Spatial correlation between model and data (corr) and RMSE are indicated in the top panel. 


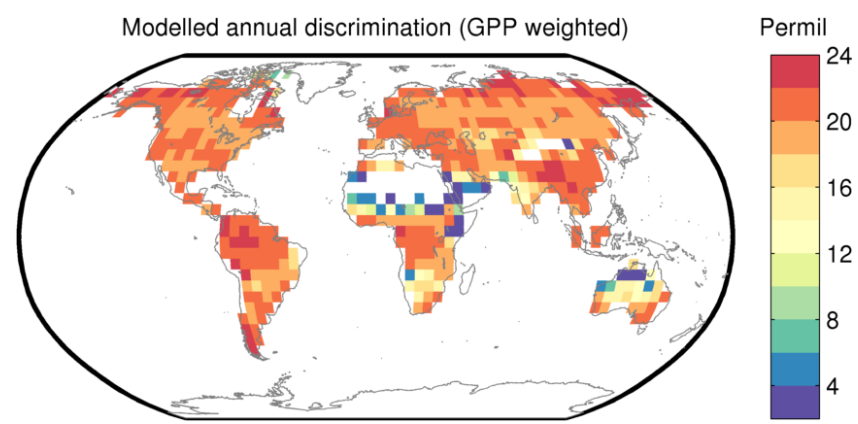

Figure 24. Modelled annual flux-weighted discrimination during photosynthesis.

The annual maximum leaf area index is compared to estimates from MODIS (Yuan et al., 2011) in Fig. 21. The modelled maximum LAI is generally higher than in MODIS, particularly in the Tropics, in high northern latitudes and in arid regions. The seasonality of the leaf area index over the Northern Hemisphere is well simulated at latitudes south of $50^{\circ} \mathrm{N}$, but is largely underestimated north of $50^{\circ} \mathrm{N}$ (Fig. 22) compared to MODIS data. This is because the latitudinal belt between 50 and $70^{\circ} \mathrm{N}$ is dominated by evergreen needleleaf forests which have no LAI seasonality in the model, while MODIS LAI is close to zero almost everywhere in high northern latitudes during winter. The reduced LAI seasonality over the boreal forest compared to observations is a common feature of many LSMs (Murray-Tortarolo et al., 2013) and is possibly an artifact of poor satellite data quality during winter (Yuan et al., 2011).

Global modelled vegetation carbon is $580 \mathrm{PgC}$, comparable to observations (Table 8). The geographic distribution of vegetation carbon content is in good agreement with data from Gibbs (2006) (Fig. 23), but is overestimated in tropical forests and underestimated in arid regions.

The annual mean GPP-weighted isotopic discrimination during photosynthesis is shown in Fig. 24. As expected, the lowest values are found in regions dominated by $\mathrm{C} 4$ grasses in subtropical Africa and Australia. The highest discrimination values are found in the tropical forests and in high northern latitudes, similar to the results shown in Scholze et al. (2003). Mean discrimination for each plant functional type is also compared with observations from Kaplan et al. (2002) in Fig. 25. The model successfully reproduces the observed differences in discrimination between different PFTs, although it tends to consistently overestimate the discrimination for all PFTs.

Top metre soil carbon from the HSWD dataset (FAO/IIASA/ISRIC/ISSCAS/JRC, 2012) is well reproduced by the model in the tropics (Fig. 26). In high northern latitudes, the model carbon content is higher than in the HSWD dataset (Fig. 26) but lower than in the NCSCD soil carbon dataset for the permafrost region (Hugelius et al., 2013a, b; Tarnocai et al., 2009) (Fig. 27). The model

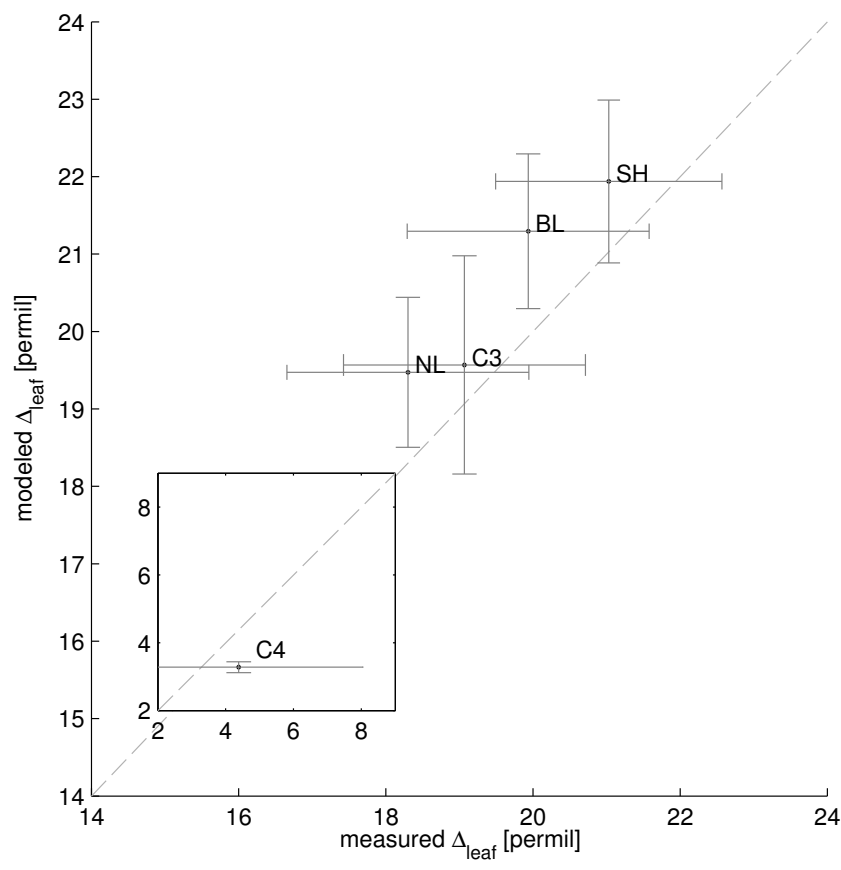

Figure 25. Comparison of modelled and observed discrimination during photosynthesis for different plant functional types. Observational data are from Kaplan et al. (2002).
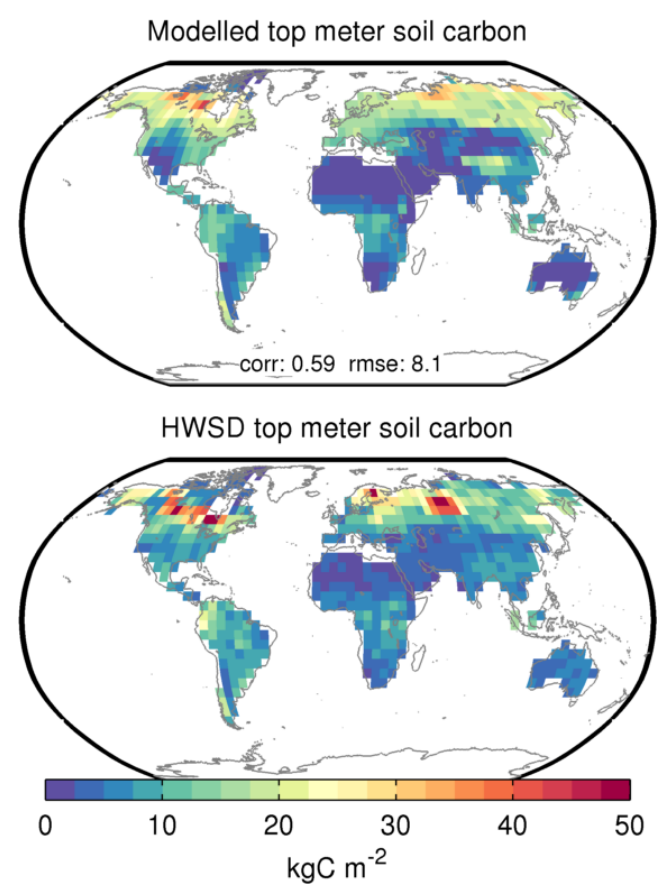

Figure 26. Top $1 \mathrm{~m}$ soil carbon as modelled by PALADYN (top) and derived from the Harmonized World Soil Database (FAO/IIASA/ISRIC/ISSCAS/JRC, 2012) (bottom). Spatial correlation between model and data (corr) and RMSE are indicated in the top panel. 

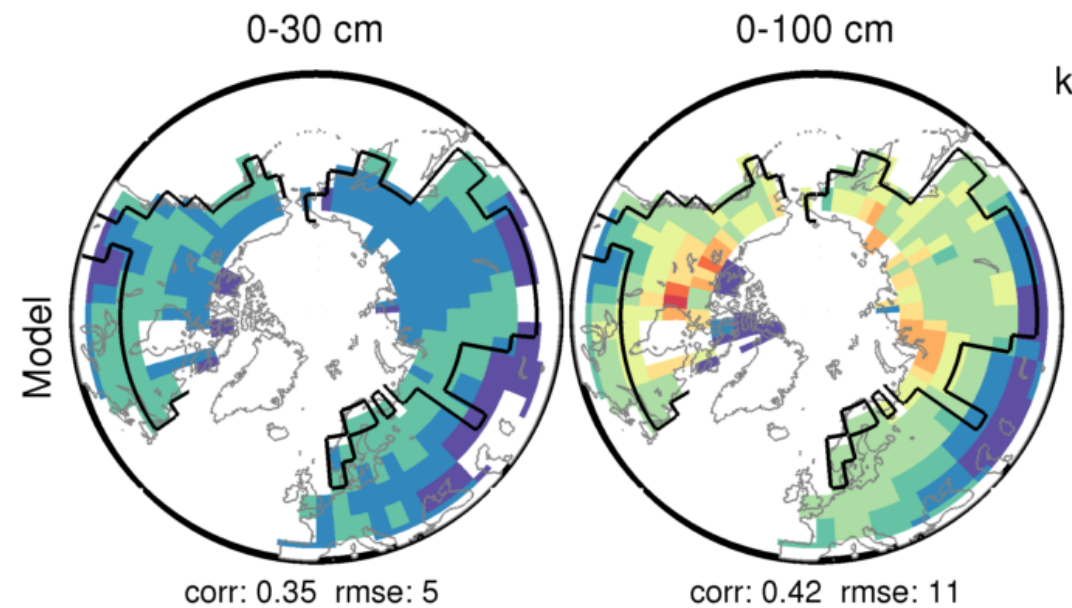

$\mathrm{kgC} \mathrm{m}^{-2}$
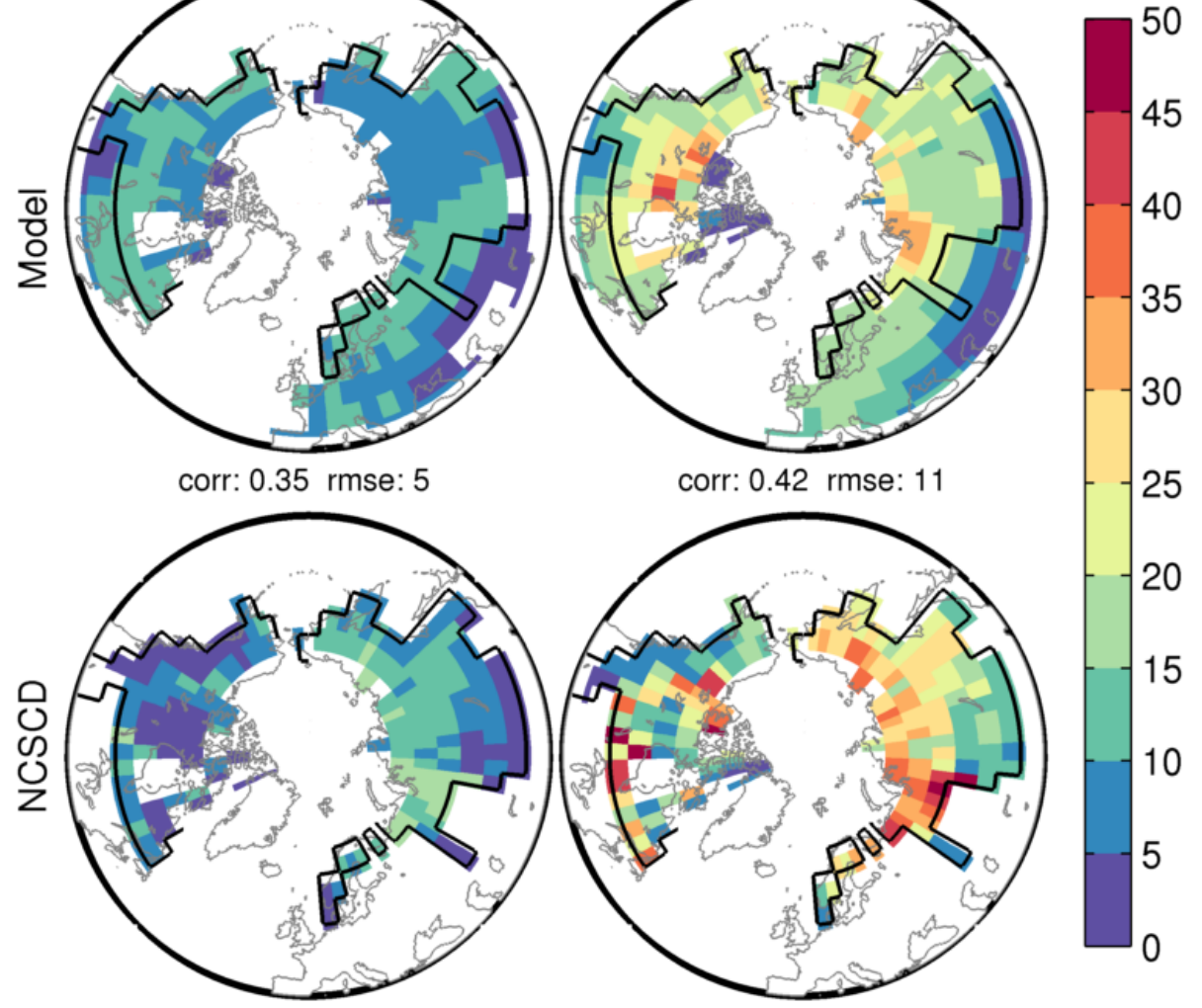

$-40$

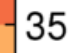

30

25

20

15

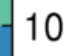

$-5$

Figure 27. Comparison of modelled (top) soil carbon in northern permafrost regions with estimates from the Northern Circumpolar Soil Carbon Database (NCSCD) (Hugelius et al., 2013a, b; Tarnocai et al., 2009) (bottom) for two depth ranges: (left) 0-30 cm and (right) $0-100 \mathrm{~cm}$. Spatial correlation between model and data (corr) and RMSE are indicated between the panels.

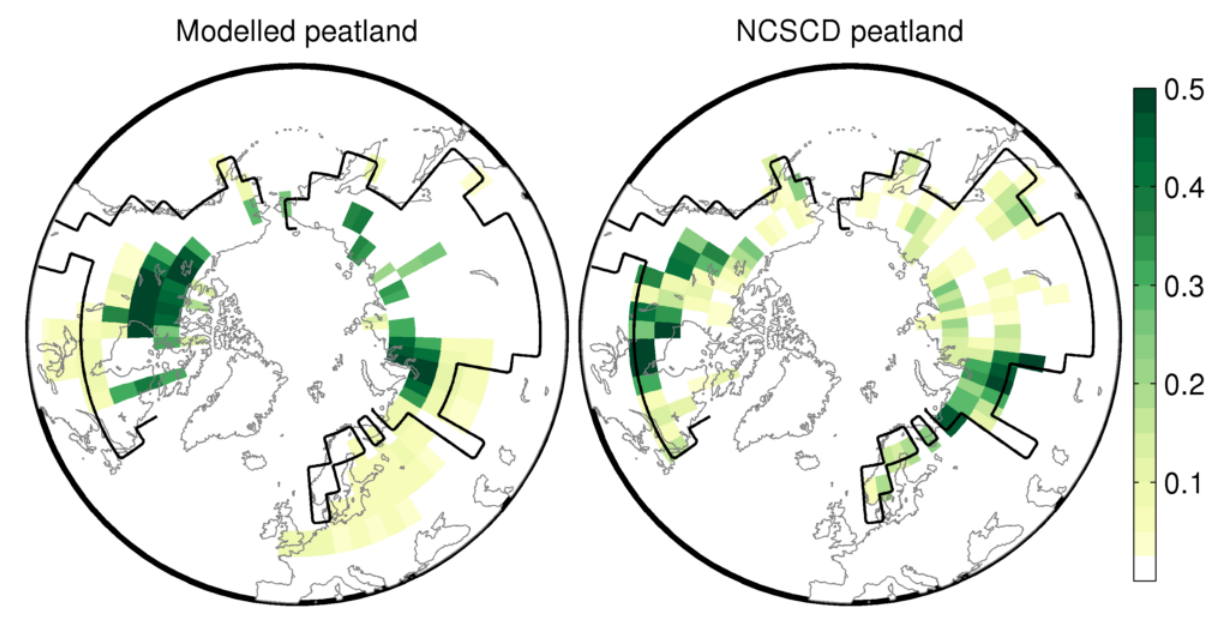

Figure 28. Peat fraction as modelled by PALADYN (left) compared to estimates from the Northern Circumpolar Soil Carbon Database (NCSCD) (Hugelius et al., 2013a, b; Tarnocai et al., 2009) (right). The permafrost area as defined in NCSCD is shown as a black line. No data are available from the NCSCD dataset outside this area. 


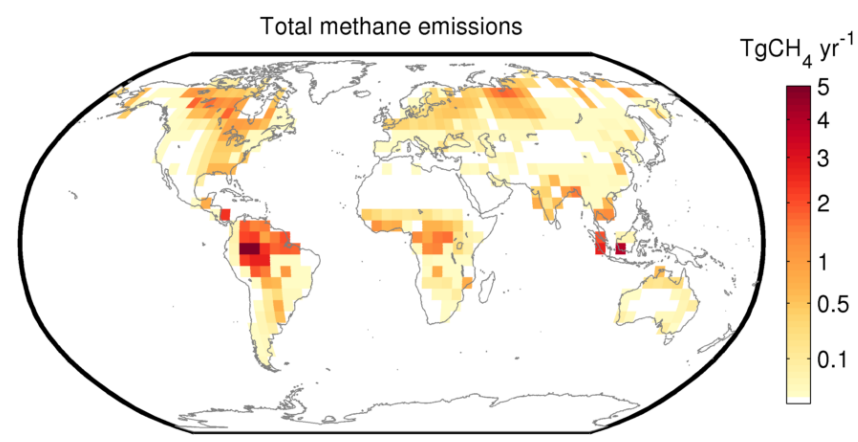

Figure 29. Modelled annual methane emissions.

underestimates carbon in peatland areas of the NH. Northern permafrost areas store large amounts of carbon at depths greater than $1 \mathrm{~m}$. The NCSCD soil carbon dataset contains estimates of soil carbon down to a depth of $3 \mathrm{~m}$ in the permafrost regions. As expected, the model in the setup used in the presented simulations can not reproduce the large amounts of carbon stored in perennially frozen ground below $1 \mathrm{~m}$ because the inert permafrost carbon pool is not included (not shown). To get the carbon accumulation in permafrost, a transient simulation over at least the last glacial cycle would be required. This is beyond the scope of this work, but will be discussed in a future paper. Similarly to the discussion on permafrost carbon, a proper estimate of peatland area and carbon content would also require a long transient simulation. However, an attempt has been made to estimate the peatland area and carbon using the equilibrium spinup described above. The estimated peatland area from this idealized approach is compared to NCSCD data (Hugelius et al., 2013a, b; Tarnocai et al., 2009) in Fig. 28.

Total modelled natural methane emissions for the present day are $160 \mathrm{TgCH}_{4} \mathrm{yr}^{-1}$. From these, $86 \mathrm{TgCH}_{4} \mathrm{yr}^{-1}$ are from the tropics and $72 \mathrm{TgCH}_{4} \mathrm{yr}^{-1}$ from the extratropics. These values compare well with recent estimates of natural methane emissions (Table 8). The spatial distribution of annual methane emissions is shown in Fig. 29.

\section{Conclusions}

The PALADYN model presented here represents a new tool to model the land processes which are relevant for climate and the carbon cycle on timescales from years to millions of years.

PALADYN serves as a land surface scheme, soil model, dynamic vegetation model and land carbon cycle model. It also includes a representation of peatlands and soil carbon pools in frozen ground. Compared to other land surface models, it has the great advantage that all components are consistently coupled.
Furthermore, PALADYN includes a representation of the processes related to changes in land-ice-shelf area, making it suitable for simulations over timescales where sea level and ice sheet areas can not be considered as fixed boundary conditions. PALADYN is therefore designed to be included in Earth system models of intermediate complexity.

On a single CPU the model in its standard configuration (daily time step, $5 \times 5^{\circ}$ horizontal resolution and five soil layers) integrates 1 year in about $1 \mathrm{~s}$ (or equivalently about 100000 model years per day), allowing to simulate, e.g. one glacial cycle in 1 day. It is therefore indicated for paleoclimate applications or to perform large ensembles of simulations to explore uncertainties and sensitivities.

PALADYN in its offline version has been shown to perform well at reproducing a number of key characteristics of the present-day land surface, soil, vegetation and land carbon cycle and is therefore ready to be included in Earth system models in a coupled setup.

\section{Code availability}

The model code is available upon request from the authors.

\section{Data availability}

The ISLSCP II Monthly Background Soil Reflectance from Dazlich and Los (2009) is available from doi:10.3334/ORNLDAAC/956. The Harmonized World Soil Database from FAO/IIASA/ISRIC/ISSCAS/JRC (2012) can be accessed at http://webarchive.iiasa.ac.at/ Research/LUC/External-World-soil-database/HTML/.

The Global Soil Dataset for Earth System Modeling from Shangguan et al. (2014) can be accessed at http://globalchange.bnu.edu.cn/research/soilw. ERA-Interim reanalysis data from Dee et al. (2011) are available at http://apps.ecmwf.int/datasets/data/interim-full-daily/.

GPCC precipitation data from Schneider et al. (2014) are available at the GPCC homepage http://gpcc.dwd.de. The ice core $\mathrm{CO}_{2}$ record from Bereiter et al. (2015) can be downloaded from http://www.ncdc.noaa.gov/paleo/study/17975 and annual $\mathrm{CO}_{2}$ concentration data for Mauna Loa from Keeling et al. (1976) are available at http://www.esrl.noaa.gov/gmd/ccgg/trends/full.html.

MODIS surface albedo from Schaaf and Wang (2015) data are available at doi:10.5067/MODIS/MCD43C3.006. The merged benchmark synthesis product of evapotranspiration of Mueller et al. (2013) is available after registration at http://www.iac.ethz.ch/group/land-climate-dynamics/ research/landflux-eval.html. The UNH/GRDC Global Composite Runoff Fields - V1.0 (Fekete et al., 2002) are accessible at http://www.compositerunoff.sr.unh.edu/ html/Data/index.html. The ESA CCI soil moisture dataset from Liu et al. (2012) is available after registration at http: //www.esa-soilmoisture-cci.org/node/145. The GlobSnow 
snow water equivalent dataset from Luojus et al. (2013) can be downloaded from http://www.globsnow.info/swe/. The circum-arctic map of permafrost and ground ice conditions from Brown et al. (1998) is available at http://nsidc.org/data/docs/fgdc/ggd318_map_circumarctic/. The active-layer thickness of Yakutia from Beer et al. (2013) is available at doi:10.1594/PANGAEA.808240. The GPP data from the MTE approach (Jung et al., 2009) can be downloaded after registration at https://www.bgc-jena.mpg.de/geodb/projects/Data.php.

The MODIS land cover data from Channan et al. (2014) are accessible at ftp://ftp.glcf.umd.edu/glcf/Global_ LNDCVR/UMD_TILES/Version_5.1/. The MODIS leaf area index from Yuan et al. (2011) data are available after registration at http://globalchange.bnu.edu.cn/ research/lai/lai_download.jsp. The NDP-017b vegetation carbon data from Gibbs (2006) can be accessed at doi:10.3334/CDIAC/lue.ndp017.2006. The Northern Circumpolar Soil Carbon Database (NCSCD) from Hugelius et al. (2013b) is accessible at doi:10.5879/ECDS/00000002. 


\section{Appendix A: Snow age factor}

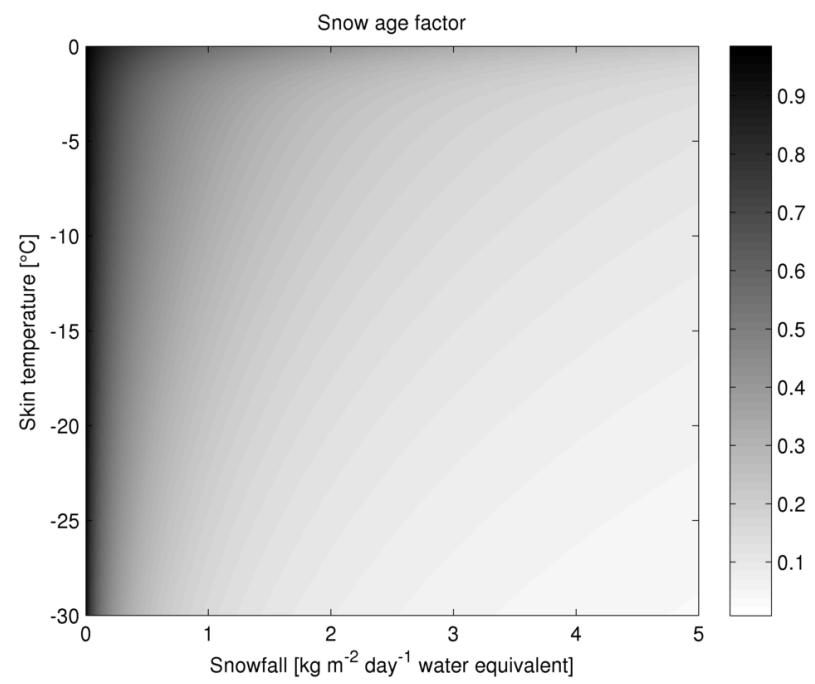

Figure A1. Snow age factor as a function of skin temperature and snowfall rate.

The snow age factor, $f_{\text {age }}$, is parameterized as a function of skin temperature and snowfall rate $P_{\mathrm{s}}$ as

$$
\begin{aligned}
& f_{\text {age }}=1-\frac{\ln \left(1+f_{\text {age }}^{\mathrm{T}} \frac{P_{\mathrm{s}, \mathrm{c}}}{P_{\mathrm{s}}}\right)}{f_{\text {age }}^{\mathrm{T}} \frac{P_{\mathrm{s}, \mathrm{c}}}{P_{\mathrm{s}}}}, \\
& f_{\text {age }}^{\mathrm{T}}=e^{0.05\left(T_{*}-T_{0}\right)}+e^{\left(T_{*}-T_{0}\right)} .
\end{aligned}
$$

The dependence of $f_{\text {age }}$ on temperature and snowfall rate with $P_{\mathrm{s}, \mathrm{c}}=2 \times 10^{-5} \mathrm{~kg} \mathrm{~m}^{-2} \mathrm{~s}^{-1}$ is shown in Fig. A1.

\section{Appendix B: Soil thermal and hydraulic properties}

Organic matter alters soil thermal and hydraulic properties substantially, in particular because of the much higher porosity of organic soils compared to mineral soils. The importance of accounting for organic matter in land surface models has been discussed in, e.g. Rinke et al. (2008), Lawrence and Slater (2008), Koven et al. (2009), Ekici et al. (2014) and Chadburn et al. (2015). In PALADYN, the fraction of soil that is considered to be organic for the determination of the thermal and hydraulic soil properties is computed in each soil layer from the total carbon density following Lawrence and Slater (2008):

$f_{\text {org }}=\min \left(1, \frac{C_{\text {lit }}+C_{\text {fast }}+C_{\text {slow }}}{\rho_{\text {org }}^{\max }}\right)$.

$\rho_{\text {org }}^{\max }=50 \mathrm{kgCm}^{-3}$ is the maximum soil carbon density, equivalent to a typical carbon density of peat.

Soil thermal and hydraulic properties are simply taken to be a linear combination of mineral and organic values based on $f_{\text {org }}$. This linear combination is applied to porosity $\left(\theta_{\text {sat }}\right)$, dry thermal conductivity $\left(\lambda_{\text {dry }}\right)$, solid soil thermal conductivity $\left(\lambda_{\mathrm{s}}\right)$, saturated hydraulic conductivity $\left(k_{\mathrm{sat}}\right)$, saturation matric potential $\left(\psi_{\mathrm{sat}}\right)$ and $b$ parameter.

Mineral soil properties are computed from sand and clay fractions following Lawrence and Slater (2008), based on Cosby et al. (1984), Farouki (1981) and Clapp and Hornberger (1978). Sand and clay fractions are taken from either FAO/IIASA/ISRIC/ISSCAS/JRC (2012) or from Shangguan et al. (2014), with the former set as default. Sand and clay fractions are considered to be vertically uniform in each grid cell and constant in time.

Organic soil properties are also taken from Lawrence and Slater (2008), partly based on Letts et al. (2000) and Farouki (1981).

\section{Appendix C: Photosynthesis}

The maximum daily rate of net photosynthesis $V_{\mathrm{m}}$ is given by

$$
V_{\mathrm{m}}=\frac{1}{a_{\mathrm{C} 3 / 4}} \frac{c_{1}}{c_{2}}\left[\left(2 \theta_{\mathrm{r}}-1\right) s-\left(2 \theta_{\mathrm{r}} s-c_{2}\right) \sigma_{\mathrm{m}}\right] \mathrm{APAR} .
$$

$\sigma_{\mathrm{m}}=\sqrt{1-\frac{c_{2}-s}{c_{2}-\theta_{\mathrm{r}} \cdot s}}$

where

$s=\frac{24}{d_{\mathrm{h}}} a_{\mathrm{C} 3 / 4}$,

and $d_{\mathrm{h}}$ is the day length in hours computed from orbital parameters.

All PALADYN PFTs follow the $\mathrm{C} 3$ photosynthetic pathway, except $\mathrm{C} 4$ grasses which follow the $\mathrm{C} 4$ pathway. For $\mathrm{C} 3$ plants, $c_{1}$ and $c_{2}$ are given by

$c_{1}=\alpha_{\mathrm{C} 3} f_{\mathrm{temp}} C_{\text {mass }} \frac{p_{\mathrm{i}}-\Gamma_{*}}{p_{\mathrm{i}}+\Gamma_{*}}$,

$c_{2}=\frac{p_{\mathrm{i}}-\Gamma_{*}}{p_{\mathrm{i}}+K_{\mathrm{c}}\left(1+\left[\mathrm{O}_{2}\right] / K_{\mathrm{o}}\right)}$.

$\alpha_{\mathrm{C} 3}=0.08$ is the intrinsic quantum efficiency of $\mathrm{CO}_{2}$ uptake in C3 plants and $C_{\text {mass }}=12$ is the atomic mass of carbon. $\Gamma_{*}$ is the $\mathrm{CO}_{2}$ compensation point:

$\Gamma_{*}=\frac{\left[\mathrm{O}_{2}\right]}{2 \tau}$,

with $\left[\mathrm{O}_{2}\right]=20.9 \mathrm{kPa}$, the atmospheric $\mathrm{O}_{2}$ partial pressure. $K_{\mathrm{c}}$, $K_{\mathrm{o}}$ and $\tau$ are kinetic parameters whose temperature dependence is modelled using a Q10 relationship (Haxeltine and Prentice, 1996a). $f_{\text {temp }}$ is a PFT-specific temperature inhibition function (Sitch et al., 2003). 
For $\mathrm{C} 4$ plants, the same equations are used but with $c_{1}$ and $c_{2}$ given by

$c_{1}=\alpha_{\mathrm{C} 4} f_{\text {temp }}$,

$c_{2}=1$.

$\alpha_{\mathrm{C} 4}=0.053$ is the intrinsic quantum efficiency of $\mathrm{CO}_{2}$ uptake in $\mathrm{C} 4$ plants.

\section{Appendix D: Aggregation of potential vegetation}

In order to compare the modelled with the potential vegetation distribution of Ramankutty and Foley (1999), the potential vegetation needs to be aggregated to the plant functional types represented in PALADYN. We partly follow Blyth et al. (2011) and map vegetation classes of Ramankutty and Foley (1999) to the PALADYN PFTs as described in Table D1. The grass class in Table D1 is divided into C3 and C4 grasses based on the modelled grass type in each grid cell.

Table D1. Mapping of Ramankutty and Foley (1999) potential vegetation classes to PALADYN PFTs.

\begin{tabular}{lccccc}
\hline & BL & NL & Grass & Shrubs & Bare soil \\
\hline Tropical evergreen & 0.9 & 0.0 & 0.0 & 0.0 & 0.1 \\
Tropical deciduous & 0.8 & 0.0 & 0.1 & 0.0 & 0.1 \\
Temperate broadleaved evergreen & 0.9 & 0.0 & 0.0 & 0.0 & 0.1 \\
Temperate needleleaved evergreen & 0.0 & 0.9 & 0.0 & 0.0 & 0.1 \\
Temperate deciduous & 0.9 & 0.0 & 0.0 & 0.0 & 0.1 \\
Boreal evergreen & 0.0 & 0.9 & 0.0 & 0.0 & 0.1 \\
Boreal deciduous & 0.0 & 0.8 & 0.1 & 0.0 & 0.1 \\
Mixed evergreen/deciduous & 0.1 & 0.7 & 0.0 & 0.1 & 0.1 \\
Savanna & 0.3 & 0.0 & 0.6 & 0.0 & 0.1 \\
Grassland/steppe & 0.0 & 0.0 & 0.9 & 0.0 & 0.1 \\
Dense shrub & 0.0 & 0.0 & 0.1 & 0.8 & 0.1 \\
Open shrub & 0.0 & 0.0 & 0.2 & 0.5 & 0.3 \\
Tundra & 0.0 & 0.0 & 0.35 & 0.35 & 0.3 \\
\hline
\end{tabular}


Acknowledgements. The authors would like to thank Victor Brovkin and Daniela Dalmonech for discussions, and Catherine Pringent for providing the GIEMS dataset. M. Willeit acknowledges support by the German Science Foundation DFG grant GA 1202/2-1.

Edited by: H. Sato

Reviewed by: two anonymous referees

\section{References}

Anderson, E.: A point energy and mass balance model of a snow cover, NOAA Technical Report NWS 19, 1976.

Arora, V. K. and Boer, G. J.: Fire as an interactive component of dynamic vegetation models, J. Geophys. Res., 110, 1-20, doi:10.1029/2005JG000042, 2005.

Arora, V. K. and Boer, G. J.: Simulating competition and coexistence between plant functional types in a dynamic vegetation model, Earth Interact., 10, 1-30, doi:10.1175/EI170.1, 2006.

Ball, J. T., Woodrow, I. E., and Berry, J. A.: A Model Predicting Stomatal Conductance and its Contribution to the Control of Photosynthesis under Different Environmental Conditions, in: Progress in Photosynthesis Research, Springer Netherlands, 221-224, doi:10.1007/978-94-017-0519-6_48, 1987.

Baumgartner, A. and Reichel, E.: Die Weltwasserbilanz: Niederschlag, Verdunstung u. Abfluss über Land u. Meer sowie auf d. Erde im Jahresdurchschnitt, München, Wien, Oldenbourg, ISBN-10: 3-486-34751-9, 1975.

Beer, C., Reichstein, M., Tomelleri, E., Ciais, P., Jung, M., Carvalhais, N., Rödenbeck, C., Arain, M. A., Baldocchi, D., Bonan, G. B., Bondeau, A., Cescatti, A., Lasslop, G., Lindroth, A., Lomas, M., Luyssaert, S., Margolis, H., Oleson, K. W., Roupsard, O., Veenendaal, E., Viovy, N., Williams, C., Woodward, F. I., and Papale, D.: Terrestrial gross carbon dioxide uptake: global distribution and covariation with climate, Science, 329, 834-838, doi:10.1126/science.1184984, 2010.

Beer, C., Fedorov, A. N., and Torgovkin, Y.: Permafrost temperature and active-layer thickness of Yakutia with 0.5-degree spatial resolution for model evaluation, Earth Syst. Sci. Data, 5, 305-310, doi:10.5194/essd-5-305-2013, 2013 (data available at: doi:10.1594/PANGAEA.808240).

Bereiter, B., Eggleston, S., Schmitt, J., Nehrbass-Ahles, C., Stocker, T. F., Fischer, H., Kipfstuhl, S., and Chappellaz, J.: Revision of the EPICA Dome $\mathrm{C} \mathrm{CO}_{2}$ record from 800 to $600 \mathrm{kyr}$ before present, Geophys. Res. Lett., 42, 542-549, doi:10.1002/2014GL061957, 2015 (data available at: http:// www.ncdc.noaa.gov/paleo/study/17975).

Beven, K. J. and Kirkby, M. J.: A physically based, variable contributing area model of basin hydrology/Un modèle à base physique de zone d'appel variable de l'hydrologie du bassin versant, Hydrological Sciences Bulletin, 24, 43-69, doi:10.1080/02626667909491834, 1979.

Bloom, A. A., Palmer, I. P., Fraser, A., Reay, D. S., and Frankenberg, C.: Large-Scale Controls of Methanogenesis Inferred from Methane and Gravity Spaceborne Data, American Association for the Advancement of Science, Science, 327, 322-325, doi:10.1126/science.1175176, 2010.
Blyth, E., Clark, D. B., Ellis, R., Huntingford, C., Los, S., Pryor, M., Best, M., and Sitch, S.: A comprehensive set of benchmark tests for a land surface model of simultaneous fluxes of water and carbon at both the global and seasonal scale, Geosci. Model Dev., 4, 255-269, doi:10.5194/gmd-4-255-2011, 2011.

Bousquet, P., Ciais, P., Miller, J. B., Dlugokencky, E. J., Hauglustaine, D. A., Prigent, C., Van der Werf, G. R., Peylin, P., Brunke, E.-G., Carouge, C., Langenfelds, R. L., Lathière, J., Papa, F., Ramonet, M., Schmidt, M., Steele, L. P., Tyler, S. C., and White, J.: Contribution of anthropogenic and natural sources to atmospheric methane variability, Nature, 443, 439443, doi:10.1038/nature05132, 2006.

Braakhekke, M. C., Beer, C., Hoosbeek, M. R., Reichstein, M., Kruijt, B., Schrumpf, M., and Kabat, P.: SOMPROF: A vertically explicit soil organic matter model, Ecol. Model., 222, 17121730, doi:10.1016/j.ecolmodel.2011.02.015, 2011.

Brovkin, V., Ganopolski, A., and Svirezhev, Y.: A continuous climate-vegetation classification for use in climate-biosphere studies, Ecol. Model., 101, 251-261, 1997.

Brovkin, V., Bendtsen, J., Claussen, M., Ganopolski, A., Kubatzki, C., Petoukhov, V., and Andreev, A.: Carbon cycle, vegetation, and climate dynamics in the Holocene: Experiments with the CLIMBER-2 model, Global Biogeochem. Cy., 16, 86-1-86-20, doi:10.1029/2001GB001662, 2002.

Brovkin, V., Raddatz, T., Reick, C. H., Claussen, M., and Gayler, V.: Global biogeophysical interactions between forest and climate, Geophys. Res. Lett., 36, 1-6, doi:10.1029/2009GL037543, 2009.

Brown, J., Ferrians, O., Heginbottom, J. A., and Melnikov, E.: Circum-Arctic Map of Permafrost and Ground-Ice Conditions, National Snow and Ice Data Center, available at: http://nsidc.org/ data/docs/fgdc/ggd318_map_circumarctic (last access: 20 January 2016), 1998.

Campbell, G. S. and Norman, J. M.: The description and measurement of plant canopy structure, in: Plant Canopies: Their Growth, Form and Function, edited by: Russel, G., Marshall, B., and Jarvis, P. G., 1-19, Cambridge University Press, Cambridge, 1989.

Chadburn, S., Burke, E., Essery, R., Boike, J., Langer, M., Heikenfeld, M., Cox, P., and Friedlingstein, P.: An improved representation of physical permafrost dynamics in the JULES land-surface model, Geosci. Model Dev., 8, 1493-1508, doi:10.5194/gmd-81493-2015, 2015.

Channan, S., Collins, K., and Emanuel, W. R.: Global mosaics of the standard MODIS land cover type data, Maryland and the Pacific Northwest National Laboratory, College Park, Maryland, USA, 2014 (data available at: ftp://ftp.glcf.umd.edu/glcf/Global_ LNDCVR/UMD_TILES/Version_5.1/).

Clapp, R. B. and Hornberger, G. M.: Empirical equations for some soil hydraulic properties, Water Resour. Res., 14, 601-604, doi:10.1029/WR014i004p00601, 1978.

Clark, D. B., Mercado, L. M., Sitch, S., Jones, C. D., Gedney, N., Best, M. J., Pryor, M., Rooney, G. G., Essery, R. L. H., Blyth, E., Boucher, O., Harding, R. J., Huntingford, C., and Cox, P. M.: The Joint UK Land Environment Simulator (JULES), model description - Part 2: Carbon fluxes and vegetation dynamics, Geosci. Model Dev., 4, 701-722, doi:10.5194/gmd-4-701-2011, 2011.

Claussen, M.: On coupling global biome models with climate models, Clim. Res., 4, 203-221, doi:10.3354/cr004203, 1994. 
Claussen, M., Mysak, L., Weaver, A., Crucifix, M., Fichefet, T., Loutre, M. F., Weber, S., Alcamo, J., Alexeev, V., Berger, A., Calov, R., Ganopolski, A., Goosse, H., Lohmann, G., Lunkeit, F., Mokhov, I., Petoukhov, V., Stone, P., and Wang, Z.: Earth system models of intermediate complexity: Closing the gap in the spectrum of climate system models, Clim. Dynam., 18, 579-586, doi:10.1007/s00382-001-0200-1, 2002.

Clymo, R. S.: The Limits to Peat Bog Growth, Philos. T. R. Soc. B, 303, 605-654, doi:10.1098/rstb.1984.0002, 1984.

Clymo, R. S., Turunen, J., and Tolonen, K.: Carbon Accumulation in Peatland, Oikos, Nordic Society Oikos, Wiley, 368-388, ISSN: 00301299, ISSN: 16000706, 1998.

Collatz, G., Ball, J., Grivet, C., and Berry, J. A.: Physiological and environmental regulation of stomatal conductance, photosynthesis and transpiration: a model that includes a laminar boundary layer, Agr. Forest Meteorol., 54, 107-136, doi:10.1016/01681923(91)90002-8, 1991.

Cosby, B. J., Hornberger, G. M., Clapp, R. B., and Ginn, T. R.: A Statistical Exploration of the Relationships of Soil Moisture Characteristics to the Physical Properties of Soils, Water Resour. Res., 20, 682-690, doi:10.1029/WR020i006p00682, 1984.

Cox, P. M.: Description of the "TRIFFID" Dynamic Global Vegetation Model, Hadley Centre Technical Note 24, Hadley Centre, Met Office, Bracknell, UK, 2001.

Cox, P. M., Betts, R. A., Bunton, C. B., Essery, R. L. H., Rowntree, P. R., and Smith, J.: The impact of new land surface physics on the GCM simulation of climate and climate sensitivity, Clim. Dynam., 15, 183-203, doi:10.1007/s003820050276, 1999.

Dale, V. H., Joyce, L. A., McNulty, S., Neilson, R. P., Ayres, M. P., Flannigan, M. D., Hanson, P. H., Irland, L. C., Lugo, A. E., Peterson, C. J., Simberloff, D., Swanson, F. J., Stocks, B. J., and Wotton, M. B.: Climate change and forest disturbances, BioScience, 51, 723-734, doi:10.1641/00063568(2001)051[0723:CCAFD]2.0.CO;2, 2001.

Dazlich, D. A. and Los, S. O.: ISLSCP II Monthly SnowFree Albedo, 1982-1998, and Background Soil Reflectance, in: ISLSCP Initiative II Collection, Data set, edited by: Hall, F. G., Collatz, G., Meeson, B., Los, S., Brown de Colstoun, E., and Landis, D., available at: http://daac.ornl.gov/ (last access: 30 June 2015), Oak Ridge National Laboratory Distributed Active Archive Center, Oak Ridge, Tennessee, USA., doi:10.3334/ORNLDAAC/956, 2009.

Deardorff, J. W.: Efficient prediction of ground surface temperature and moisture, with inclusion of a layer of vegetation, J. Geophys. Res., 83, 1889, doi:10.1029/JC083iC04p01889, 1978.

Dee, D. P., Uppala, S. M., Simmons, A. J., Berrisford, P., Poli, P., Kobayashi, S., Andrae, U., Balmaseda, M. A., Balsamo, G., Bauer, P., Bechtold, P., Beljaars, A. C. M., van de Berg, L., Bidlot, J., Bormann, N., Delsol, C., Dragani, R., Fuentes, M., Geer, A. J., Haimberger, L., Healy, S. B., Hersbach, H., Hólm, E. V., Isaksen, L., Kållberg, P., Köhler, M., Matricardi, M., McNally, A. P., Monge-Sanz, B. M., Morcrette, J.-J., Park, B.-K., Peubey, C., de Rosnay, P., Tavolato, C., Thépaut, J.-N., and Vitart, F.: The ERA-Interim reanalysis: configuration and performance of the data assimilation system, Q. J. Roy. Meteor. Soc., 137, 553-597, doi:10.1002/qj.828, 2011 (data available at: http://apps.ecmwf.int/datasets/data/interim-full-daily/).

Dickinson, R., Henderson-Sellers, A., Kennedy, P., and Wilson, M.: Biosphere-Atmosphere Transfer Scheme (BATS) for the NCAR
Community Climate Model, NCAR Technical Note NCAR/TN275-+STR, doi:10.5065/D6668B58, 1986.

Dirmeyer, P. A., Gao, X., Zhao, M., Guo, Z., Oki, T., and Hanasaki, N.: GSWP-2: Multimodel Analysis and Implications for Our Perception of the Land Surface, B. Am. Meteorol. Soc., 87, 13811397, doi:10.1175/BAMS-87-10-1381, 2006.

Ekici, A., Beer, C., Hagemann, S., Boike, J., Langer, M., and Hauck, C.: Simulating high-latitude permafrost regions by the JSBACH terrestrial ecosystem model, Geosci. Model Dev., 7, 631-647, doi:10.5194/gmd-7-631-2014, 2014.

Enquist, B. J., Brown, J. H., and West, G. B.: Allometric scaling of plant energetics and population density, Nature, 395, 163-165, doi:10.1038/25977, 1998.

FAO/IIASA/ISRIC/ISSCAS/JRC: Harmonized World Soil Database (version 1.2), FAO, Rome, Italy and IIASA, Laxenburg, Austria, 2012.

Farouki, O. T.: Thermal properties of soils, Special Report 81-1, Cold Regions Research and Engineering Laboratory (CRREL), Hanover, NH, 1981.

Farquhar, G. D., Caemmerer, S., and Berry, J. A.: A biochemical model of photosynthetic $\mathrm{CO}_{2}$ assimilation in leaves of $\mathrm{C} 3$ species, Planta, 149, 78-90, doi:10.1007/BF00386231, 1980.

Fekete, B. M., Vörösmarty, C. J., and Grabs, W.: High-resolution fields of global runoff combining observed river discharge and simulated water balances, Global Biogeochem. Cy., 16, 15-1-1510, doi:10.1029/1999GB001254, 2002 (data available at: http: //www.compositerunoff.sr.unh.edu/html/Data/index.html).

Foley, J. A.: Net primary productivity in the terrestrial biosphere: The application of a global model, J. Geophys. Res., 99, 20773, doi:10.1029/94JD01832, 1994.

Foley, J. A., Prentice, I. C., Ramankutty, N., Levis, S., Pollard, D., Sitch, S., and Haxeltine, A.: An integrated biosphere model of land surface processes, terrestrial carbon balance, and vegetation dynamics, Global Biogeochem. Cy., 10, 603-628, doi:10.1029/96GB02692, 1996.

Friedl, M. A., Sulla-Menashe, D., Tan, B., Schneider, A., Ramankutty, N., Sibley, A., and Huang, X.: MODIS Collection 5 global land cover: Algorithm refinements and characterization of new datasets, 2001-2012, Collection 5.1 IGBP Land Cover, Boston University, Boston, MA, USA, 2010.

Friend, A. D., Stevens, A., Knox, R., and Cannell, M.: A processbased, terrestrial biosphere model of ecosystem dynamics (Hybrid v3.0), Ecol. Model., 95, 249-287, doi:10.1016/S03043800(96)00034-8, 1997.

Ganopolski, A., Petoukhov, V., Rahmstorf, S., Brovkin, V., Claussen, M., Eliseev, A., and Kubatzki, C.: CLIMBER2: a climate system model of intermediate complexity. Part II: model sensitivity, Clim. Dynam., 17, 735-751, doi:10.1007/s003820000144, 2001.

Gardner, A. S. and Sharp, M. J.: A review of snow and ice albedo and the development of a new physically based broadband albedo parameterization, J. Geophys. Res., 115, F01009, doi:10.1029/2009JF001444, 2010.

Garratt, J.: The Atmospheric Boundary Layer, Cambridge University Press, 316 pp,, 1994.

Gibbs, H. K.: Olson's Major World Ecosystem Complexes Ranked by Carbon in Live Vegetation: An Updated Database Using the GLC2000 Land Cover Product, available at: http: 
//cdiac.ornl.gov/epubs/ndp/ndp017/ndp017b.html (last access: 7 March 2016), doi:10.3334/CDIAC/lue.ndp017.2006, 2006.

Gruber, S.: Derivation and analysis of a high-resolution estimate of global permafrost zonation, The Cryosphere, 6, 221-233, doi:10.5194/tc-6-221-2012, 2012.

Haxeltine, A. and Prentice, I. C.: A general model for the lightuse efficiency of primary production, Funct. Ecol., 10, 551-561, $1996 \mathrm{a}$.

Haxeltine, A. and Prentice, I. C.: BIOME3: An equilibrium terrestrial biosphere model based on ecophysiological constraints, resource availability, and competition among plant functional types, Global Biogeochem. Cy., 10, 693-709, doi:10.1029/96GB02344, 1996b.

Henderson-Sellers, A.: Continental vegetation as a dynamic component of a global climate model: a preliminary assessment, Climatic Change, 23, 337-377, doi:10.1007/BF01091622, 1993.

Houldcroft, C. J., Grey, W. M. F., Barnsley, M., Taylor, C. M., Los, S. O., and North, P. R. J.: New Vegetation Albedo Parameters and Global Fields of Soil Background Albedo Derived from MODIS for Use in a Climate Model, J. Hydrometeorol., 10, 183-198, doi:10.1175/2008JHM1021.1, 2009.

Hugelius, G., Bockheim, J. G., Camill, P., Elberling, B., Grosse, G., Harden, J. W., Johnson, K., Jorgenson, T., Koven, C. D., Kuhry, P., Michaelson, G., Mishra, U., Palmtag, J., Ping, C.-L., O’Donnell, J., Schirrmeister, L., Schuur, E. A. G., Sheng, Y., Smith, L. C., Strauss, J., and Yu, Z.: A new data set for estimating organic carbon storage to $3 \mathrm{~m}$ depth in soils of the northern circumpolar permafrost region, Earth Syst. Sci. Data, 5, 393-402, doi:10.5194/essd-5-393-2013, 2013a.

Hugelius, G., Tarnocai, C., Broll, G., Canadell, J. G., Kuhry, P., and Swanson, D. K.: The Northern Circumpolar Soil Carbon Database: spatially distributed datasets of soil coverage and soil carbon storage in the northern permafrost regions, Earth Syst. Sci. Data, 5, 3-13, doi:10.5194/essd-5-3-2013, 2013b (data available at: doi:10.5879/ECDS/00000002).

Hugelius, G., Strauss, J., Zubrzycki, S., Harden, J. W., Schuur, E. A. G., Ping, C.-L., Schirrmeister, L., Grosse, G., Michaelson, G. J., Koven, C. D., O’Donnell, J. A., Elberling, B., Mishra, U., Camill, P., Yu, Z., Palmtag, J., and Kuhry, P.: Estimated stocks of circumpolar permafrost carbon with quantified uncertainty ranges and identified data gaps, Biogeosciences, 11, 6573-6593, doi:10.5194/bg-11-6573-2014, 2014.

Ito, A.: A historical meta-analysis of global terrestrial net primary productivity: are estimates converging?, Glob. Change Biol., 17, 3161-3175, doi:10.1111/j.1365-2486.2011.02450.x, 2011.

Jarvis, P. G.: The Interpretation of the Variations in Leaf Water Potential and Stomatal Conductance Found in Canopies in the Field, Philos. T. R. Soc. B, 273, 593-610, doi:10.1098/rstb.1976.0035, 1976.

Jin, M. and Liang, S.: An Improved Land Surface Emissivity Parameter for Land Surface Models Using Global Remote Sensing Observations, J. Climate, 19, 2867-2881, doi:10.1175/JCLI3720.1, 2006.

Jordan, R.: A one-dimensional temperature model for a snow cover, technical documentation for SNTHERM, 89. U.S. Army Cold Regions Research and Engineering Laboratory, Special Report 91-16, 1991.

Jung, M., Reichstein, M., and Bondeau, A.: Towards global empirical upscaling of FLUXNET eddy covariance observations: validation of a model tree ensemble approach using a biosphere model, Biogeosciences, 6, 2001-2013, doi:10.5194/bg-62001-2009, 2009 (data available at: https://www.bgc-jena.mpg. de/geodb/projects/Data.php).

Jung, M., Reichstein, M., Margolis, H. A., Cescatti, A., Richardson, A. D., Arain, M. A., Arneth, A., Bernhofer, C., Bonal, D., Chen, J., Gianelle, D., Gobron, N., Kiely, G., Kutsch, W., Lasslop, G., Law, B. E., Lindroth, A., Merbold, L., Montagnani, L., Moors, E. J., Papale, D., Sottocornola, M., Vaccari, F., and Williams, C.: Global patterns of land-atmosphere fluxes of carbon dioxide, latent heat, and sensible heat derived from eddy covariance, satellite, and meteorological observations, J. Geophys. Res.-Biogeo., 116, 2-4, doi:10.1029/2010JG001566, 2011.

Kaplan, J. O., Prentice, I. C., and Buchmann, N.: The stable carbon isotope composition of the terrestrial biosphere: Modeling at scales from the leaf to the globe, Global Biogeochem. Cy., 16, 8-1-8-11, doi:10.1029/2001GB001403, 2002.

Kattge, J., Díaz, S., Lavorel, S., Prentice, I. C., Leadley, P., Bönisch, G., Garnier, E., Westoby, M., Reich, P. B., Wright, I. J., Cornelissen, J. H. C., Violle, C., Harrison, S. P., Van Bodegom, P. M., Reichstein, M., Enquist, B. J., Soudzilovskaia, N. A., Ackerly, D. D., Anand, M., Atkin, O., Bahn, M., Baker, T. R., Baldocchi, D., Bekker, R., Blanco, C. C., Blonder, B., Bond, W. J., Bradstock, R., Bunker, D. E., Casanoves, F., Cavender-Bares, J., Chambers, J. Q., Chapin, F. S., Chave, J., Coomes, D., Cornwell, W. K., Craine, J. M., Dobrin, B. H., Duarte, L., Durka, W., Elser, J., Esser, G., Estiarte, M., Fagan, W. F., Fang, J., FernándezMéndez, F., Fidelis, A., Finegan, B., Flores, O., Ford, H., Frank, D., Freschet, G. T., Fyllas, N. M., Gallagher, R. V., Green, W. A., Gutierrez, A. G., Hickler, T., Higgins, S. I., Hodgson, J. G., Jalili, A., Jansen, S., Joly, C. A., Kerkhoff, A. J., Kirkup, D., Kitajima, K., Kleyer, M., Klotz, S., Knops, J. M. H., Kramer, K., Kühn, I., Kurokawa, H., Laughlin, D., Lee, T. D., Leishman, M., Lens, F., Lenz, T., Lewis, S. L., Lloyd, J., Llusià, J., Louault, F., Ma, S., Mahecha, M. D., Manning, P., Massad, T., Medlyn, B. E., Messier, J., Moles, A. T., Müller, S. C., Nadrowski, K., Naeem, S., Niinemets, Ü., Nöllert, S., Nüske, A., Ogaya, R., Oleksyn, J., Onipchenko, V. G., Onoda, Y., Ordoñez, J., Overbeck, G., Ozinga, W. A., Patiño, S., Paula, S., Pausas, J. G., Peñuelas, J., Phillips, O. L., Pillar, V., Poorter, H., Poorter, L., Poschlod, P., Prinzing, A., Proulx, R., Rammig, A., Reinsch, S., Reu, B., Sack, L., Salgado-Negret, B., Sardans, J., Shiodera, S., Shipley, B., Siefert, A., Sosinski, E., Soussana, J. F., Swaine, E., Swenson, N., Thompson, K., Thornton, P., Waldram, M., Weiher, E., White, M., White, S., Wright, S. J., Yguel, B., Zaehle, S., Zanne, A. E., and Wirth, C.: TRY - a global database of plant traits, Glob. Change Biol., 17, 2905-2935, doi:10.1111/j.13652486.2011.02451.x, 2011.

Keeling, C. D., Bacastow, R. B., Bainbridge, A. E., Ekdahl Jr., C. A., Guenther, P. R., Waterman, L. S., and Chin, J. F. S.: Atmospheric carbon dioxide variations at Mauna Loa Observatory, Hawaii, Tellus A, 28, 538-551, doi:10.3402/tellusa.v28i6.11322, 1976 (data available at: http://www.esrl.noaa.gov/gmd/ccgg/trends/ full.html).

Khvorostyanov, D. V., Krinner, G., Ciais, P., Heimann, M., and Zimov, S. A.: Vulnerability of permafrost carbon to global warming. Part I: model description and role of heat generated by organic matter decomposition, Tellus B, 60, 250-264, doi:10.1111/j.1600-0889.2007.00333.x, 2008. 
Kleinen, T., Brovkin, V., and Schuldt, R. J.: A dynamic model of wetland extent and peat accumulation: results for the Holocene, Biogeosciences, 9, 235-248, doi:10.5194/bg-9-235-2012, 2012.

Kojima, K.: Densification of seasonal snow cover, in: Proc. Internat. Conf. Physics Snow Ice, Hokkaido University, Sapporo, Japan, 929-952, 1967.

Koven, C., Friedlingstein, P., Ciais, P., Khvorostyanov, D., Krinner, G., and Tarnocai, C.: On the formation of high-latitude soil carbon stocks: Effects of cryoturbation and insulation by organic matter in a land surface model, Geophys. Res. Lett., 36, L21501, doi:10.1029/2009GL040150, 2009.

Koven, C. D., Riley, W. J., Subin, Z. M., Tang, J. Y., Torn, M. S., Collins, W. D., Bonan, G. B., Lawrence, D. M., and Swenson, S. C.: The effect of vertically resolved soil biogeochemistry and alternate soil $\mathrm{C}$ and $\mathrm{N}$ models on C dynamics of CLM4, Biogeosciences, 10, 7109-7131, doi:10.5194/bg-10-7109-2013, 2013.

Krinner, G., Viovy, N., de Noblet-Ducoudré, N., Ogée, J., Polcher, J., Friedlingstein, P., Ciais, P., Sitch, S., and Prentice, I. C.: A dynamic global vegetation model for studies of the coupled atmosphere-biosphere system, Global Biogeochem. Cy., 19, GB1015, doi:10.1029/2003GB002199, 2005.

Lasslop, G., Thonicke, K., and Kloster, S.: SPITFIRE within the MPI Earth system model: Model development and evaluation, Journal of Advances in Modeling Earth Systems, 6, 740-755, doi:10.1002/2013MS000284, 2014.

Lawrence, D. M. and Slater, A. G.: Incorporating organic soil into a global climate model, Clim. Dynam., 30, 145-160, doi:10.1007/s00382-007-0278-1, 2008.

Lee, T. J. and Pielke, R. A.: Estimating the Soil Surface Specific Humidity, J. Appl. Meteor, 31, 480-484, doi:10.1175/15200450(1992)031<0480:ETSSSH>2.0.CO;2, 1992.

Letts, M. G., Roulet, N. T., Comer, N. T., Skarupa, M. R., and Verseghy, D. L.: Parametrization of peatland hydraulic properties for the Canadian land surface scheme, Atmos. Ocean, 38, 141-160, doi:10.1080/07055900.2000.9649643, 2000.

Leuning, R.: A critical appraisal of a combined stomatalphotosynthesis model for C3 plants, Plant Cell Environ., 18, 339-355, doi:10.1111/j.1365-3040.1995.tb00370.x, 1995.

Lin, Y.-S., Medlyn, B. E., Duursma, R. A., Prentice, I. C., Wang, H., Baig, S., Eamus, D., de Dios, V., Mitchell, P., Ellsworth, D. S., de Beeck, M. O., Wallin, G., Uddling, J., Tarvainen, L., Linderson, M.-L., Cernusak, L. A., Nippert, J. B., Ocheltree, T. W., Tissue, D. T., Martin-StPaul, N. K., Rogers, A., Warren, J. M., De Angelis, P., Hikosaka, K., Han, Q., Onoda, Y., Gimeno, T. E., Barton, C. V. M., Bennie, J., Bonal, D., Bosc, A., Löw, M., Macinins-Ng, C., Rey, A., Rowland, L., Setterfield, S. A., TauszPosch, S., Zaragoza-Castells, J., Broadmeadow, M. S. J., Drake, J. E., Freeman, M., Ghannoum, O., Hutley, L., Kelly, J. W., Kikuzawa, K., Kolari, P., Koyama, K., Limousin, J.-M., Meir, P., Lola da Costa, A. C., Mikkelsen, T. N., Salinas, N., Sun, W., and Wingate, L.: Optimal stomatal behaviour around the world, Nature Climate Change, 5, 459-464, doi:10.1038/nclimate2550, 2015.

Liu, Y., Dorigo, W., Parinussa, R., de Jeu, R., Wagner, W., McCabe, M., Evans, J., and van Dijk, A.: Trend-preserving blending of passive and active microwave soil moisture retrievals, Remote Sens. Environ., 123, 280-297, doi:10.1016/j.rse.2012.03.014, 2012 (data available at: http://www.esa-soilmoisture-cci.org/ node/145).
Lloyd, J. and Farquhar, G. D.: ${ }^{13} \mathrm{C}$ discrimination during $\mathrm{CO}_{2}$ assimilation by the terrestrial biosphere, Oecologia, 99, 201-215, doi:10.1007/BF00627732, 1994.

Lloyd, J. and Taylor, J. A.: On the temperature dependence of soil respiration, British Ecological Society, 8, 315-323, doi:10.2307/2389824, 1994.

Luojus, K., Pulliainen, J., and Consortiuum, G.: Global Snow Monitoring for Climate Research: Snow Water Equivalent, available at: http://www.globsnow.info/swe/ (last access: 10 January 2016), 2013.

Mahfouf, J. F. and Noilhan, J.: Comparative Study of Various Formulations of Evaporations from Bare Soil Using In Situ Data, J. Appl. Meteorol., 30, 1354-1365, doi:10.1175/15200450(1991)030<1354:CSOVFO>2.0.CO;2, 1991.

Malmer, N. and Wallén, B.: Input rates, decay losses and accumulation rates of carbon in bogs during the last millennium: internal processes and environmental changes, The Holocene, 14, 111117, doi:10.1191/0959683604hl693rp, 2004.

Manabe, S.: Climate and the ocean circulation I. The atmosphere and the hydrology of the Earth's surface, Mon. Weather Rev., 97, 739-774, doi:10.1175/15200493(1969)097<0739:CATOC>2.3.CO;2, 1969.

Medlyn, B. E., Duursma, R. A., Eamus, D., Ellsworth, D. S., Prentice, I. C., Barton, C. V. M., Crous, K. Y., De Angelis, P., Freeman, M., and Wingate, L.: Reconciling the optimal and empirical approaches to modelling stomatal conductance, Glob. Change Biol., 17, 2134-2144, doi:10.1111/j.1365-2486.2010.02375.x, 2011.

Melack, J. M. and Hess, L. L.: Remote sensing of the distribution and extent of wetlands in the Amazon basin, in: Amazonian floodplain forests: Ecophysiology, ecology, biodiversity and sustainable management, edited by: Junk, W. J., Piedade, M. T., Wittmann, F., Schöngart, J., and Parolin, P., Springer, doi:10.1007/978-90-481-8725-6_3, available at: http: //link.springer.com/10.1007/978-90-481-8725-6_3, 2010.

Melillo, J. M., McGuire, A. D., Kicklighter, D. W., Moore, B., Vorosmarty, C. J., and Schloss, A. L.: Global climate change and terrestrial net primary production, Nature, 363, 234-240, doi:10.1038/363234a0, 1993.

Milly, P. C. D. and Shmakin, A. B.: Global Modeling of Land Water and Energy Balances. Part I: The Land Dynamics (LaD) Model, J. Hydrometeorol., 3, 283-299, doi:10.1175/15257541(2002)003<0283:GMOLWA>2.0.CO;2, 2002.

Moody, E. G., King, M. D., Schaaf, C. B., Hall, D. K., and Platnick, S.: Northern Hemisphere five-year average (2000-2004) spectral albedos of surfaces in the presence of snow: Statistics computed from Terra MODIS land products, Remote Sens. Environ., 111, 337-345, doi:10.1016/j.rse.2007.03.026, 2007.

Mueller, B., Hirschi, M., Jimenez, C., Ciais, P., Dirmeyer, P. A., Dolman, A. J., Fisher, J. B., Jung, M., Ludwig, F., Maignan, F., Miralles, D. G., McCabe, M. F., Reichstein, M., Sheffield, J., Wang, K., Wood, E. F., Zhang, Y., and Seneviratne, S. I.: Benchmark products for land evapotranspiration: LandFlux-EVAL multi-data set synthesis, Hydrol. Earth Syst. Sci., 17, 3707-3720, doi:10.5194/hess-17-37072013, 2013 (data available at: http://www.iac.ethz.ch/group/ land-climate-dynamics/research/landflux-eval.html).

Murray-Tortarolo, G., Anav, A., Friedlingstein, P., Sitch, S., Piao, S., Zhu, Z., Poulter, B., Zaehle, S. S., Ahlström, A., Lomas, 
M., Levis, S., Viovy, N., and Zeng, N.: Evaluation of land surface models in reproducing satellite-derived LAI over the highlatitude northern hemisphere. Part I: Uncoupled DGVMs, Remote Sensing, 5, 4819-4838, doi:10.3390/rs5104819, 2013.

Neilson, R. P.: A Model for Predicting Continental-Scale Vegetation Distribution and Water Balance, Ecol. Appl., 5, 362, doi:10.2307/1942028, 1995.

Niu, G.-Y. and Yang, Z.-L.: Effects of Frozen Soil on Snowmelt Runoff and Soil Water Storage at a Continental Scale, J. Hydrometeorol., 7, 937-952, doi:10.1175/JHM538.1, 2006.

Niu, G.-Y., Yang, Z.-L., Dickinson, R. E., and Gulden, L. E.: A simple TOPMODEL-based runoff parameterization (SIMTOP) for use in global climate models, J. Geophys. Res., 110, D21106, doi:10.1029/2005JD006111, 2005.

Oleson, K., Bonan, G., Levis, S., Thornton, P., Vertenstein, M., and Yang, Z.: Technical Description of the Community Land Model (CLM), NCAR Technical Note, 461, 1-174, doi:10.5065/D6N877R0, 2004.

Oleson, K. W., Lawrence, D. M., Bonan, G. B., Drewniak, B., Huang, M., Charles, D., Levis, S., Li, F., Riley, W. J., Zachary, M., Swenson, S. C., Thornton, P. E., Bozbiyik, A., Fisher, R., Heald, C. L., Kluzek, E., Lamarque, F., Lawrence, P. J., Leung, L. R., Muszala, S., Ricciuto, D. M., Sacks, W., Sun, Y., Tang, J., and Yang, Z.-L.: Technical Description of version 4.5 of the Community Land Model (CLM) Coordinating, Tech. Rep. July, 2013.

Otto, J., Raddatz, T., and Claussen, M.: Strength of forest-albedo feedback in mid-Holocene climate simulations, Clim. Past, 7, 1027-1039, doi:10.5194/cp-7-1027-2011, 2011.

Papa, F., Prigent, C., Aires, F., Jimenez, C., Rossow, W. B., and Matthews, E.: Interannual variability of surface water extent at the global scale, 1993-2004, J. Geophys. Res., 115, D12111, doi:10.1029/2009JD012674, 2010.

Petoukhov, V., Ganopolski, A., Brovkin, V., Claussen, M., Eliseev, A., Kubatzki, C., and Rahmstorf, S.: CLIMBER-2: a climate system model of intermediate complexity. Part I: model description and performance for present climate, Clim. Dynam., 16, 1-17, doi:10.1007/PL00007919, 2000.

Pitman, A. J.: The evolution of, and revolution in, land surface schemes designed for climate models, Int. J. Climatol., 23, 479510, doi:10.1002/joc.893, 2003.

Pitman, A. J., Liang, Z. L., Cogley, J. G., and Henderson-Sellers, A.: Description of bare essentials of surface transfer for the Bureau of Meteorological Research Centre AGCM, Tech. rep., 1991.

Porporato, A., D’Odorico, P., Laio, F., and Rodriguez-Iturbe, I.: Hydrologic controls on soil carbon and nitrogen cycles. I. Modeling scheme, Adv. Water Resour., 26, 45-58, doi:10.1016/S03091708(02)00094-5, 2003.

Prentice, I. C., Cramer, W., Harrison, S. P., Leemans, R., Robert, A., Solomon, A. M., and Vallgatan, O.: A global biome model based on plant physiology and dominance, soil properties and climate, J. Biogeogr., 19, 117-134, 1992.

Prentice, I. C., Farquhar, G. D., Fasham, M. J. R., Goulden, M. L., Heimann, M., Jaramillo, W. J., Kheshgi, H. S., Le Quéré, C., Scholes, R. J., and Wallace, D. W. R.: Climate Change 2001. The Science Basis. Contribution of Working Group I to the Third Assessment Report of the Intergovernmental Panel on Climate Change, in: The Carbon Cycle and Atmospheric Carbon Dioxide Content, edited by: Houghton, J. T., Ding, Y., Griggs, D.
J., Noguer, M., van der Linden, P. J., Dai, X., Maskell, K., and Johnson, C. A., Cambridge University Press, Cambridge, United Kingdom, 2001.

Prigent, C., Papa, F., Aires, F., Rossow, W. B., and Matthews, E.: Global inundation dynamics inferred from multiple satellite observations, 1993-2000, J. Geophys. Res., 112, D12107, doi:10.1029/2006JD007847, 2007.

Raich, J. W., Rastetter, E. B., Melillo, J. M., Kicklighter, D. W., Steudler, P. A., Peterson, B. J., Grace, A. L., Moore III, B., and Vorosmarty, C. J.: Potential Net Primary Productivity in South America: Application of a Global Model, Ecol. Appl., 1, 399 , doi:10.2307/1941899, 1991.

Ramankutty, N. and Foley, J. A.: Estimating historical changes in global land cover: Croplands from 1700 to 1992, Global Biogeochem. Сy., 13, 997-1027, doi:10.1029/1999GB900046, 1999.

Reick, C. H., Raddatz, T., Brovkin, V., and Gayler, V.: Representation of natural and anthropogenic land cover change in MPIESM, Journal of Advances in Modeling Earth Systems, 5, 459482, doi:10.1002/jame.20022, 2013.

Riche, F. and Schneebeli, M.: Thermal conductivity of snow measured by three independent methods and anisotropy considerations, The Cryosphere, 7, 217-227, doi:10.5194/tc-7-217-2013, 2013.

Riley, W. J., Subin, Z. M., Lawrence, D. M., Swenson, S. C., Torn, M. S., Meng, L., Mahowald, N. M., and Hess, P.: Barriers to predicting changes in global terrestrial methane fluxes: analyses using CLM4Me, a methane biogeochemistry model integrated in CESM, Biogeosciences, 8, 1925-1953, doi:10.5194/bg-8-19252011, 2011.

Rinke, A., Kuhry, P., and Dethloff, K.: Importance of a soil organic layer for Arctic climate: A sensitivity study with an Arctic RCM, Geophys. Res. Lett., 35, L13709, doi:10.1029/2008GL034052, 2008.

Robinson, A. and Perrette, M.: NCIO 1.0: a simple Fortran NetCDF interface, Geosci. Model Dev., 8, 1877-1883, doi:10.5194/gmd8-1877-2015, 2015.

Running, S. W. and Coughlan, J. C.: A general model of forest ecosystem processes for regional applications I. Hydrologic balance, canopy gas exchange and primary production processes, Ecol. Model., 42, 125-154, doi:10.1016/0304-3800(88)90112-3, 1988.

Running, S. W. and Gower, S. T.: FOREST-BGC, A general model of forest ecosystem processes for regional applications. II. Dynamic carbon allocation and nitrogen budgets, Tree Physiol., 9, 147-160, 1991.

Sato, H., Itoh, A., and Kohyama, T.: SEIB-DGVM: A new Dynamic Global Vegetation Model using a spatially explicit individual-based approach, Ecol. Model., 200, 279-307, doi:10.1016/j.ecolmodel.2006.09.006, 2007.

Schaaf, C. and Wang, Z.: MCD43C3 MODIS/Terra+Aqua BRDF/Albedo Albedo Daily L3 Global 0.05Deg CMG V006, http://doi.org/10.5067/MODIS/MCD43C3.006 (last access: 21 February 2016), 2015 (data available at: doi:10.5067/MODIS/MCD43C3.006).

Schaphoff, S., Heyder, U., Ostberg, S., Gerten, D., Heinke, J., and Lucht, W.: Contribution of permafrost soils to the global carbon budget, Environ. Res. Lett., 8, 014026, doi:10.1088/17489326/8/1/014026, 2013. 
Schneider, U., Becker, A., Finger, P., Meyer-Christoffer, A., Ziese, M., and Rudolf, B.: GPCC's new land surface precipitation climatology based on quality-controlled in situ data and its role in quantifying the global water cycle, Theor. Appl. Climatol., 115, 15-40, doi:10.1007/s00704-013-0860-x, 2014 (data available at: http://gpcc.dwd.de).

Scholze, M., Kaplan, J. O., Knorr, W., and Heimann, M.: Climate and interannual variability of the atmospherebiosphere ${ }^{13} \mathrm{CO}_{2}$ flux, Geophys. Res. Lett., 30, 1097, doi:10.1029/2002GL015631, 2003.

Schuur, E. A. G., McGuire, A. D., Schädel, C., Grosse, G., Harden, J. W., Hayes, D. J., Hugelius, G., Koven, C. D., Kuhry, P., Lawrence, D. M., Natali, S. M., Olefeldt, D., Romanovsky, V. E., Schaefer, K., Turetsky, M. R., Treat, C. C., and Vonk, J. E.: Climate change and the permafrost carbon feedback, Nature, 520, 171-179, doi:10.1038/nature14338, 2015.

Sellers, P. J., Mintz, Y., Sud, Y. C., and Dalcher, A.: A Simple Biosphere Model (SIB) for Use within General Circulation Models, J. Atmos. Sci., 43, 505-531, doi:10.1175/15200469(1986)043<0505:ASBMFU>2.0.CO;2, 1986.

Sellers, P. J., Dickinson, R. E., Randall, D. A., Betts, A. K., Hall, F. G., Berry, J. A., Collatz, G. J., Denning, A. S., Mooney, H. A., Nobre, C. A., Sato, N., Field, C. B., and Henderson-Sellers, A.: Modeling the Exchanges of Energy, Water, and Carbon Between Continents and the Atmosphere, Science, 275, 502-509, doi:10.1126/science.275.5299.502, 1997.

Shangguan, W., Dai, Y., Duan, Q., Liu, B., and Yuan, H.: A global soil data set for earth system modeling, Journal of Advances in Modeling Earth Systems, 6, 249-263, doi:10.1002/2013MS000293, 2014.

Shi, H. X. and Wang, C. H.: Projected 21st century changes in snow water equivalent over Northern Hemisphere landmasses from the CMIP5 model ensemble, The Cryosphere, 9, 19431953, doi:10.5194/tc-9-1943-2015, 2015.

Sitch, S., Smith, B., Prentice, I. C., Arneth, A., Bondeau, A., Cramer, W., Kaplan, J. O., Levis, S., Lucht, W., Sykes, M. T., Thonicke, K., and Venevsky, S.: Evaluation of ecosystem dynamics, plant geography and terrestrial carbon cycling in the LPJ dynamic global vegetation model, Glob. Change Biol., 9, 161-185, doi:10.1046/j.1365-2486.2003.00569.x, 2003.

Spahni, R., Wania, R., Neef, L., van Weele, M., Pison, I., Bousquet, P., Frankenberg, C., Foster, P. N., Joos, F., Prentice, I. C., and van Velthoven, P.: Constraining global methane emissions and uptake by ecosystems, Biogeosciences, 8, 1643-1665, doi:10.5194/bg8-1643-2011, 2011.

Spahni, R., Joos, F., Stocker, B. D., Steinacher, M., and Yu, Z. C.: Transient simulations of the carbon and nitrogen dynamics in northern peatlands: from the Last Glacial Maximum to the 21st century, Clim. Past, 9, 1287-1308, doi:10.5194/cp-9-1287-2013, 2013.

Stocker, B. D., Spahni, R., and Joos, F.: DYPTOP: a costefficient TOPMODEL implementation to simulate sub-grid spatio-temporal dynamics of global wetlands and peatlands, Geosci. Model Dev., 7, 3089-3110, doi:10.5194/gmd-7-30892014, 2014.

Takala, M., Luojus, K., Pulliainen, J., Derksen, C., Lemmetyinen, J., Kärnä, J. P., Koskinen, J., and Bojkov, B.: Estimating northern hemisphere snow water equivalent for climate research through assimilation of space-borne radiometer data and ground- based measurements, Remote Sens. Environ., 115, 3517-3529, doi:10.1016/j.rse.2011.08.014, 2011.

Tarnocai, C., Canadell, J. G., Schuur, E. A. G., Kuhry, P., Mazhitova, G., and Zimov, S.: Soil organic carbon pools in the northern circumpolar permafrost region, Global Biogeochem. Cy., 23, GB2023, doi:10.1029/2008GB003327, 2009.

Thonicke, K., Spessa, A., Prentice, I. C., Harrison, S. P., Dong, L., and Carmona-Moreno, C.: The influence of vegetation, fire spread and fire behaviour on biomass burning and trace gas emissions: results from a process-based model, Biogeosciences, 7, 1991-2011, doi:10.5194/bg-7-1991-2010, 2010.

Todd-Brown, K. E. O., Randerson, J. T., Post, W. M., Hoffman, F. M., Tarnocai, C., Schuur, E. A. G., and Allison, S. D.: Causes of variation in soil carbon simulations from CMIP5 Earth system models and comparison with observations, Biogeosciences, 10, 1717-1736, doi:10.5194/bg-10-1717-2013, 2013.

Trenberth, K. E., Smith, L., Qian, T., Dai, A., and Fasullo, J.: Estimates of the Global Water Budget and Its Annual Cycle Using Observational and Model Data, J. Hydrometeorol., 8, 758-769, doi:10.1175/JHM600.1, 2007.

Turunen, J., Tomppo, E., Tolonen, K., and Reinikainen, A.: Estimating carbon accumulation rates of undrained mires in Finland - application to boreal and subarctic regions, The Holocene, 12, 69-80, doi:10.1191/0959683602hl522rp, 2002.

Uppala, S. M., Kallberg, P. W., Simmons, A. J., Andrae, U., Bechtold, V. D. C., Fiorino, M., Gibson, J. K., Haseler, J., Hernandez, A., Kelly, G. A., Li, X., Onogi, K., Saarinen, S., Sokka, N., Allan, R. P., Andersson, E., Arpe, K., Balmaseda, M. A., Beljaars, A. C. M., Berg, L. V. D., Bidlot, J., Bormann, N., Caires, S., Chevallier, F., Dethof, A., Dragosavac, M., Fisher, M., Fuentes, M., Hagemann, S., Hólm, E., Hoskins, B. J., Isaksen, L., Janssen, P. A. E. M., Jenne, R., Mcnally, A. P., Mahfouf, J.-F., Morcrette, J.-J., Rayner, N. A., Saunders, R. W., Simon, P., Sterl, A., Trenberth, K. E., Untch, A., Vasiljevic, D., Viterbo, P., and Woollen, J.: The ERA-40 re-analysis, Q. J. Roy. Meteor. Soc., 131, 29613012, doi:10.1256/qj.04.176, 2005.

Verseghy, D. L., McFarlane, N. A., and Lazare, M.: Class - A Canadian land surface scheme for GCMS, II. Vegetation model and coupled runs, Int. J. Climatol., 13, 347-370, doi:10.1002/joc.3370130402, 1993.

Wagner, W., Dorigo, W., de Jeu, R., Fernandez, D., Benveniste, J., Haas, E., and Ertl, M.: Fusion of Active and Passive Microwave Observations To Create an Essential Climate Variable Data Record on Soil Moisture, ISPRS Annals of Photogrammetry, Remote Sensing and Spatial Information Sciences, I-7, 315321, doi:10.5194/isprsannals-I-7-315-2012, 2012 (data available at: http://www.esa-soilmoisture-cci.org/node/145).

Walters, D. N., Williams, K. D., Boutle, I. A., Bushell, A. C., Edwards, J. M., Field, P. R., Lock, A. P., Morcrette, C. J., Stratton, R. A., Wilkinson, J. M., Willett, M. R., Bellouin, N., BodasSalcedo, A., Brooks, M. E., Copsey, D., Earnshaw, P. D., Hardiman, S. C., Harris, C. M., Levine, R. C., MacLachlan, C., Manners, J. C., Martin, G. M., Milton, S. F., Palmer, M. D., Roberts, M. J., Rodríguez, J. M., Tennant, W. J., and Vidale, P. L.: The Met Office Unified Model Global Atmosphere 4.0 and JULES Global Land 4.0 configurations, Geosci. Model Dev., 7, 361-386, doi:10.5194/gmd-7-361-2014, 2014.

Wania, R., Ross, I., and Prentice, I. C.: Integrating peatlands and permafrost into a dynamic global vegetation 
model: 2. Evaluation and sensitivity of vegetation and carbon cycle processes, Global Biogeochem. Cy., 23, GB3015, doi:10.1029/2008GB003413, 2009.

Warren, S. G. and Wiscombe, W. J.: A Model for the Spectral Albedo of Snow. I: Pure Snow, J. Atmos. Sci., 37, 2712-2733, doi:10.1175/15200469(1980)037\%3C2712:AMFTSA\%3E2.0.CO;2, 1980.

Watanabe, K. and Mizoguchi, M.: Amount of unfrozen water in frozen porous media saturated with solution, Cold Reg. Sci. Technol., 34, 103-110, doi:10.1016/S0165-232X(01)00063-5, 2002.

Weedon, G. P., Gomes, S., Viterbo, P., Shuttleworth, W. J., Blyth, E., Österle, H., Adam, J. C., Bellouin, N., Boucher, O., and Best, M.: Creation of the WATCH Forcing Data and Its Use to Assess Global and Regional Reference Crop Evaporation over Land during the Twentieth Century, J. Hydrometeorol., 12, 823-848, doi:10.1175/2011JHM1369.1, 2011.

Weedon, G., Balsamo, G., Bellouin, N., Gomes, S., Best, M., and Viterbo, P.: Data methodology applied to ERAInterim reanalysis data, Water Resour. Res., 50, 7505-7514, doi:10.1002/2014WR015638, 2014.

Willeit, M. and Ganopolski, A.: Coupled Northern Hemisphere permafrost-ice-sheet evolution over the last glacial cycle, Clim. Past, 11, 1165-1180, doi:10.5194/cp-11-1165-2015, 2015.

Willeit, M., Ganopolski, A., Dalmonech, D., Foley, A. M., and Feulner, G.: Time-scale and state dependence of the carboncycle feedback to climate, Clim. Dynam., 42, 1699-1713, doi:10.1007/s00382-014-2102-z, 2014a.

Willeit, M., Ganopolski, A., and Feulner, G.: Asymmetry and uncertainties in biogeophysical climate - vegetation feedback over a range of $\mathrm{CO}_{2}$ forcings, Biogeosciences, 11, 17-32, doi:10.5194/bg-11-17-2014, 2014b.

Williams, P. and Smith, M.: The Frozen Earth: Fundamentals of Geocryology, Cambridge University Press, Cambridge, ISBN10: 0-521-36534-1, 306 pp., 1989.
Woodward, F. I.: Climate and plant distribution, Cambridge University Press, ISBN-13: 9780521282147, 1987.

Woodward, F. I., Lomas, M. R., and Betts, R. A.: Vegetation-climate feedbacks in a greenhouse world, Philos. T. R. Soc. B, 353, 29 39, doi:10.1098/rstb.1998.0188, 1998.

Yen, Y.: Review of thermal properties of snow, ice and sea ice, Rep. 81-10, U. S. Army Cold Reg. Res. and Eng. Lab. (CRREL), Hanover, N. H., 1981.

Yu, Z., Loisel, J., Brosseau, D. P., Beilman, D. W., and Hunt, S. J.: Global peatland dynamics since the Last Glacial Maximum, Geophys. Res. Lett., 37, L13402, doi:10.1029/2010GL043584, 2010.

Yuan, H., Dai, Y., Xiao, Z., Ji, D., and Shangguan, W.: Reprocessing the MODIS Leaf Area Index products for land surface and climate modelling, Remote Sens. Environ., 115, 11711187, doi:10.1016/j.rse.2011.01.001, 2011 (data available at: http://globalchange.bnu.edu.cn/research/lai/lai_download.jsp).

Zeng, X.: Global Vegetation Root Distribution for Land Modeling, J. Hydrometeorol., 2, 525-530, doi:10.1175/15257541(2001)002<0525:GVRDFL>2.0.CO;2, 2001.

Zeng, X. and Wang, A.: Consistent Parameterization of Roughness Length and Displacement Height for Sparse and Dense Canopies in Land Models, J. Hydrometeorol., 8, 730-737, doi:10.1175/JHM607.1, 2007.

Zeng, X., Zeng, X., and Barlage, M.: Growing temperate shrubs over arid and semiarid regions in the Community Land ModelDynamic Global Vegetation Model, Global Biogeochem. Cy., 22, GB3003, doi:10.1029/2007GB003014, 2008.

Zhu, D., Peng, S., Ciais, P., Zech, R., Krinner, G., Zimov, S., and Grosse, G.: Simulating soil organic carbon in yedoma deposits during the Last Glacial Maximum in a land surface model, Geophys. Res. Lett., 43, 5133-5142, doi:10.1002/2016GL068874, 2016. 